\title{
ESTRUTURA GENÉTICA EM POPULAÇÕES DE BRACATINGA (Mimosa scabrella Benth.) POR MARCADOR ISOENZIMÁTICO E CARACTERES QUANTITATIVOS
}

\author{
GRACIELA DA ROCHA SOBIERAJSKI
}

\author{
Dissertação apresentada à Escola Superior de \\ Agricultura "Luiz de Queiroz" Universidade de São \\ Paulo, para obtenção do título de Mestre em Recursos \\ Florestais, com opção em Conservação de \\ Ecossistemas Florestais.
}

P I R A C I C A B A

Estado de São Paulo - Brasil

Setembro - 2004 


\title{
ESTRUTURA GENÉTICA EM POPULAÇÕES DE BRACATINGA (Mimosa scabrella Benth.) POR MARCADOR ISOENZIMÁTICO E CARACTERES QUANTITATIVOS
}

\section{GRACIELA DA ROCHA SOBIERAJSKI}

Licenciado em Ciências Biológicas

Orientador: Prof. Dr. PAULO YOSHIO KAGEYAMA

\author{
Dissertação apresentada à Escola Superior de \\ Agricultura "Luiz de Queiroz" Universidade de São \\ Paulo, para obtenção do título de Mestre em Recursos \\ Florestais, com opção em Conservação de \\ Ecossistemas Florestais.
}

P I R A C I C A B A Estado de São Paulo - Brasil

Setembro - 2004 


\section{Dados Internacionais de Catalogação na Publicação (CIP) DIVISÃO DE BIBLIOTECA E DOCUMENTAÇÃO - ESALQ/USP}

\section{Sobierajski, Graciela da Rocha}

Estrutura genética em populações de bracatinga (Minosa scabrella Bent.) por marcador isoenzimático e caracteres quantitativos / Graciela da Rocha Sobierajski. - Piracicaba, 2004.

128 p. : il.

Dissertação (mestrado) - - Escola Superior de Agricultura Luiz de Queiroz, 2004. Bibliografia.

1. Bracatinga 2. Diversidade genética 3. Genética de populações 4. Marcador molecular 5. Melhoramento genético vegetal 6 . Reprodução vegetal 7 . Variação genética em plantas I. Título

CDD 634.973321 
Aos meus pais, Leonardo e Ivone, pelo amor e pela oportunidade de sempre buscar a melhor formação pessoal e acadêmica, dedico.

Ao Marcio pelo amor, paciência e dedicação, ofereço. 


\section{AGRADECIMENTOS}

Essa Dissertação é fruto de um trabalho que teve seu início em Fevereiro de 2002 e, sem ajuda de várias pessoas, não seria possível concretizá-la com tamanha satisfação. De essa forma desejo agradecer às pessoas que de forma direta, ou indireta, contribuíram para minha formação. Assim agradeço:

Ao Prof. Paulo Yoshio Kageyama, pela orientação, pela amizade, pelo conhecimento e, principalmente pelo apoio e por acreditar nesse trabalho;

Ao pesquisador do Instituto Florestal Alexandre Magno Sebbenn, pelo apoio e dedicação em todas as fases desse trabalho, sempre com uma palavra de incentivo; e a sua esposa Rita, pelo carinho e hospitalidade;

Ao pesquisador da EMBRAPA/CNPF Antônio Aparecido Carpanezzi, pela disponibilização das sementes utilizadas na instalação do teste de procedências e progênies;

Aos pesquisadores Alexandre Magno Sebbenn, Mário Luiz Teixeira de Moraes e Maria Beatriz Perecin pelas valorosas contribuições na banca de qualificação;

Aos funcionários da Estação Experimental de Itatinga, por tornar possível a instalação do experimento e pela amizade;

À equipe técnica do LARGEA, Elza, Andréia, Gelson e Gabriela, pelo auxílio no laboratório e pelas horas de conversa;

Aos amigos pós-graduando do LARGEA, principalmente aos que dividiram as horas tensas de laboratório, sempre com alegria. Um agradecimento especial à Karina pela paciência de ler o protótipo da dissertação, e ao Luciano pelo auxílio na leitura dos 
géis;

Aos funcionários do IPEF (setor de informática) Rogério, Ivo, Evandro e Ricardo;

Aos professores que transmitiram seus conhecimentos com amor e dedicação;

Às bibliotecárias Silvia Maria Zinsly e Eliana Maria Garcia (Biblioteca central), e Marialice Poggiani (IPEF) pela sempre pronta disposição e simpatia;

Ao Conselho Nacional de Desenvolvimento Científico e Tecnológico pela concessão da bolsa de mestrado;

À minha família por compreender minha ausência, principalmente à minha mãe que nas suas curtas férias em Piracicaba encontrou disposição para me acompanhar nos trabalhos de campo; ao Marcio pela ajuda na tabulação dos dados, correções no texto e nas referências bibliográficas, e pela paciência nas horas de tensão; à minha irmã Rafaela e à minha madrinha Nena pelo apoio incondicional;

Aos colegas dos programas de pós-graduação em Recursos Florestais e Genética e Melhoramento de Plantas pelas horas de estudo em grupo e pela convivência;

Finalmente, aos demais colegas, sempre presentes, muito obrigado. 


\section{SUMÁRIO}

\section{Página}

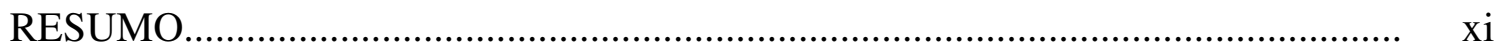

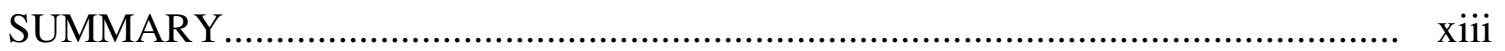

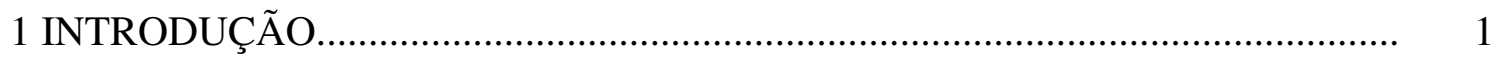

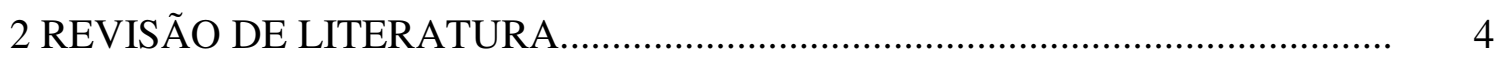

2.1 A Espécie Mimosa scabrella Benthan............................................................. 4

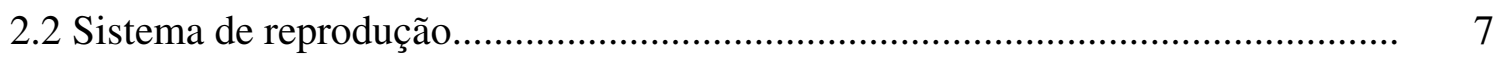

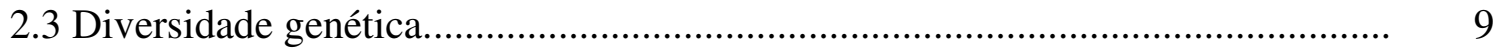

2.4 Variações genéticas por caracteres quantitativos e marcadores moleculares........ 10

3 ESTUDO PRELIMINAR DO SISTEMA DE REPRODUÇÃO EM NOVE PROCEDÊNCIAS DE Mimosa scabrella BENTHAN (LEGUMINOSACEAE).... 14

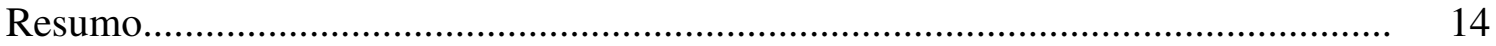

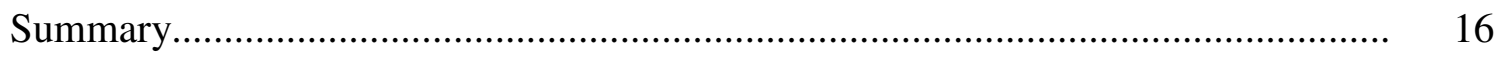

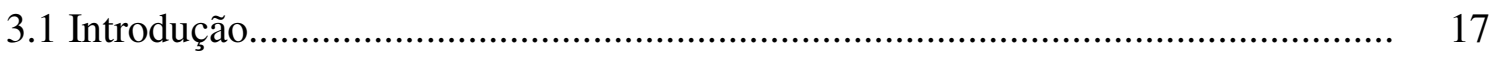

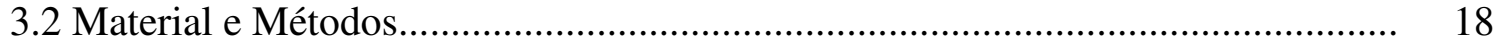

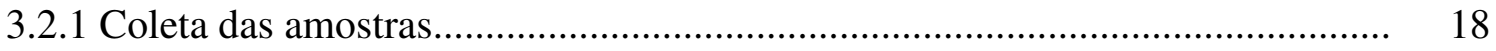

3.2.2 Eletroforese de isoenzimas................................................................. 21

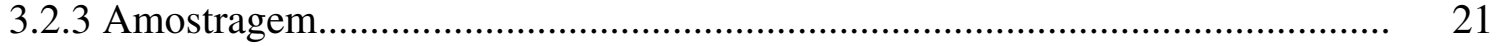

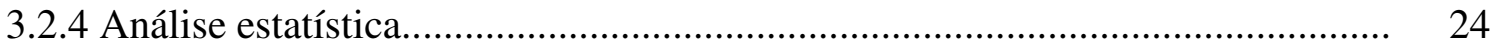

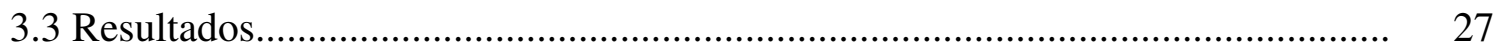

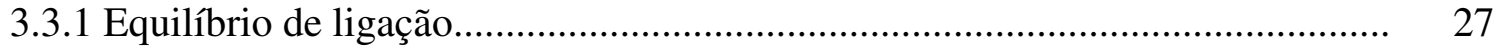

3.3.2 Freqüências alélicas do pólen e do óvulo................................................... 27 


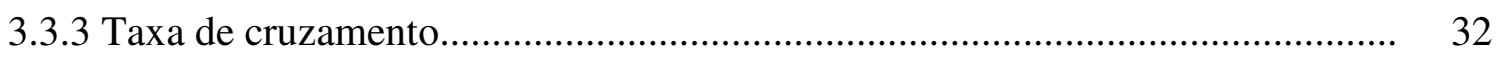

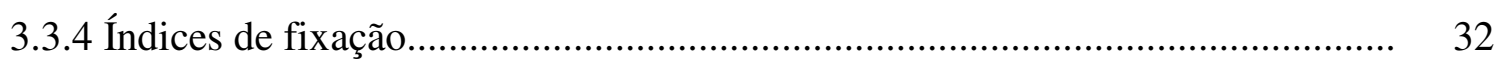

3.3.5 Cruzamentos correlacionados...................................................................... 33

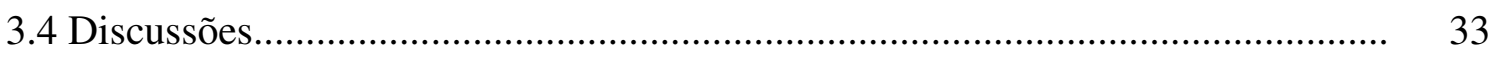

3.4.1 Equilíbrio de ligação............................................................................. 33

3.4.2 Freqüências alélicas do pólen e do óvulo....................................................... 34

3.4.3 Taxa de cruzamento............................................................................... 35

3.4.4 Cruzamento entre parentes..................................................................... 36

3.4.5 Taxa de cruzamentos correlacionados............................................................ 36

3.4.6 Índices de fixação................................................................................ 38

3.4.7 Coeficiente de coancestria e tamanho efetivo de variância................................. 38

4 DIVERSIDADE E ESTRUTURA GENÉTICA EM PROCEDÊNCIAS DE Mimosa scabrella BENTHAN DO BRASIL......................................................... 41

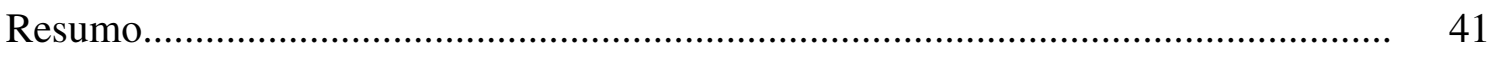

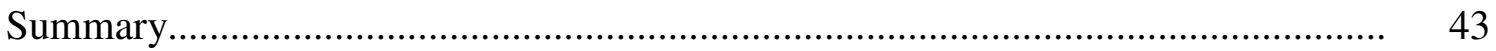

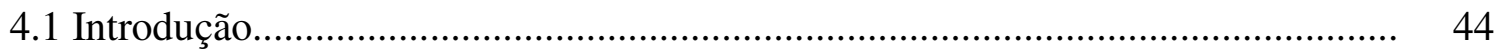

4.2 Material e Métodos...................................................................................... 45

4.2.1 Coleta das amostras................................................................................. 45

4.2.2 Eletroforese de isoenzimas........................................................................ 46

4.2.3 Análise dos dados................................................................................... 47

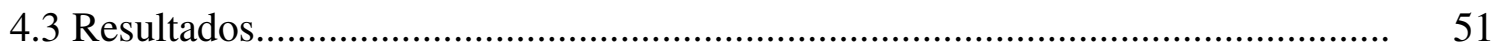

4.3.1 Freqüências alélicas................................................................................ 51

4.3.2 Equilíbrio de Hardy-Weinberg..................................................................... 52

4.3.3 Diversidade genética intrapopulacional........................................................... 53

4.3.4 Estrutura genética e índice de fixação................................................................ 57

4.3.5 Distâncias genéticas.................................................................................. 57

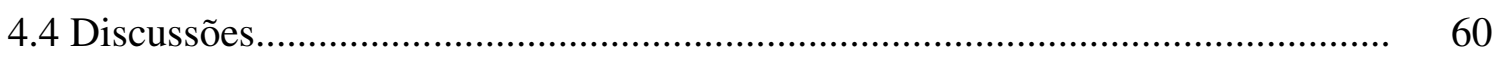

4.4.1 Equilíbrio de Hardy-Weinberg.................................................................. 60

4.4.2 Diversidade genética intrapopulacional............................................................ 61 


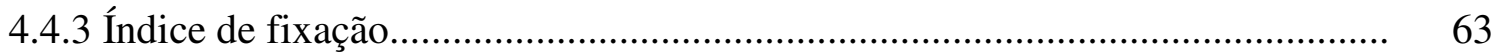

4.4.4 Estrutura genética e fluxo gênico................................................................. 64

5 VARIAÇÃO GENÉTICA ENTRE E DENTRO DE PROCEDÊNCIAS DE Mimosa scabrella BENTHAN POR CARACTERES QUANTITATIVOS E DADOS DE ISOENZIMAS........................................................................ 66

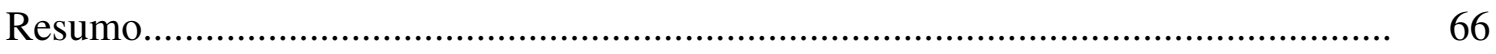

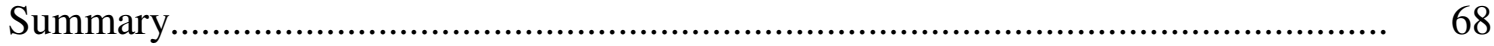

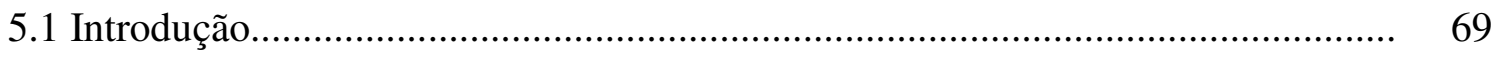

5.2 Material e Métodos........................................................................................ $\quad 70$

5.2.1 Áreas de coleta de sementes.......................................................................... 70

5.2.2 Amostragem e teste de procedências e progênies................................................. 71

5.2.3 Eletroforese de isoenzimas......................................................................... 71

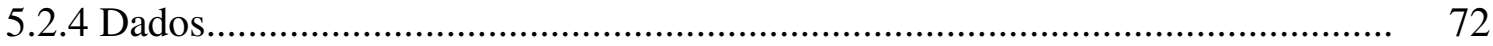

5.2.5 Análise dos dados de isoenzimas.............................................................. 72

5.2.6 Análise do caráter altura................................................................................ 73

a) Estimativa de componente da variância..............................................................

b) Estimativa de parâmetros genéticos....................................................................

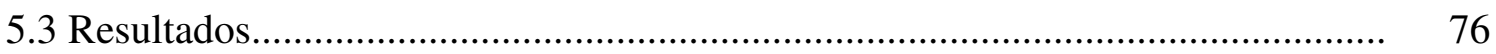

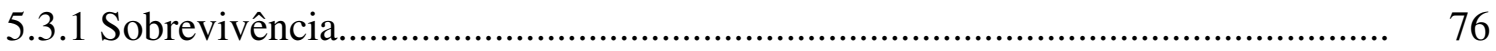

5.3.2 Crescimento em altura.................................................................................... 77

5.3.3 Análise de variância................................................................................ 77

5.3.4 Variação genética entre e dentro de procedências.................................................. 78

5.4 Discussões.................................................................................................. 79

5.4.1 Caracteres quantitativos........................................................................ 79

a) Sobrevivência.............................................................................................. 79

b) Crescimento em altura................................................................................. 80

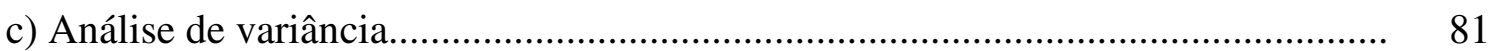

5.4.2 Variação genética entre e dentro de procedências por caracteres

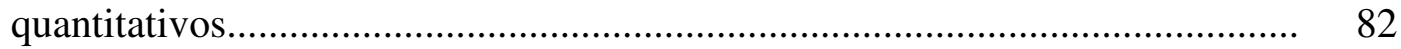


5.4.3 Variação genética entre e dentro de procedências por dados de isoenzimas.

5.4.4 Comparando a estrutura genética detectada por dados quantitativos com dados de isoenzimas.

6 ESTIMATIVAS DE PARÂMETROS GENÉTICOS EM POPULAÇÕES DE Mimosa scabrella BENTHAN USANDO OS MODELOS ALEATÓRIO E MISTO DE REPRODUÇÃO................................................................... 88

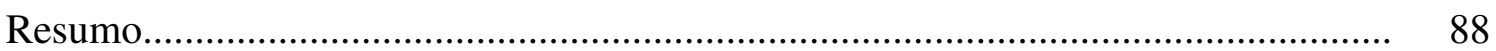

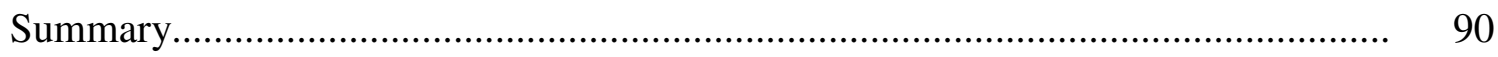

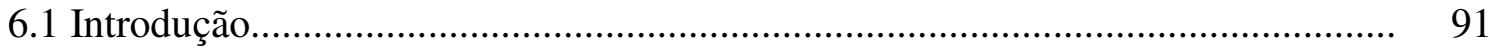

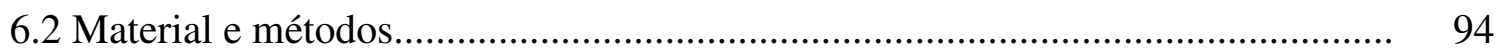

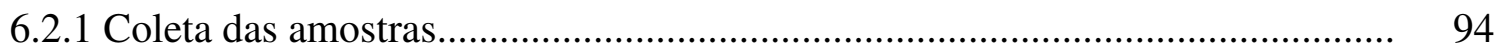

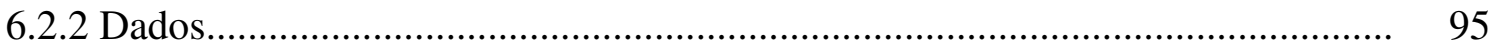

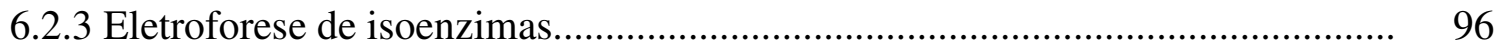

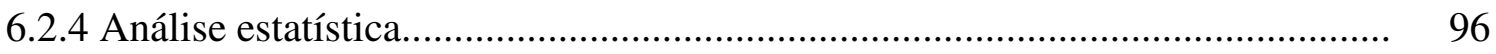

a) Parâmetros do sistema de reprodução................................................................ 96

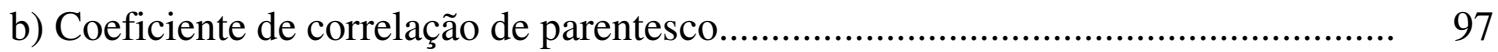

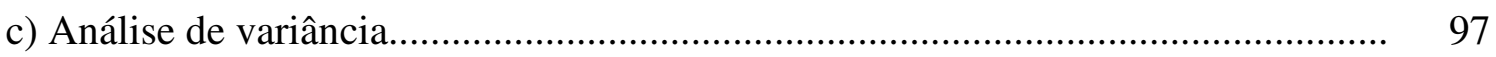

d) Variância genética aditiva........................................................................ 98

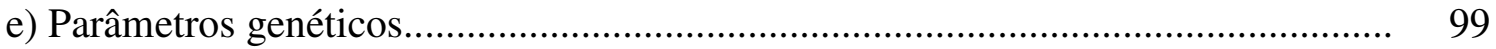

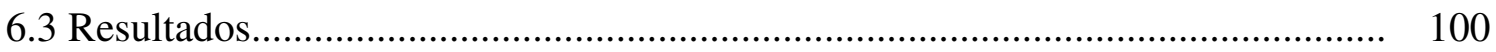

6.3.1 Parâmetros do sistema de reprodução e coeficiente de correlação de

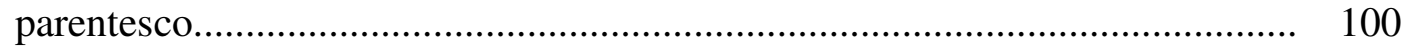

6.3.2 Análise de variância.............................................................................. 100

6.3.3 Componentes da variância.................................................................... 101

6.3.4 Parâmetros genéticos............................................................................... 102

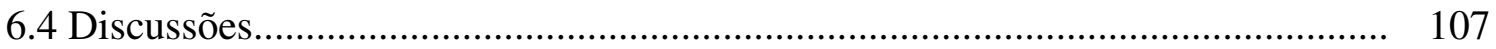

6.4.1 Parâmetros do sistema de reprodução e coeficiente de correlação de parentesco. 


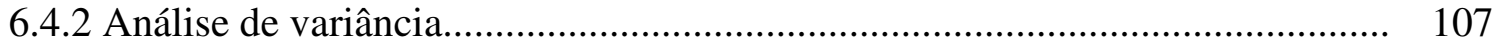

6.4.3 Coeficientes de variação....................................................................... 108

6.4.4 Variância genética aditiva................................................................... 109

6.4.5 Coeficientes de herdabilidade................................................................ 111

6.4.6 Ganhos na seleção........................................................................... 111

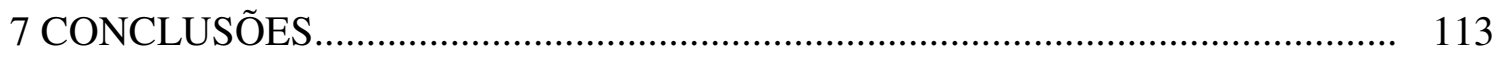

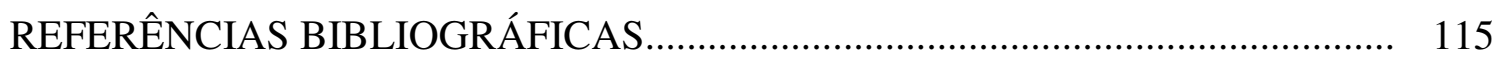




\title{
ESTRUTURA GENÉTICA EM POPULAÇÕES DE BRACATINGA (Mimosa scabrella Benth.) POR MARCADOR ISOENZIMÁTICO E CARACTERES QUANTITATIVOS
}

\author{
Autora: GRACIELA DA ROCHA SOBIERAJSKI \\ Orientador: PROF. DR. PAULO YOSHIO KAGEYAMA
}

\section{RESUMO}

A Mimosa scabrella Bentham (bracatinga) é uma espécie arbórea nativa da Mata Atlântica, de ocorrência restrita aos Estados do sul e sudeste do Brasil (RS, SC, PR, SP). A espécie vem sendo cultivada no sul do país e em outros países como Costa Rica e Ruanda, para os mais variados fins. Contudo, embora a espécie tenha diversas utilidades, muito pouco tem sido feito em termos de melhoramento genético. Assim, em Maio de 2003, um teste de procedências e progênies de $M$. scabrella foi instalado na Estação Experimental de Itatinga (ESALQ/USP), utilizando oito procedências nativas e uma comercial, coletadas ao longo da distribuição geográfica da espécie. O delineamento usado foi o Blocos de Famílias Compactas, com nove procedências, 10 a 20 progênies por procedência, seis plantas por subparcela e cinco repetições. Seis meses após o plantio foi medido o caráter altura total e sobrevivência de plantas no ensaio. Concomitantemente, uma amostra de aproximadamente 50 plantas por procedência foi usada para a analise de eletroforese de isoenzimas, revelando-se sete locos polimórficos. Os resultados mostraram que a espécie tem sistema misto de reprodução com predomínio de cruzamentos (média de $\hat{t}_{m}=0,971$ ). 
Na média das procedências foi detectada 7,6\% de cruzamento entre indivíduos parentes e 51,3\% de cruzamentos biparentais, indicando fortes desvios de cruzamentos aleatórios e que as progênies são constituídas por misturas de diferentes tipos de parentescos. Em concordância, o coeficiente médio de parentesco entre plantas dentro de progênies foi alto $(0,392)$. A análise da diversidade genética detectou altos níveis de heterozigosidades $\left(\hat{H}_{e}=0,580 ; \hat{H}_{o}=0,530\right)$, embora em duas procedências (CaçadorSC e Ituporanga comercial-PR) foram detectados excessos significativos de homozigotos em relação ao esperado sob Equilíbrio de Hardy-Weinberg. O estudo da associação entre distância genética de Nei (1978) com a distância geográfica entre procedências, usando o teste de Mantel, não detectou correlação significativa ( $\hat{r}=0,198 ; \hat{P}=0,159)$, de forma que não é possível atribuir o padrão de distância genética observado entre procedências ao modelo isolamento por distância. A comparação da medida de divergência genética entre procedências detectada por caracteres quantitativos $\left(\hat{Q}_{p}=0,039\right)$ com a detectada por locos isoenzimáticos $\left(\hat{\theta}_{p}=\right.$ 0,018) sugere que a divergência genética quantitativa observada entre as procedências aos seis meses de idade para o caráter altura foi causada por seleção divergente $\left(\hat{Q}_{p}>\hat{\theta}_{p}\right)$. Parâmetros genéticos foram estimados para o caráter altura, usando os modelos aleatório (assume progênies de polinização livre como meios-irmãos) e misto de reprodução (assume progênies de polinização livre como misturas de diferentes parentescos). A estimativas da variância genética aditiva, os coeficientes de herdabilidade e os ganhos esperados na seleção foram superestimados em 36\%, $48 \%$ e $41 \%$, respectivamente, quando o modelo aleatório de reprodução foi usado ao invés do modelo misto de reprodução.

Palavras-chave: Mimosa scabrella; teste de procedências e progênies; sistema de reprodução; estrutura genética; melhoramento genético. 


\title{
GENETIC STRUCTURE IN BRACATINGA POPULATIONS (Mimosa scabrella Benth.) FOR QUANTITATIVE TRAIDS AND ISOZYME MARKERS
}

\author{
Author: GRACIELA DA ROCHA SOBIERAJSKI \\ Adviser: PROF. DR. PAULO YOSHIO KAGEYAMA
}

\section{SUMMARY}

Mimosa scabrella Bentham (Bracatinga), is a native tree species of Atlantic Forest, of restricted occurrence to the Southwest and South of Brazil (RS, SC, PR and SP). The species comes being cultivated in the Brazil south and in the other countries as Costa Rica and Ruanda, for the most varied ends. But, although the species has a varied ends, lack studies in the genetic breeding. Thus, in May of 2003, a M. scabrella provenance progeny test was implanted in the Experimental Station of Itatinga (ESALQ/USP). The design used was the Compact Family Block with eight provenances, 10 to 20 families per provenance, six plants per subplot and five replications (block). Total height and survival at six months old were measured in the trials. Concomitantly, a sampled of about 50 plants per provenance was used to analyses of isozymes electrophoresis, reveling seven polymorphic loci. The results showed that the species has a mixed mating system with outcrossing predominance (average $\hat{t}_{m}=0.971$ ). In the provenance average was detected $7.6 \%$ of biparental inbreeding and $51.3 \%$ of biparental outcrossing, indicating strong deviations of random mating and that the families are mixtures of different relatedness kinds. In agreement, the average relatedness coefficient among plant within families was high (0.392). The analyses of genetic diversity detected high levels of observed and expected heterozygosities $\left(\hat{H}_{e}=0.580 ; \hat{H}_{o}=0.530\right.$, respectively), although in two provenances (Caçador-SC and Ituporanga comercial-PR) 
were detected significant excess of homozygotes in relationship to expected in HardyWeinberg equilibrium. The studied of association among Nei (1978) genetic distance and geographic distances among provenances, using Mantel test, no detected significant correlation $(\hat{r}=0.198 ; \hat{P}=0.159)$, indicating that the observed genetic distance among provenance patters is not possible to attribute the isolation distance model. The comparison of genetic divergence among provenance measured by quantitative traits $\left(\hat{Q}_{p}=0.039\right)$ with the measure by isozymes loci $\left(\hat{\theta}_{p}=0.018\right)$ suggest that the quantitative genetic divergence among provenance at six months old to height trait was caused by divergent selection $\left(\hat{Q}_{p}>\hat{\theta}_{p}\right)$. Genetic parameters were estimated to height trait, using the random (assume open-pollinated arrays with half-sibs) and mixed (assume open-pollinated arrays with mixed of different relatedness kinds) mating model. The additive genetic variance, heritabilities coefficients and expected gain selection were $36 \%, 48 \%$ and $41 \%$, respectively, super-estimates, where a random model was used instead of mixed mating model.

Key words: Mimosa scabrella; test of origins and lineages; reproduction system; genetic structure; genetic improvement. 


\section{INTRODUÇÃO}

Desde o início da colonização do Brasil, nossas florestas vêm sofrendo uma crescente exploração. O bioma mais afetado nesse período foi a Mata Atlântica, restando hoje cerca de 7\% de sua cobertura original. A Floresta Ombrófila Mista ou Mata de Araucária, é uma das formações inseridas nos domínios da Mata Atlântica, e tem ocorrência restrita ao sul do país. Dentro do bioma é a formação que apresenta maior fragmentação, restando apenas 5\% de sua área (MMA, 2002). Nas últimas décadas iniciaram-se trabalhos com o objetivo de preservar esses poucos remanescentes de Mata Atlântica, e também de restaurar ambientes degradados pelo desmatamento, uso intensivo da agropecuária e minerações. A caracterização dessas formações florestais (estudos fitossociológicos, de distribuição espacial das espécies, processos ecológicos e genéticos) é imprescindível para orientar os programas de uso e conservação.

Com o desenvolvimento de técnicas de análises moleculares (isoenzimas, RFLP, microssatélites), muitos trabalhos têm caracterizado a variabilidade genética das espécies arbóreas nativas, dos diferentes grupos sucessionais. Estudos têm mostrado que a variação genética isoenzimática difere entre espécies e grupos taxonômicos e que a variação dentro das populações está associada às características dos históricos de vida das espécies, como por exemplo, a distribuição geográfica, o sistema de reprodução, o tempo de fecundidade e os mecanismos de dispersão de pólen e sementes (Brown, 1978; Hamrick, 1983; Hamrick \& Godt, 1990). Também tem sido verificado que a variabilidade isoenzimática para espécies arbóreas tropicais é maior que para a média das espécies arbóreas e plantas anuais (Hamrick, 1983). 
A Mimosa scabrella Benth., ou bracatinga, é uma espécie arbórea leguminosa nativa de grande importância socio-econômica no sul do Brasil. Essa árvore vem sendo cultivada nos arredores de Curitiba - PR desde o início do século XX, consistindo no sistema agroflorestal mais antigo do país. O cultivo é praticado por pequenos e médios proprietários, geralmente pouco capitalizados, e principalmente em terrenos declivosos (Carpanezzi, 1997). Na região, é utilizado o sistema tradicional (Carpanezzi, 1997), onde nos primeiros anos, a floresta é implantada juntamente com culturas agrícolas (milho, mandioca, feijão...) (Carpanezzi, 1994).

Apesar do amplo uso, pouco se tem estudado em relação à estrutura genética e ao melhoramento da espécie. Em situações onde a espécie possui uso regular pelos produtores e não apresenta problemas em plantios de alta densidade, o melhor plano para conservação da mesma é a instalação de bancos de conservação ex situ, principalmente sob a forma de testes de procedências e/ou progênies. Essa estratégia permite aos pesquisadores realizarem estudos de genética populacional e de melhoramento genético, ao mesmo tempo em que a amostra de indivíduos permanece conservada.

Diante do exposto, esse trabalho buscou estudar a estrutura genética em oito populações naturais e uma comercial de $M$. scabrella, localizadas ao longo da distribuição natural da espécie. Para o efetivo conhecimento da estrutura genética da espécie investigaram-se o sistema de reprodução e os níveis de variabilidade via marcadores isoenzimáticos e caracteres quantitativos. Deseja-se com esse estudo contribuir para as medidas de conservação e auxiliar em futuros programas de melhoramento genético da espécie $M$. scabrella.

Especificamente buscou-se:

- Estudar o sistema de reprodução de nove populações de M. scabrella;

- Determinar a variabilidade genética entre e dentro das populações de M. scabrella, via caracteres quantitativos e marcadores isoenzimáticos;

- Comparar a divergência genética, obtida por marcador isoenzimático e caracteres quantitativos, entre as populações ao longo da distribuição geográfica da espécie; 
- Estudar a influência do sistema de reprodução misto nas estimativas dos parâmetros utilizados no melhoramento da espécie. 


\section{REVISÃO DE LITERATURA}

\subsection{A espécie Mimosa scabrella Benthan}

A Mimosa scabrella Bentham, popularmente conhecida como bracatinga, é uma espécie leguminosa de ocorrência restrita aos estados do Rio Grande do Sul, de Santa Catarina, do Paraná e de São Paulo. São reconhecidas e cultivadas duas variedades botânicas de M. scabrella: a variedade scabrella (conhecida como típica), e a variedade aspericarpa (Hoehne) Burkart (conhecida como argentina). Apesar do nome popular, ambas tem ocorrência restrita ao Brasil (Carpanezzi, 1994).

Nativa de climas frios, a $M$. scabrella tem ocorrência restrita na Floresta Ombrófila Mista, entre as latitudes $21^{\circ} 30^{\prime} \mathrm{S}$ e $29^{\circ} 40^{\prime} \mathrm{S}$, e longitudes $48^{\circ} 30^{\prime} \mathrm{W}$ e $53^{\circ}$ 50' W (Carvalho, 1994). A altitude pode variar de 500 a $1500 \mathrm{~m}$. O clima predominante é, segundo a classificação de Köeppen, o Cfb (Rotta \& Oliveira, 1981). Nessa zona de distribuição, ocorrem invernos rigorosos e apresenta umidade constante, sendo a espécie resistente a geadas (Iede, 1981).

Segundo Carvalho (1994), a M. scabrella é uma planta perenifólia, heliófita e indiferente às condições do solo. Trata-se de uma espécie comum em associações secundárias, onde pode formar agrupamentos densos e quase puros, e sendo pouco freqüente em matas bem conservadas (Carpanezzi, 1997). Em populações naturais, as árvores podem viver até 30 anos e atingir $20 \mathrm{~m}$ de altura e DAP de $40 \mathrm{~cm}$ (Carpanezzi, 1997).

A espécie apresenta tronco reto e esbelto quando plantada densamente, ou curto e ramificado em árvores isoladas (Carpanezzi, 1994). As suas folhas são compostas (paripinadas), e muito variáveis em número de pares de pinas (4-14 pares), e em número de folíolos por pinas (15-30 pares). 
Como na maioria das Mimosoideae, as flores são reunidas em inflorescências do tipo capítulo globoso (geralmente em número de três). As flores são muito pequenas, de corolas gamopétalas verdes, e com pistilo e estames livres amarelos (Catharino et al., 1982). Os pistilos geralmente alcançam a maturação antes da liberação do pólen, em uma mesma flor (Catharino et al., 1982). O fruto é do tipo Legume Craspédio, o qual caracterizasse pela fragmentação transversal do pericarpo, mas essa não atinge as bordas que ficam inteiras e persistem (Barroso et al., 1999). O legume apresenta cor marrom clara com, em média, quatro sementes. Suas sementes apresentam dormência tegumentar sendo impermeáveis à água (Carpanezzi, 1997).

A indução à germinação pode ser realizada de duas formas: no campo e em laboratório (ou viveiro). O modo realizado tradicionalmente é a queima dos resíduos da rotação anterior no campo. Mas essa prática vem sendo desvalorizada ao mesmo tempo que crescem as preocupações com a perda de nutrientes, conservação do solo e a poluição ambiental. A alternativa é a produção de mudas em viveiros, deixando as sementes imersas em água a $80{ }^{\circ} \mathrm{C}$ (fora do aquecimento) por 5 minutos, ou em ácido sulfúrico puro, variando de 1 a 4 minutos (Fonseca, 1982). Apesar de recomendada, esta prática é pouco utilizada visto que os custos de implantação aumentam consideravelmente (Graça \& Mendes, 1987). Outra forma seria a escarificação mecânica, que desprende muito tempo, porém apresenta boa germinação.

O florescimento inicia-se a partir dos oito meses sendo pouco abundante, normalizando aos três anos. A floração inicia-se em abril prolongando até setembro (var. scabrella), enquanto que a variedade aspericarpa floresce em novembro e dezembro. A intensidade de floração altera anualmente em conseqüência da variação climática. $O$ auge da floração ocorre no inverno, o que justifica a importância dessa espécie para apicultura (Carpanezzi, 1994). A frutificação estende-se pelos meses de dezembro até março (Cardoso, 1979).

As flores da $M$. scabrella não necessitaram de especializações por parte dos polinizadores, mostrando-se uma espécie autofílica (Catharino et al., 1982). Alguns possíveis polinizadores já foram reconhecidos, como por exemplo, Apis mellifera, Melipona marginata, M. quadrifasciata e Plebeia remota (Pirani, 1994). Catharino et al. 
(1982) observaram além da A. mellifera, a Trigona sp. visitando as flores da $M$. scabrella.

A exploração da madeira ocorre aos oito anos, quando a produção volumétrica atinge entre 12 e $15 \mathrm{~m}^{3} /$ ha (Carvalho, 1994), sob regeneração natural. A segunda rotação é normalmente induzida pelo fogo, que favorece a quebra da dormência tegumentar de suas sementes (Carpanezzi, 1994). Assim, o reflorestamento com a bracatinga torna-se muito fácil e pouco dispendioso para os pequenos produtores (Carvalho, 1981b). Ao contrário de outras pioneiras utilizadas em reflorestamentos, a $M$. scabrella não rebrota após o corte ou fogo, facilitando o controle de invasões indesejadas (Carpanezzi et al., 1990).

Atualmente, o seu principal produto de exploração é madeira para lenha e carvão, sendo a produção de mel um subproduto pouco extraído pelos apicultores. Sua madeira proporciona lenha e carvão de excelente qualidade devido a sua alta densidade $(0,58$ $\mathrm{g} / \mathrm{m}^{3}$ ) (Carpanezzi, 1997). O carvão proveniente dessa árvore tem alto rendimento, com elevado teor de carbono fixo (Lisbão Júnior, 1981), e poder calorífico entre 7.239 e $7.554 \mathrm{Kcal} / \mathrm{kg}$ (Carvalho, 1994). Porém, apresenta o inconveniente de possuir alto teor de cinzas (Lisbão Júnior, 1981; Pereira \& Lavoranti, 1986).

Por essa ser a principal utilização da $M$. scabrella, vários trabalhos foram realizados, como os de Pereira \& Lavoranti (1986) e Shimizu (1987) que estudaram três procedências de M. scabrella: Caçador (SC), Concórdia (PR) e Colombo (PR), visando comparar a qualidade da madeira. Pereira \& Lavoranti (1986) não encontraram diferenças significativas entre as procedências para as características de densidade básica e teor de lignina. Entretanto, Shimizu (1987) considerou a procedência de Concórdia superior às demais para a característica de produtividade volumétrica, sendo $214 \%$ superior à testemunha comercial. Fonseca (1982) encontrou variações relacionadas com o gradiente latitudinal principalmente para características das sementes, embora não tenha sido encontrada variação significativa para densidade básica da madeira.

Segundo Carvalho (1981a) a espécie apresentou crescimento superior em relação a outras 19 nativas e duas exóticas, em quatro locais no Paraná. Com exceção do 
guapuruvu - Schizolobium parahyba (em apenas um local), a M. scabrella apresentou os melhores resultados para altura a taxa de sobrevivência.

A M. scabrella produz um mel escuro, mas de boa aceitação no mercado. Pegorado \& Carpanezzi (1995) estimaram em seu trabalho a produção de mel em $120 \mathrm{Kg}$ de mel/ha, o que pode ser considerada uma boa produção. Segundo análise desenvolvida por Cardoso (1979), o "mel de inverno" possui vitaminas A, B e C e uma quantidade maior de sais minerais, o que o torna muito nutritivo, além de apresentar essências perceptíveis ao olfato e ao paladar. A concentração média de açúcar encontrada nesse mel é de 24,16\% (Pegorado \& Carapanezzi, 1992).

Além dos usos com finalidades energéticas e melíferas, a $M$. scabrella também apresenta utilização como escoras para construção, madeira serrada, forrageira, sombreadora para outras culturas, extração de goma (trigalactosil pinitol e galactomanana), e para recuperação de solos degradados (Carvalho, 1994), entre outros.

No Paraná, Poggiani et al. (1982) utilizaram a espécie na recuperação de solos degradados pela exploração de xisto betuminoso. Nesse local, observou-se uma acentuada deposição de nitrogênio e fósforo pelas folhas da M. scabrella. A toxidade do alumínio e manganês presentes no solo pareceu não ter causado danos as plantas.

Picado (1985, citado por Carpanezzi, 1997), relatou que na Costa Rica, a $M$. scabrella é muito utilizada como sombreadora para o café. Com a mesma finalidade a espécie é utilizada na Guatemala desde 1940 (Carvalho, 1994). Enquanto que em locais de altitude em Ruanda, as suas folhas são utilizadas como forragem para caprinos (Nyang et al., 1994). Por fornecer vários produtos, a M. scabrella é considerada uma espécie de "uso múltiplo", sendo seu cultivo difundido no Brasil e em outros países (Carpanezzi, 1997).

\subsection{Sistema de reprodução}

O sistema de reprodução é o modo como as espécies transferem suas informações genéticas de uma geração para outra (Wright, 1921). Existem três tipos de sistemas de reprodução: a autogamia, a alogamia, e o misto. Na autogamia ocorre a fusão dos gametas masculino e feminino de um mesmo indivíduo para a formação de um 
novo, por meio da autopolinização. Sucessivos ciclos de autofecundação, ineviatavelmente, geram a homozigose (Ramalho et al., 2001), e por consequiência, uma menor diversidade genética.

A reprodução das espécies alógamas ocorre através do acasalamento entre plantas, assim, um indivíduo qualquer é oriundo de gametas femininos e masculinos de plantas diferentes (Souza Júnior, 2001). Dessa forma, as plantas podem apresentar seus locos em homozigose ou heterozigose. Esse último permite que alelos recessivos, ou deletérios, permaneçam ocultos nas populações, ocasionando uma redução de vigor quando as espécies alógamas são submetidas à endogamia (Allard, 1971).

O terceiro tipo, o sistema misto de reprodução, é uma mistura dos dois processos anteriores, em maior ou menor intensidade de cada um. Normalmente, diz-se que uma espécie é de reprodução mista com predominância à alogamia, ou à autogamia, conforme a relação entre as taxas de cruzamento e autofecundação.

Nas últimas décadas a aplicação de estudos do comportamento floral, utilizando técnicas moleculares e a elaboração de modelos estatísticos mais complexos têm permitido descrever, de forma mais detalhada, os sistemas de reprodução de várias espécies (Clegg, 1980). Dois trabalhos são clássicos nessa área: Bawa (1974) e Hamrick (1983). Um dos primeiros estudos do sistema de reprodução em espécies arbóreas tropicais, realizado por Bawa (1974), através de polinização controlada e observações sobre a biologia floral das espécies comprovou que 79,4\% das espécies possuíam algum mecanismo de auto-incompatibilidade, inclusive as que possuem flores hermafroditas. A predominância pela fecundação cruzada nas espécies das florestas tropicais reflete a importância dos agentes polinizadores nesse ambiente.

A evolução das técnicas moleculares e dos modelos estatísticos possibilitou a estimativa das taxas de cruzamento e de autofecundação das espécies de reprodução mista. Tais estudos têm demonstrado que as espécies florestais tropicais, na sua maioria, apresentam sistema misto de reprodução com predominância à alogamia (Hamrick, 1983). Sebbenn (2001) reunindo vários trabalhos pode concluir que as espécies arbóreas tropicais possuem, em média, taxa de cruzamento de 0,880, sendo a média para as espécies arbóreas de 0,851. Outra compilação de trabalhos, realizado por Kageyama et 
al. (2001), detecta que a taxa de cruzamento das espécies oscila entre 0,82 e 0,98, variando conforme a espécie e quanto ao grupo sucessional ao qual pertence.

Por haver espécies que variam desde a total autogamia até a alogamia, percorrendo por diferentes níveis de combinação entre os dois sistemas, a elucidação do sistema de reprodução tem grande importância nos programas de conservação e melhoramento, visto que é esse hábito que irá determinar a estrutura genética que terão as suas populações.

\subsection{Diversidade genética}

A biodiversidade é um termo que adquiriu grande importância nos últimos anos. De uma forma geral, representa a somatória de todas formas de vida existentes, incluindo os vários habitats e a diversidade genética dessas (Valois et al., 1996). A biodiversidade, ou simplesmente diversidade, pode ser quantificada conforme sua distribuição entre e/ou dentro de biomas, de ecossistemas, e de populações. É fundamental para a conservação e o manejo dos recursos genéticos entender as causas, a manutenção e como a diversidade se distribui desde grandes biomas até ao nível de genes. Dentre os níveis classificados, a diversidade genética entre e dentro de populações de uma espécie merece consideração especial pois, os efeitos das alterações nas freqüências alélicas são refletidos diretamente sobre os indivíduos que formam a população.

Os estudos de genética de populações avançaram significantemente na década de 60, a partir do desenvolvimento de técnicas de marcadores moleculares. Há uma grande amplitude de ferramentas passíveis de serem utilizadas em trabalhos de caracterização da diversidade genética, como os marcadores fenotípicos (altura, cor de pétalas), e moleculares (isoenzimas, RAPD, RFLP, microssatélites) (Ferreira \& Grattapaglia, 1998). Grande parte desses permite ao pesquisador caracterizar de forma rápida e fácil a variabilidade genética das populações de interesse.

A diversidade genética permite que as populações possuam plasticidade para se adaptarem às modificações impostas pelo ambiente. Essa variabilidade é resultante da interação de diversos fatores evolutivos, dentre eles, a seleção natural, a deriva genética, 
a mutação e a migração. A seleção natural, assim como a deriva genética, diferencia as populações. A mutação cria diversidade ao passo que, normalmente, as alterações do genoma decorridas dessa não resultam da recombinação recíproca (Futuyma, 1992). E a migração (ou fluxo gênico) amplifica a diversidade por permitir a recombinação entre indivíduos de diferentes populações (Hartl \& Clark, 1997).

Estudos que quantifiquem e caracterizem a distribuição da diversidade genética de populações naturais são imprencidíveis para os planos de conservação, melhoramento e domesticação das espécies (Kageyama, 1987). Nos últimos anos, vários trabalhos têm estudado a variabilidade genética das espécies florestais nativas. Esses trabalhos têm mostrado que os valores obtidos para os diferentes parâmetros variam muito entre as espécies. Isso justifica a intensificação das pesquisas nessa área, refletindo a necessidade de gerar conhecimentos que possam ser utilizados para conservação dos remanescentes florestais.

\subsection{Variações genéticas por caracteres quantitativos e marcadores moleculares}

A variabilidade genética pode ser quantificada através de vários métodos que possibilitam a obtenção de diferentes parâmetros para realizar a sua caracterização. Durante muito tempo os marcadores fenotípicos foram utilizados para caracterização da variabilidade genética entre e dentro de populações, por esses apresentarem fácil detecção e mensuração. Esses marcadores podem ser utilizados porque os indivíduos diferem fenotipicamente entre si, mesmo quando comparados dentro de progênies (Hartl \& Clark, 1997).

O desenvolvimento de técnicas moleculares teve uma grande contribuição para os estudos de genética de populações e melhoramento genético por tornar possível a análise de cada população, ou indivíduo, de interesse em um pequeno espaço de tempo. Podemos utilizar qualquer forma alélica (fragmento de DNA ou a expressão de uma proteína codificada por ele), originada de um genoma como marcador genético (Souza, 2001).

Um ponto fundamental difere esses dois métodos de detecção da diversidade genética: a origem das diferenças encontradas por eles. A influencia ambiental sofrida 
pelos marcadores morfológicos é causada pela atuação da seleção natural em conjunto com a deriva genética. Diferentemente, as técnicas moleculares não apresentam a influência da seleção natural por seus locos serem, em geral, seletivamente neutros (Torggler et al., 1995). A deriva genética pode ser definida como uma mudança aleatória na freqüência gênica, e essa alteração contribui de forma significante para a diferenciação entre as populações, eventualmente fixando (e extinguindo) um dos alelos (Futuyma, 1992). As principais conseqüências da deriva genética são a perda da variabilidade genética dentro das populações e a divergência entre elas (Futuyma, 1992).

O conceito de seleção natural é o princípio fundamental na biologia evolutiva. Ele pode ser entendido como uma diferença não aleatória no desempenho dos indivíduos, e atua de maneira discriminativa sobre o seu fenótipo (Valois et al., 1996). As variações ocasionadas na frequiência alélica pela seleção natural são determinadas pelas circunstâncias presentes, não podendo moldar-se previamente à ambientes futuros (Futuyma, 1992). É fundamental reforçar que a deriva genética ocorre devido a fatores casuais, enquanto que na seleção natural há uma pressão seletiva exercida por um conjunto de fatores bióticos e abióticos sobre o indivíduo (Valois et al., 1996). A importância da seleção natural para o desenvolvimento dos caracteres adaptativos é inegável. Porém, os processos casuais são fundamentais no processo evolutivo dos organismos já que toda influência sobre o valor adaptativo depende da constituição prévia desses (Coelho \& Valva, 2001). Assim, a divergência encontrada entre as populações é resultante, principalmente, da interação em maior ou menos grau desses dois fatores evolutivos.

Um dos parâmetros utilizados para quantificar a variabilidade genética é divergência existente entre e dentro das populações. A divergência genética pode ser avaliada tanto por caracteres quantitativos quanto por marcadores isoenzimáticos. A união dessas duas técnicas pode promover valorosas discussões sobre qual a relação entre a deriva genética e a seleção natural como determinantes do processo evolutivo das populações (Torggler et al., 1995). 
A reunião das duas técnicas possibilita fazer inferências sobre o efeito da seleção natural na divergência entre as populações. Comparando os resultados de divergência genética entre populações estimadas por marcadores isoenzimáticos $\left(\theta_{\mathrm{ST}}\right)$ com o obtido para os caracteres quantitativos $\left(\mathrm{Q}_{\mathrm{ST}}\right)$ pode-se fazer inferências sobre a origem dessa divergência (Sebbenn et al., 2001a). Segundo a hipótese de divergência seletiva (Wright, 1951; Lande, 1992), não podemos negar que a seleção divergente esteja atuando caso os valores encontrados para $\mathrm{Q}_{\mathrm{ST}}$ sejam significativamente maiores que os obtidos para $\theta_{\mathrm{ST}}$. Porém, se $\mathrm{Q}_{\mathrm{ST}}$ apresentar valores semelhantes ou significativamente menores que $\theta_{\mathrm{ST}}$, não podemos recusar a hipótese de que essa divergência esteja sendo causada principalmente pela deriva genética (Yang et al., 1996).

Apesar da relevância do assunto, poucos estudos realizando a comparação dos dados obtidos por caracteres quantitativos e marcadores isoenzimático foram realizados (Hamrick, 1983). Moraes (1982) ao utilizar as isoenzimas e os caracteres quantitativos para estudar a estrutura genética de duas populações de Myracrodruon urundeuva observou alta coerência entre os resultados, mostrando que em ambos os casos a maior parte da variabilidade genética encontrava-se dentro de progênies. Com o objetivo de investigar as causas da divergência observada entre as populações de Pinus contorta ssp. latifolia Yang et al. (1996) estudaram cinco populações utilizando informações obtidas de 19 sistemas isoenzimáticos e seis caracteres quantitativos. Em dois caracteres a hipótese de divergência seletiva não pode ser aceita, mostrando que há diferentes pressões seletivas entre os caracteres quantitativos (Yang et al., 1996). Jaramillo-Correa et al. (2001) encontraram resultados semelhantes ao estudar a espécie Picea glauca. Para quatro caracteres quantitativos estudados (de um total de 10), o valor encontrado de divergência entre populações foi maior do que o encontrado para isoenzimas (JaramilloCorrea et al., 2001). Sebbenn et al. (2001a) não encontraram divergências significativas entre as populações estudadas de Cariniana legalis. Por se tratar de uma espécie longeva pode ser que não tenha transcorrido tempo suficiente para que as divergências tenham se acentuado, seja por efeito da deriva genética, ou por seleção natural (Sebbenn et al., 2001a). González-Martínez et al. (2002) comparando as divergências encontradas entre 19 populações por caracteres quantitativos e isoenzimas, concluíram que, para a espécie 
Pinus pinaster, todos valores encontrados para os três caracteres quantitativos estudados foram maiores que o observado para a média dos locos de isoenzimas.

De uma forma geral, os resultados encontrados por diversos autores para espécies arbóreas mostram haver forte congruência entre os dados obtidos por caracteres quantitativos e marcadores isoenzimáticos. Assim, torna-se essenciais os trabalhos que combinem técnicas de marcadores moleculares aos de genética quantitativa visando um melhor entendimento de como os processos evolutivos estão atuando sobre as populações, e como isso afeta a conservação e o melhoramento dos recursos genéticos ali existentes. 


\section{ESTUDO PRELIMINAR DO SISTEMA DE REPRODUÇÃO EM NOVE PROCEDÊNCIAS DE Mimosa scabrella BENTHAN (LEGUMINOSACEAE) - PRELIMINAR STUDIED OF MATING SYSTEM IN NINE Mimosa scabrella BENTHAN PROVENANCES (LEGUMINOSACEAE)}

\section{Resumo}

O sistema de reprodução de nove procedências de Mimosa scabrella da floresta subtropical do Brasil foi investigado por análise de isoenzimas usando o modelo misto de reprodução e o modelo de cruzamentos correlacionados. Em geral, o índice de fixação estimados nas árvores maternas ( $\hat{F}$, variando de zero a 0,040$)$ foi menor do que o obtido nas progênies ( $\hat{F}_{p}$, variando de $-0,022$ a 0,154$)$ sugerindo seleção contra homozigotos durante o crescimento das plântulas até a fase reprodutiva. Desvios do modelo misto de reprodução ficaram evidentes nas diferenças entre as freqüências alélicas dos óvulos e do pólen. A espécie foi encontrada por ser predominantemente de cruzamento $\left(\hat{t}_{m}\right.$ entre procedências variando de 0,859 a 1,000). As diferenças entre a taxa unilocus e multilocus foram positivas e significativas $\left(\hat{t}_{m}-\hat{t}_{s}\right.$, variando entre procedências de 0,012 a 0,105) indicando endogamia biparental e provável estrutura genética espacial nas procedências. A correlação de autofecundação foi baixa, mas significativa nas procedências $\left(\hat{r}_{s}\right.$, variando de 0,013 a 0,310), sugerindo possível variação na auto-incompatibilidade entre árvores. A correlação de paternidade observada entre procedências foi alta e significativa ( $\hat{r}_{P}$, variando de 0,153 a 0,694 ), indicando alta proporção de irmãos-completos dentro das progênies. 
As estimativas do coeficiente de coancestria dentro de progênies ( $\hat{\theta}_{x y}$ variando de 0,145 a 0,220$)$ foram maiores do que as esperadas em progênies de meios-irmãos $(0,125)$. A estimativa do tamanho efetivo de variância médio das progênies ( $\hat{N}_{e(v)}$ variando de 2,27 a 3,46) foi menor do que o esperado em uma procedência idealizada $\left(\hat{N}_{e(v)}=4\right)$ indicando fortes desvios de cruzamentos aleatórios. Os resultados são discutidos na ótica do melhoramento e conservação genética.

Palavras-chave: Mimosa scabrella, isoenzimas, endogamia, coancestria, sistema misto de reprodução. 


\section{Summary}

The mating system in nine Mimosa scabrella populations form Brazil subtropical forest was investigated by allozyme analysis using the multi-locus mixed-mating system and correlated mating models. In general, the fixation index estimates in mother trees ( $\hat{F}$, range zero to 0.040$)$ was lower than that obtained for progeny arrays $\left(\hat{F}_{p}\right.$, range to 0.022 to 0.154 ) suggesting selection against selfed progenies during grown of seedlings to reproductive size. Departures from the mixed-mating model were evident from differences in pollen and ovule allele frequencies. The species was found to be predominantly outcrossed ( $\hat{t}_{m}$ among populations ranged 0.859 to 1.000$)$. Differences between multi-locus and single-locus were positives and significant $\left(\hat{t}_{m}-\hat{t}_{s}\right.$, range between population at 0.012 to 0.105 ) indicating biparental inbreeding and probably spatial genetic structure in the populations. Correlation of selfing was lower, but significant in the populations ( $\hat{r}_{s}$, range to 0.013 to 0.310 ), suggesting possible variation in auto-incompatibility among trees. High and significant estimates of correlation of paternity were observed among populations ( $\hat{r}_{P}$, range 0.153 to 0.694$)$, indicating high proportion of full-sibs within families. The estimates of coefficient of coancestry within families $\left(\hat{\theta}_{x y}\right.$ ranged 0.145 to 0.220$)$ were larger than that expected in half-sibs $(0.125)$.

The variance effective population size estimates were lower $\left(\hat{N}_{e(v)}\right.$ range 2.27 to 3.46 ) than the expected in a idealized population $\left(\hat{N}_{e(v)}=4\right)$ indicating strong deviations of random matins. The results are discussed in the sense of genetic improvement and conservation.

Keywords: Mimosa scabrella, isozymes, inbreeding, coancestry, mixed mating system. 


\subsection{Introdução}

Mimosa scabrella Bentham (Leguminosae-Mimosoideae) ou bracatinga é uma espécie arbórea subtropical brasileira que ocorre naturalmente entre que as latitudes $21^{\circ} 30^{\prime}$ S (Coronel Pacheco-MG) a 29² 's (RS), abrangendo os Estados de Minas Gerais (sul), Rio de Janeiro, São Paulo (leste e sul), Paraná (sul e centro sul), Santa Catarina e Rio Grande do Sul (nordeste) em altitudes preferencialmente entre $400 \mathrm{~m}$ a $1.000 \mathrm{~m}$ (Carvalho, 1994). Sua frequiência é descontínua, tornando-se as vezes muito abundante, especialmente nas florestas de araucária semi-devastadas e nas condições de vegetação secundária (Reitz et al., 1978). Suas flores são polinizadas principalmente por abelhas do tipo Apis e Trigona e tem suas sementes dispersas por autocoria. Seu crescimento é rápido até aproximadamente os seis anos de vida, após entra em fase de crescimento lento e posteriormente (10 a 12 anos) tendem a entrar em fase de declínio vital.

O sistema de reprodução em plantas é afetado por uma ampla extensão de fatores externos as plantas, tais como vetores e comportamento de polinização e, dentro de plantas, tais como fenologia floral e alocação de recursos dentro de frutos (Millar et al., 2000). Outro mecanismo interno, de origem genética, tal como a auto-incompatibilidade também afeta o sistema de reprodução de plantas. Esses fatores geram variações no sistema de reprodução entre frutos dentro de plantas, entre plantas dentro de populações

e entre populações. O conhecimento da variação no sistema de reprodução em populações de uma espécie é de fundamental importância para o delineamento de estratégias para a conservação e o melhoramento genético, visto que permite a aplicação de métodos amostrais mais efetivos e a aplicação de modelos matemáticos mais precisos no estudo da herança quantitativa de caracteres de interesse econômico.

Espécies arbóreas tropicais geralmente apresentam sistema misto de reprodução com predomínio de cruzamentos. Segundo, Sebbenn (2001) a taxa de cruzamento média em espécies arbóreas folhosas é de 0,880 , o que pode ser considerado uma taxa alta.

O objetivo deste capitulo foi estudar o sistema de reprodução de nove procedências de $M$. scabrella usando sete locos isoenzimáticos e o modelo misto de reprodução e modelo de cruzamentos correlacionados. 


\subsection{Material e Métodos}

\subsubsection{Coleta das amostras}

Esse trabalho foi desenvolvido com material genético proveniente de oito procedências naturais e uma comercial, ao longo da distribuição geográfica de $M$. scabrella. Para a escolha das localidades foram consideradas as seguintes observações: existência de procedências conhecidas e bem conservadas; e que as procedências apresentassem um número de matrizes suficiente (aproximadamente, 20 matrizes). Também foi observada a recomendação de Kemp (1976), respeitando uma distância máxima de 1 grau de latitude entre as procedências. Em cada município foi localizada uma procedência, exceto Ituporanga com uma procedência natural e uma comercial. A identificação das procedências e a coleta das sementes foram realizadas por técnicos da EMBRAPA/CNPF entre os anos de 1997 e 1999. A localização dos municípios está descrita na Tabela 1 e demonstrada na Figura 1.

Em cada local (procedência) foram coletadas sementes de 10 a 20 árvores matrizes. De cada árvore foram coletadas sementes suficientes para produção de 50 mudas por progênies. As sementes foram germinadas separadas por progênie no viveiro do Departamento de Ciências Florestais da ESALQ/USP. O teste de procedências e progênies foi instalado em Maio de 2003 na Estação Experimental de Itatinga ESALQ/USP, município de Itatinga-SP (latitudes $23^{\circ} 02^{\prime} 01^{\prime}$ ' S e $23^{\circ} 02^{\prime} 30^{\prime}$ ' S; longitudes $48^{\circ} 38^{\prime} 34^{\prime}$ ' W e $48^{\circ} 37^{\prime} 30^{\prime}$ ' W; altitude média de $830 \mathrm{~m}$; temperatura média anual de $19,4{ }^{\circ} \mathrm{C}$ e mínima de $12,8{ }^{\circ} \mathrm{C}$; precipitação média de $1.635 \mathrm{~mm}$ e nos mês mais secos (julho) de 30 a $60 \mathrm{~mm}$ ) (Scardua, 1994). O delineamento experimental usado foi o de "Blocos de Famílias Compactas" (Wright, 1978), com nove procedências representando o efeito de parcela, 10 a 20 progênies por procedência, representando o efeito de subparcela, seis plantas por subparcela, em cinco repetições. O espaçamento adotado foi o 3,0 x 1,5 m. O experimento foi rodeado por uma bordadura externa de três linhas.

Para caracterizar os níveis e a distribuição da diversidade genética entre e dentro das procedências a partir de dados de isoenzimas foram coletados tecidos foliares em 
parte do experimento. Com o intuito de avaliar os efeitos do crescimento das árvores nos níveis de diversidade genética isoenzimática e índice de fixação, foram coletadas amostras, em cada procedência, das 10 plantas com maior altura, das $10 \mathrm{com}$ menor altura, e de 30 plantas aleatórias no restante da procedência (entre as 10 menores e as 10 maiores). Aproximadamente 50 indivíduos foram amostrados por procedência, totalizando 450 plantas no total do ensaio. As folhas foram coletadas, embaladas em sacos plásticos devidamente identificados com o número da árvore de origem e transportadas para o Laboratório de Reprodução e Genética de Espécies Arbóreas (LARGEA/ESALQ/USP), e submetidas imediatamente às análises de eletroforese de isoenzimas.

Tabela 1. Número de progênies por procedência $(m)$, coordenadas geográficas(altitude Lat; e longitude - Lon), altitude média (Alt) e temperatura média (T) dos municípios onde foram localizadas as procedências

\begin{tabular}{lccccc}
\hline \multicolumn{1}{c}{$\begin{array}{c}\text { Município / } \\
\text { Estado }\end{array}$} & $\boldsymbol{m}$ & $\begin{array}{c}\text { Lat } \\
\text { (Sul) }\end{array}$ & $\begin{array}{c}\text { Lon } \\
(\text { Oeste })\end{array}$ & $\begin{array}{c}\text { Alt } \\
(\mathbf{m})\end{array}$ & $\begin{array}{c}\text { T } \\
\left({ }^{\circ} \mathbf{C}\right)\end{array}$ \\
\hline Itararé / SP & 20 & $24^{\circ} 10^{\prime}$ & $49^{\circ} 16^{\prime}$ & 1000 & 19,0 \\
Piraí do Sul / PR & 19 & $24^{\circ} 50^{\prime}$ & $49^{\circ} 56^{\prime}$ & 1250 & 18,0 \\
Mandirituba / PR & 20 & $25^{\circ} 48^{\prime}$ & $49^{\circ} 18^{\prime}$ & - & - \\
Lapa / PR & 20 & $25^{\circ} 48^{\prime}$ & $49^{\circ} 41^{\prime}$ & 908 & 20,0 \\
Honório Serpa / PR & 20 & $26^{\circ} 11^{\prime}$ & $52^{\circ} 26^{\prime}$ & - & - \\
Turvo / PR & 20 & $25^{\circ} 03^{\prime}$ & $51^{\circ} 33^{\prime}$ & 1200 & 17,0 \\
Caçador / SC & 20 & $27^{\circ} 45^{\prime}$ & $51^{\circ} 00^{\prime}$ & 1000 & 16,2 \\
Ituporanga / SC & 10 (n) e 19 (c) & $27^{\circ} 24^{\prime}$ & $49^{\circ} 36^{\prime}$ & 360 & 17,3 \\
\hline
\end{tabular}

$(\mathrm{n})=$ procedência nativa; $(\mathrm{c})=$ procedência comercial. 


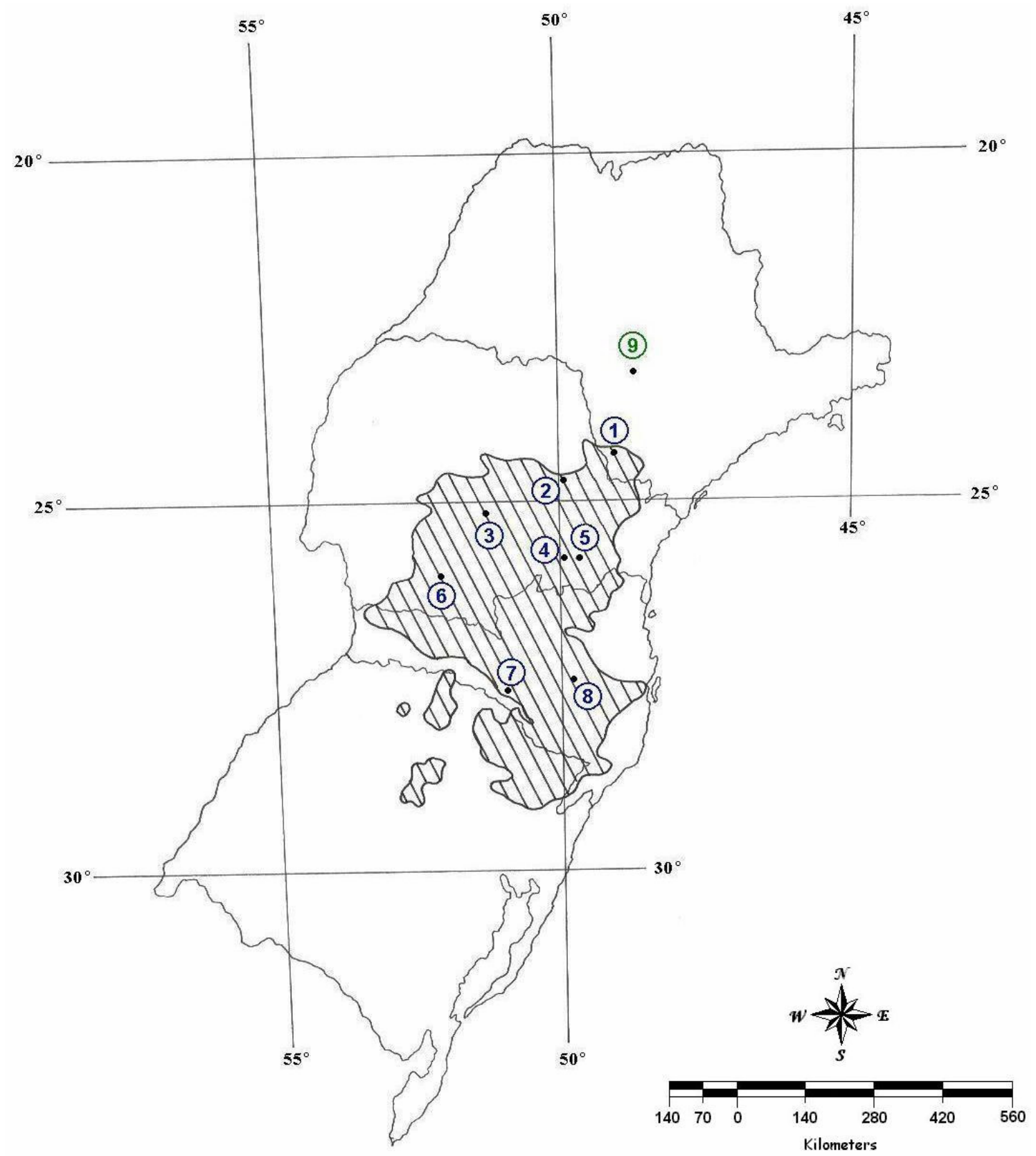

Figura 1- Mapa com a distribuição geográfica da espécie $M$. scabrella, e localização das prodecências e área de estudo (distribuição geográfica baseada em Rotta \& Oliveira, 1981) (1. Itararé - SP; 2. Piraí do Sul - PR; 3. Turvo - PR; 4. Lapa PR; 5. Mandirituba - PR; 6. Honório Serpa - PR; 7. Caçador - SC; 8. Ituporanga - SC; 9. Estação Experimental de Itatinga ESALQ/USP) 


\subsubsection{Eletroforese de iosenzimas}

O protocolo de extração e revelação das isoenzimas foi desenvolvido com base em Alfenas (1998). Para a extração das isoenzimas de tecidos foliares utilizou-se o tampão de extração número um, citado em Alfenas (1998, pág. 96). Para definição dos sistemas isoenzimáticos, foram testados três sistemas de tampão gel-eletrodo (Citrato Morfolina, Lítio Borato, e Tris Citrato), e 17 sistemas isoenzimáticos. As enzimas que apresentaram melhor atividade de resolução e permitiram a interpretação foram: Fosfogluco Isomerase (PGI-EC 5.3.1.9), Glucose-6-Fosfato Desidrogenase (G6PDHHEC 1.1.1.49), Leucina Aminopeptidase (LAP-EC 3.4.11.1), Malato Desedrogenase (MDH-EC 1.1.1.37), Isocitrato Desidrogenase (IDH-EC 1.1.1.42), Menadiona Redutase (MR-EC 1.6.99.2), e a 6-Fosfogluconato Desidrogenase (6PGDH-EC 1.1.1.44). As reações isoenzimáticas foram baseadas em Alfenas (1998). Porém, com a finalidade de melhorar a resolução da enzima Fosfogluco Isomerase (PGI), optou-se pela alteração na quantidade da enzima Glucose-6-Fosfato Desidrogenase de 6,5 $\mu \mathrm{l}$ para 7,5 $\mu \mathrm{l}$. Os padrões de revelação dos sistemas isoenzimáticos, assim como, as representações esquemáticas dos fenótipos observados nos zimogramas podem ser observadas nas Figuras 2 e 3.

\subsubsection{Amostragem}

O estudo do sistema de reprodução de $M$. scabrella foi realizado com material amostrado em um teste de procedências e progênies instalado na Estação Experimental de Itatinga (ESALQ/USP), em Maio de 2003. O teste abrangia nove procedências e 10 a 20 progênies por procedências, sendo oito procedências naturais e uma comercial. Para o estudo do sistema de reprodução foram amostradas entre sete e 12 progênies por procedências. O número de progênies amostradas variou de três a oito plantas. Ressaltase que o número de progênies e plantas por progênies usado na amostragem encontra-se longe do ideal, que seria de pelo menos 200 plantas por procedência. 


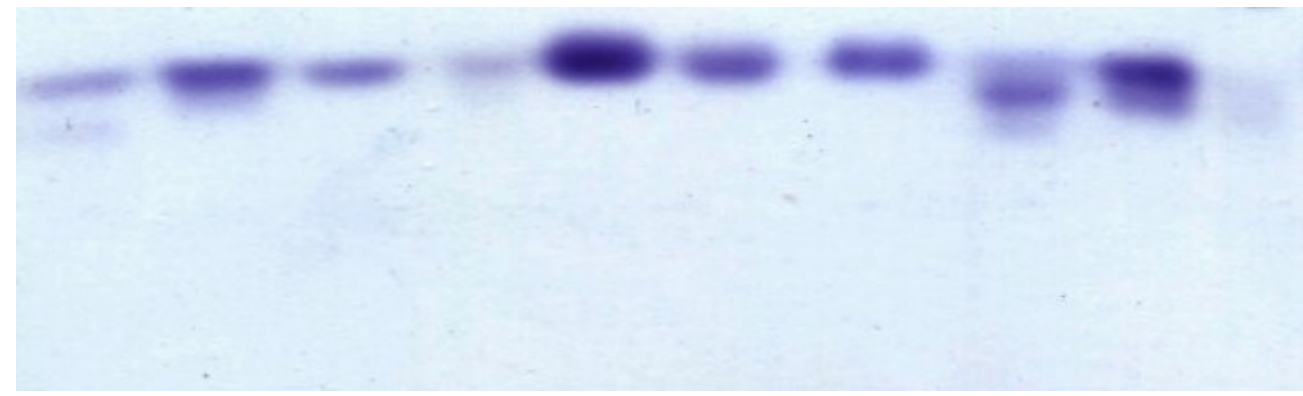

IDH

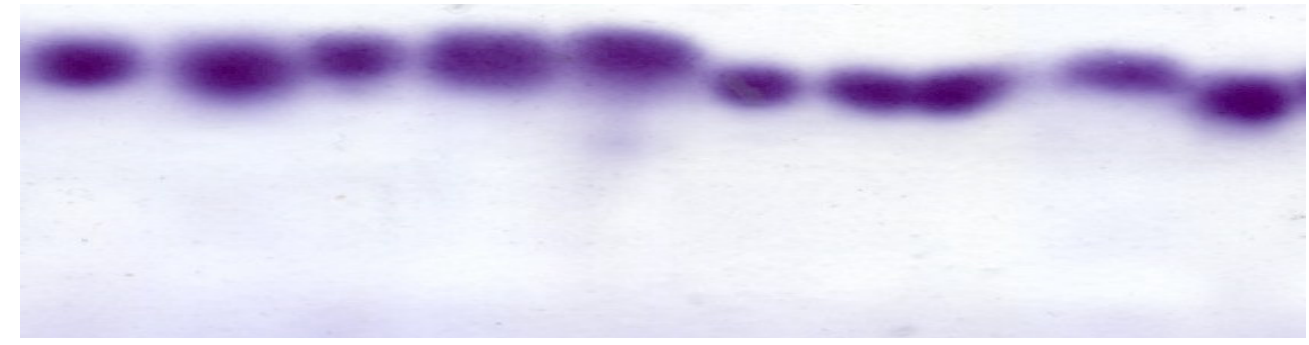

G6PDH

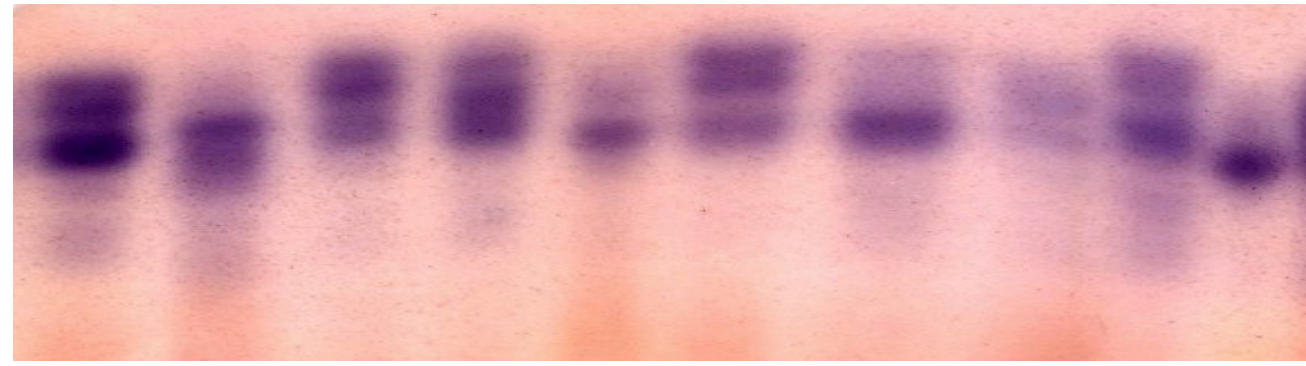

LAP

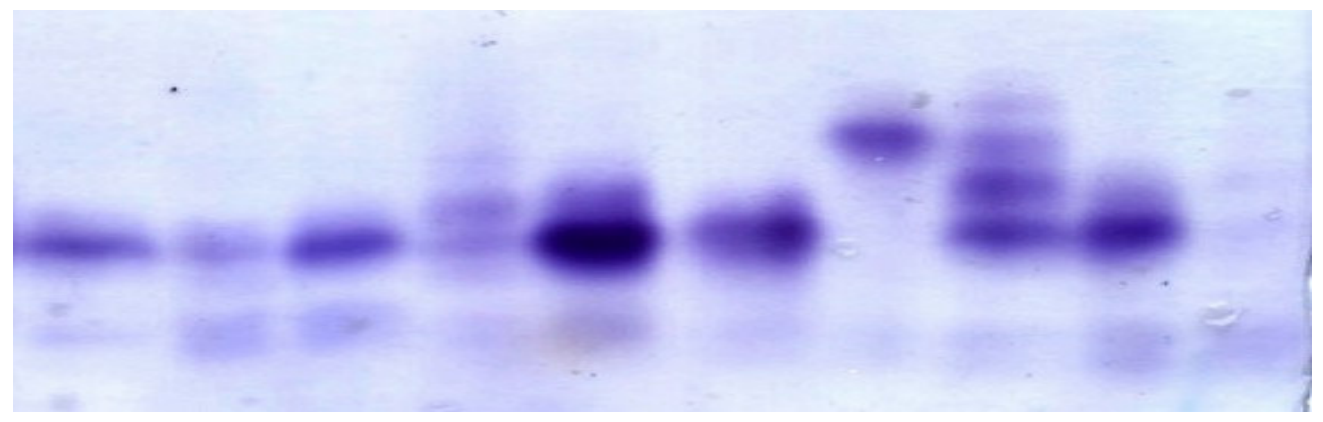

MR

Figura 2- Padrão de revelação dos sistemas isoenzimáticos IDH, G6PDH, LAP e MR 


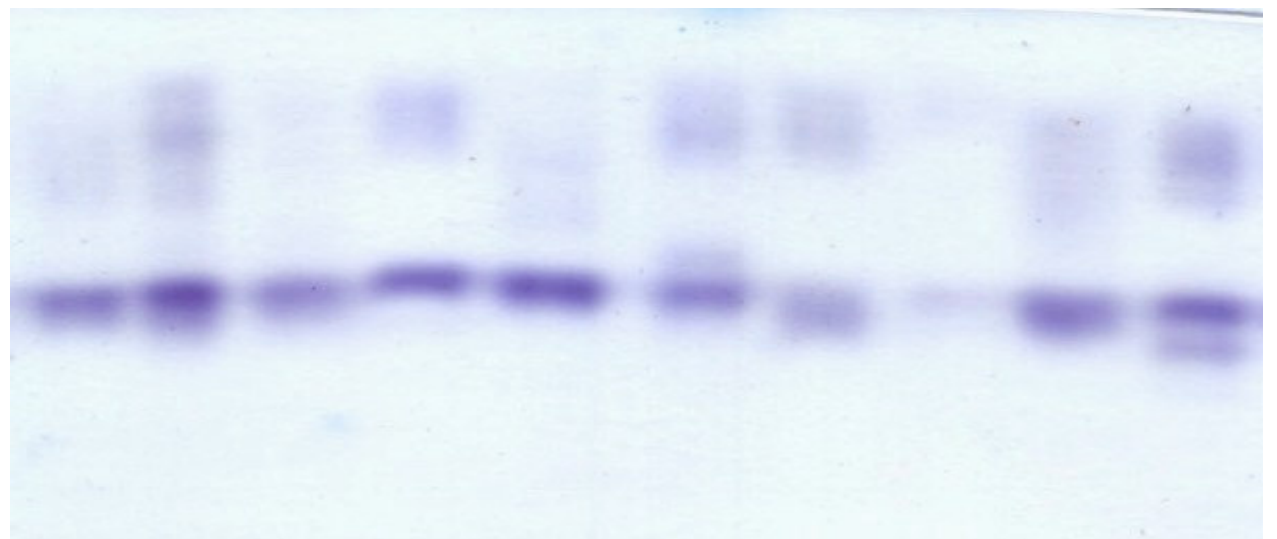

6PGDH

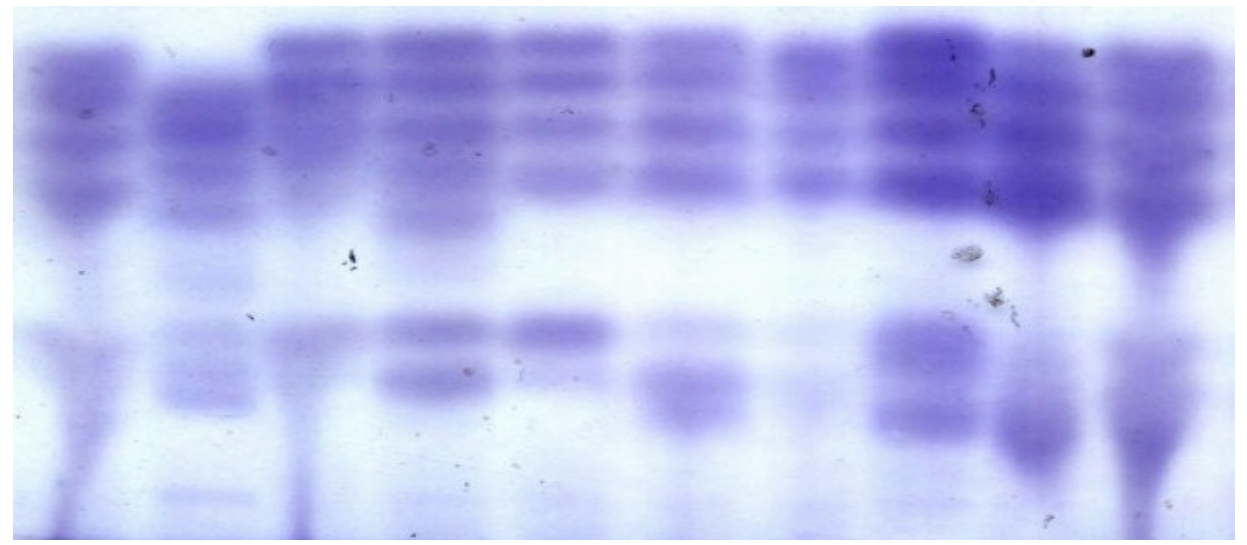

MDH

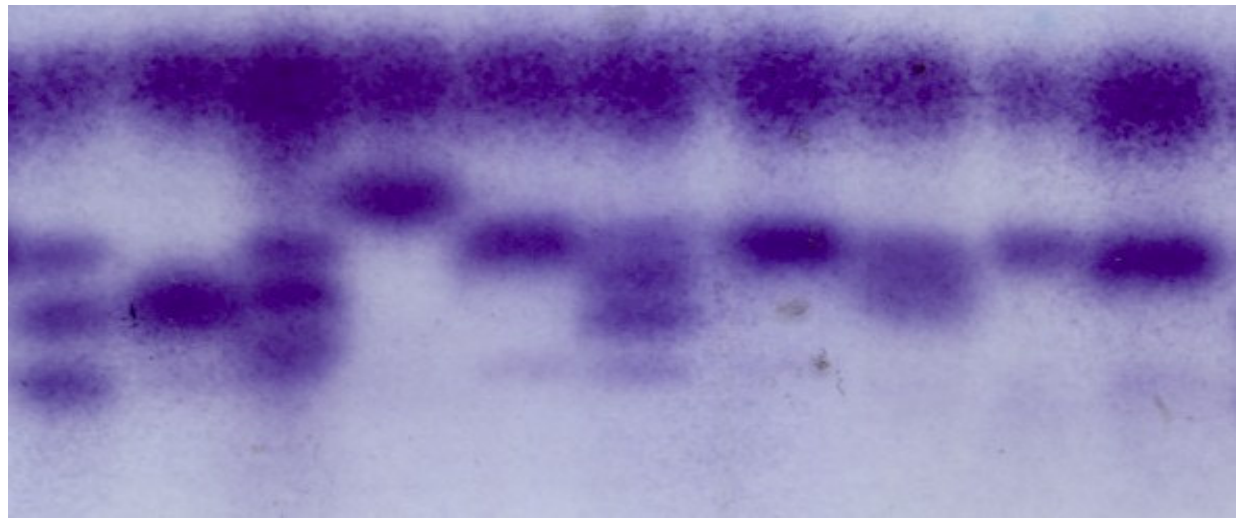

PGI

Figura 3- Padrão de revelação dos sistemas isoenzimáticos 6PGDH, MDH e PGI 
Contudo, devido a problemas de tempo e recursos financeiros para a finalização do projeto, optou-se por uma amostragem mínima de cada procedências, a fim de obterse pelo menos uma idéia do comportamento dos parâmetros do sistema de reprodução em procedências de $M$. scabrella. A presente amostra será futuramente complementada, incluindo todas as progênies por procedências e pelo menos 15 plantas por progênie. $\mathrm{O}$ número total de progênies por procedência, assim como o número de indivíduos, pode ser observado na Tabela 2.

Tabela 2. Número de progênies e de plantas amostradas por procedência de $M$. scabrella, para o estudo do sistema de reprodução

\begin{tabular}{lcc}
\hline \multicolumn{1}{c}{ Procedência } & Número de progênies & Número de plantas \\
\hline Itararé - SP & 10 & 42 \\
Piraí do Sul - PR & 07 & 47 \\
Mandirituba - PR & 12 & 41 \\
Lapa - PR & 09 & 34 \\
Honório Serpa - PR & 11 & 39 \\
Turvo - PR & 12 & 44 \\
Caçador - SC & 09 & 46 \\
Ituporanga - SC (nativa) & 10 & 50 \\
Ituporanga - SC (comercial) & 09 & 41 \\
\hline
\end{tabular}

\subsubsection{Análise Estatística}

O sistema de reprodução de $M$. scabrella foi caracterizado para cada procedência e para o conjunto das procedências, utilizando o modelo misto de reprodução (Ritland \& Jain (1981) e modelo de cruzamentos correlacionados (Ritland, 1989), usando o programa "Multilocos MLTR" (Ritland, 1997). O modelo misto assume que as progênies resultam de uma mistura de autofecundação e cruzamento e o modelo de cruzamentos correlacionados assume que a parte originada de cruzamentos foi gerada parte por cruzamentos aleatórios e parte por cruzamentos biparentais. O modelo de 
reprodução misto de Ritland \& Jain (1981) pressupõem quatro condições: i) a probabilidade de um indivíduo qualquer da procedência cruzar independe de seu genótipo; ii) que os alelos de diferentes locos segregam independentemente; iii) que o conjunto de pólen é homogêneo para o cruzamento com qualquer genótipo da procedência; vi) ausência de seleção entre o período de fertilização e a avaliação da isoenzimas. Os parâmetros estimados dos modelos foram: freqüências alélicas do pólen e dos óvulos, índice de fixação nas árvores maternas $\left(\hat{F}_{m}\right)$ e nas progênies $\left(\hat{F}_{p}\right)$, taxa de cruzamento multilocos $\left(\hat{t}_{m}\right)$, taxa média de cruzamento uniloco $\left(\hat{t}_{s}\right)$, taxa de cruzamento entre parentes $\left(\hat{t}_{m}-\hat{t}_{s}\right)$, correlação de autofecundação $\left(\hat{r}_{s}\right)$ e correlação de paternidade $\left(\hat{r}_{p}\right)$.

O teste de cruzamentos aleatórios foi avaliado comparando a frequiência alélica do pólen e dos óvulos, com base em seu intervalo de confiança a 95\% de probabilidade. O intervalo de confiança foi obtido do erro padrão (SD) da média das frequiências do pólen e óvulo por,

$$
I C_{95 \%}=1,96 \sigma_{p} \sqrt{n}
$$

em que, $\sigma_{p}$ é o desvio padrão da frequiência alélica do pólen e, $n$ é o número de progênies amostradas por procedência.

O teste de desequilíbrio de ligação entre locos foi realizado para cada procedência com base na medida composta de desequilíbrio de ligação de Burrows $\left(\Delta_{i j}\right.$, Weir, 1996), estimada usando o programa GDA (Lewis \& Zaykin, 1999). Esse método é o mais indicado em espécies onde existe a possibilidade de os gametas não se unirem na fertilização de forma aleatória (Weir \& Cockerham, 1984). A hipótese $\mathrm{H}_{0}: \Delta_{i j}=0$ foi testada com o teste de qui-quadrado $\left(\chi^{2}\right)$ proposto por Weir (1996). 
O coeficiente de coancestria $\left(\hat{\theta}_{x y}\right)$ entre plantas dentro de progênies foi estimado pelo coeficiente de correlação de parentesco $\left(\hat{r}_{x y}\right)$ dentro de progênies, conforme derivação de Ritland (1989),

$$
r_{x y}=0,25(1+\hat{F})\left(4 \hat{s}+\left(\hat{t}+\hat{s} \hat{t} \hat{r}_{s}\right)\left(1+\hat{r}_{p}\right)\right]
$$

em que, $\hat{F}$ é o coeficiente de endogamia na geração parental e $\hat{s}$ é a estimativa da taxa de autofecundação $\left(1-\hat{t}_{m}\right)$. Assumindo ausência de parentesco e endogamia na geração parental, o coeficiente de coancestria pode ser estimado do coeficiente de parentesco por:

$$
\hat{\theta}_{x y}=\hat{r}_{x y} / 2
$$

O índice de fixação médio nas progênies $\left(\hat{F}_{p}\right)$ foi estimado com base na fórmula proposta por Weir (1996),

$$
\hat{F}=\frac{\left(\hat{H}_{e}-\hat{H}_{o}\right)+\frac{1}{2 n} \hat{H}_{o}}{\hat{H}_{e}-\frac{1}{2 n} \hat{H}_{o}}
$$

Para verificar se o valor médio de $\hat{F}_{p}$ era diferente de zero, estimou-se o intervalo de confiança a $95 \%$ de probabilidade por reamostragem bootstrap, utilizandose 10.000 reamostragens sobre os locos, usando-se o programa GDA (Lewis \& Zaykin, 1999). Adicionalmente, estimou-se o coeficiente de endogamia esperado a partir da taxa de autofecundação $\left(\hat{F}_{s}\right)$ e pelo cruzamento entre parentes $\left(\hat{F}_{t_{m}-t_{s}}\right)$,

$$
\hat{F}_{s}=0,5 \hat{s}(1+\hat{F})
$$




$$
\hat{F}_{t_{m}-t_{s}}=\hat{F}_{s}-\hat{F}_{p}
$$

O tamanho efetivo de variância médio das progênies foi estimado baseado em Cockerham (1969), assumindo progênies de tamanho infinito:

$$
\hat{N}_{e}=\frac{0,5}{\hat{\theta}_{x y}}
$$

\subsection{Resultados}

\subsubsection{Equilíbrio de ligação}

O teste de desequilíbrio de ligação detectou poucos indícios de ligação entre os locos isoenzimáticos avaliados em M. scabrella (Tabela 3). Dos 189 testes comparando pares de locos foram observados desequilíbrio em apenas oito casos (4,2\%). Dos oito pares de locos mostrando desequilíbrio de ligação, apenas em dois casos os desequilíbrios foram significativos a 99\% de probabilidade. As procedências Piraí do Sul, Honório Serpa, Caçador e Ituporanga comercial não apresentaram nenhum par de locos com indícios de desequilíbrio gamético.

\subsubsection{Freqüiências alélicas do pólen e do óvulo}

Foram observadas diferenças nas frequiências alélicas do pólen e dos óvulos em vários alelos, dos vários locos e em todas as procedências (Tabela 4). Comparando o intervalo de confiança a $95 \%$ de probabilidade das freqüências alélica de pólen e óvulo verificou-se diferenças em 150 dos 260 alelos, o que corresponde a desvios nas freqüências alélicas dos óvulos e pólen em $58 \%$ de todos os alelos avaliados. A análise conjunta de todas as procedências foi a que apresentou o maior número de desvios, com desvios em $89 \%$ dos alelos. Entre procedências, a procedência Piraí do Sul foi a que apresentou menos desvios, (19\% dos alelos) e as procedências Lapa e Honório Serpa o maior número de desvios (69\% dos alelos). 
Tabela 3. Probabilidades do teste de equilíbrio ligação entre sete locos isoenzimáticos em nove procedências de $M$. scabrella.

\begin{tabular}{|c|c|c|c|c|c|c|c|c|c|}
\hline \multirow[t]{2}{*}{ Locos } & \multicolumn{9}{|c|}{ Procedências } \\
\hline & Itararé & Piraí do Sul & Mandirituba & Lapa & Honório Serpa & Turvo & Caçador & $\begin{array}{c}\text { Ituporanga } \\
\text { nativa }\end{array}$ & $\begin{array}{c}\text { Ituporanga } \\
\text { comercial }\end{array}$ \\
\hline$\overline{M r 1 / G 6 p d h}$ & 0,859 & $0,020^{*}$ & 0,867 & 0,734 & 0,426 & 0,570 & 0,677 & 0,299 & 0,060 \\
\hline$M r 1 / M d h 4$ & 0,348 & 0,717 & 0,601 & 0,225 & 0,535 & 0,438 & 0,535 & 0,407 & 0,515 \\
\hline Mrl/Lap & 0,402 & 0,241 & 0,098 & 0,055 & 0,199 & $0,023^{*}$ & 0,999 & 0,201 & 0,569 \\
\hline Mr1/6pgdh2 & 0,828 & 0,366 & 0,336 & 0,382 & 0,978 & 0,729 & 0,387 & 0,662 & 0,621 \\
\hline$M r 1 / I d h 1$ & 0,638 & 0,697 & 0,643 & 0,531 & 0,057 & 0,845 & 0,304 & 0,465 & 0,153 \\
\hline G6pdh/Pgi2 & 0,747 & 0,708 & 0,996 & 0,092 & 0,521 & 0,689 & 0,655 & 0,832 & 0,330 \\
\hline G6pdh/Mdh4 & 0,828 & 0,870 & 0,742 & 0,509 & 0,802 & 0,079 & 0,833 & 0,198 & 0,415 \\
\hline G6pdh/Lap & 0,493 & 0,527 & 0,190 & 0,355 & 0,496 & 0,080 & 0,116 & 0,702 & 0,209 \\
\hline G6pdh/6pgdh2 & 0,922 & 0,058 & 0,134 & 0,460 & 0,540 & $0,038^{*}$ & 0,518 & 0,717 & 0,483 \\
\hline G6pdh/Idh1 & $0,002 * *$ & 0,522 & $0,033 *$ & 0,703 & 0,962 & 0,951 & 0,249 & 0,428 & 0,159 \\
\hline Pgi2/Mdh4 & 0,725 & 0,857 & 0,370 & 0,811 & 0,886 & 0,258 & 0,055 & 0,954 & 0,157 \\
\hline Pgi2/Lap & 0,719 & 0,838 & 0,726 & $0,001^{* *}$ & 0,995 & 0,353 & 0,467 & 0,875 & 0,951 \\
\hline Pgi2/6pgdh2 & 0,785 & 0,433 & 0,187 & 0,300 & 0,549 & 0,412 & 0,168 & 0,416 & 0,953 \\
\hline Pgi2/Idh1 & 0,055 & 0,367 & 0,426 & 0,402 & 0,696 & 0,265 & 0,130 & 0,237 & 0,780 \\
\hline Mdh4/Lap & 0,982 & 0,094 & 0,150 & 0,455 & 0,681 & 0,281 & 0,762 & 0,376 & 0,972 \\
\hline$M d h 4 / 6 p g d h 2$ & 0,056 & 0,123 & 0,937 & 0,097 & 0,446 & 0,538 & 0,621 & 0,887 & 0,308 \\
\hline$M d h 4 / I d h 1$ & 0,395 & 0,071 & 0,571 & 0,540 & 0,376 & 0,078 & 0,196 & 0,146 & 0,781 \\
\hline Lap/6pgdh2 & 0,553 & 0,617 & 0,693 & 0,570 & 0,694 & 0,239 & 0,122 & 0,789 & 0,782 \\
\hline Lap/Idh1 & 0,220 & 0,083 & 0,147 & 0,808 & 0,639 & 0,129 & 0,389 & 0,409 & 0,615 \\
\hline 6pgdh2/Idh1 & 0,442 & 0,243 & 0,560 & 0,209 & 0,339 & 0,780 & 0,318 & 0,102 & 0,389 \\
\hline
\end{tabular}

$* P<0,05 \mathrm{e}^{* *} P<0,01$. 


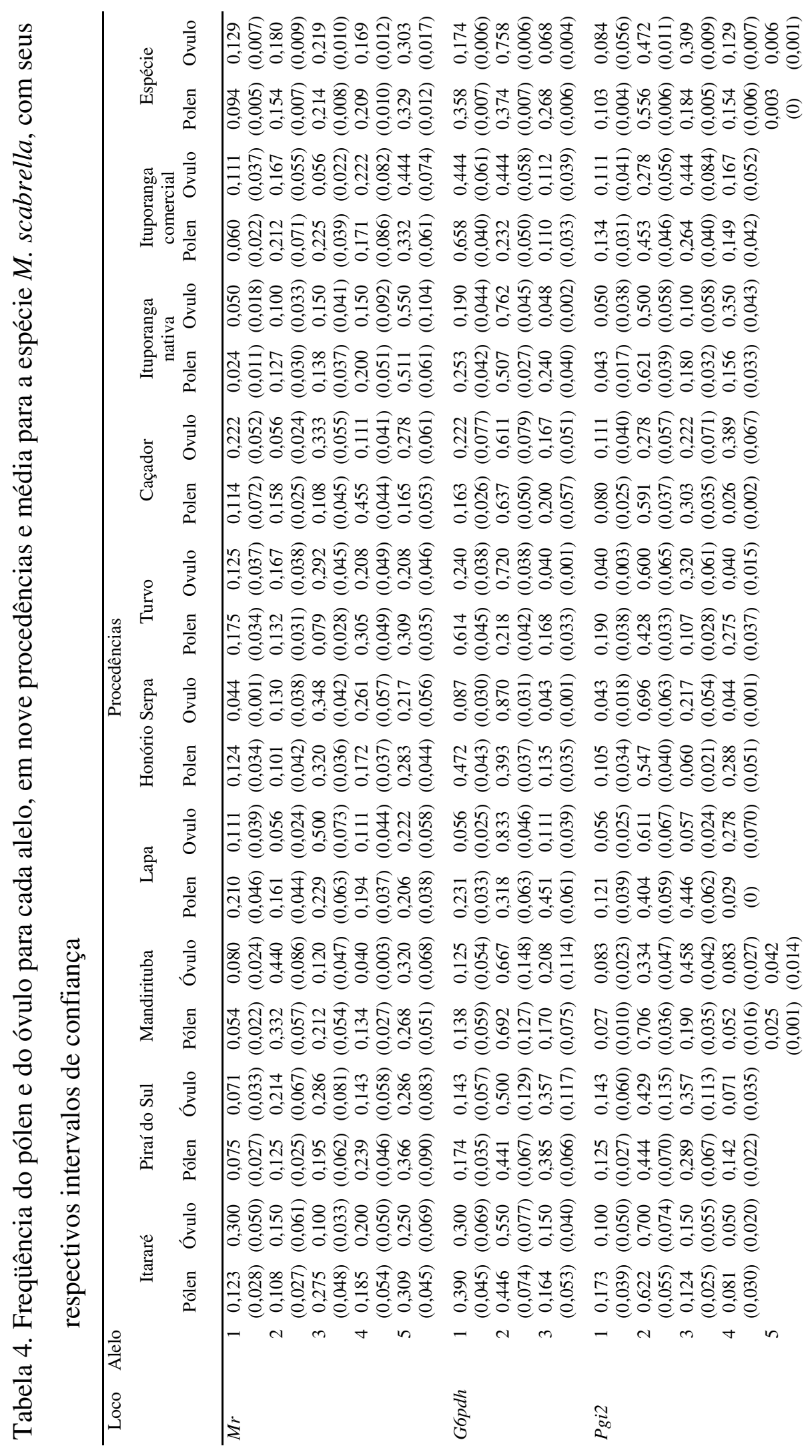




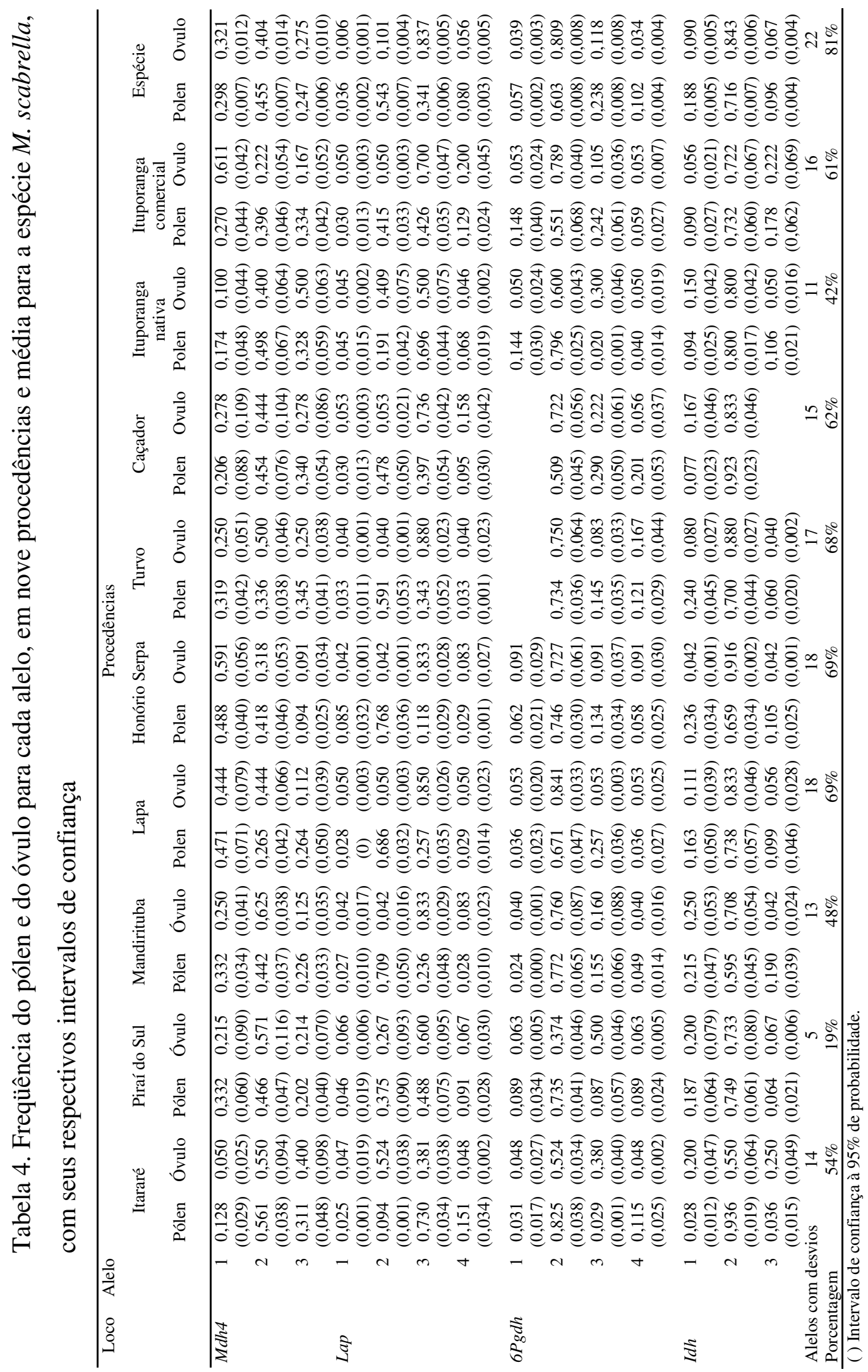




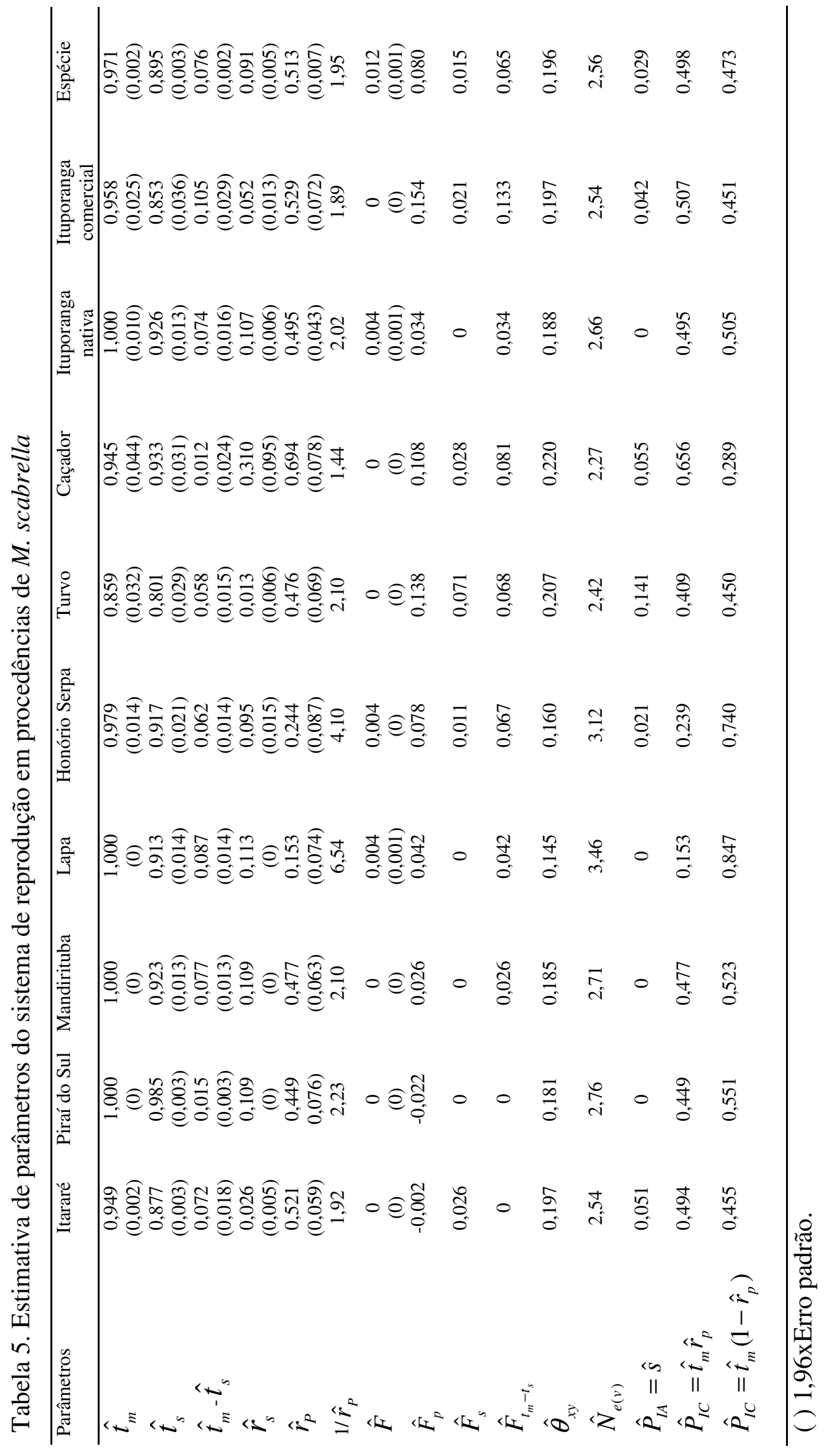




\subsubsection{Taxa de cruzamento}

As estimativas da taxa de cruzamento multilocos $\left(\hat{t}_{m}\right)$ variaram de 0,859 a 1,00 , sendo que, conforme o intervalo de confiança a 95\% de significância, três procedências apresentaram taxa de cruzamento igual a 1,00 (Piraí do Sul, Mandirituba e Lapa) e as demais diferenças significativas da unidade. A taxa de cruzamento para o conjunto das procedências foi alta es estatisticamente diferente de um $(0,971 \pm 0,0025)$ (Tabela 5). As estimativas de taxa de cruzamento unilocos $\left(\hat{t}_{s}\right)$ foram altas e estatisticamente diferentes de um e inferiores. As diferenças entre a taxa de cruzamento multilocos e unilocus $\left(\hat{t}_{m}{ }^{-}\right.$ $\hat{t}_{s}$ ) variaram entre procedências de 0,012 a 0,105 , sendo que apenas a procedência Caçador-SC, não apresentou valor diferente de zero, considerando o intervalo de confiança a $95 \%$ de probabilidade.

\subsection{4 Índices de fixação}

Os índices de fixação nas árvores maternas $(\hat{F})$ não diferiram estatisticamente de zero em seis das nove procedências estudadas (valores variando de zero a 0,004). A estimativa do índice de fixação para as progênies variou de $-0,022$ a 0,154 , sendo significativo apenas nas procedências Caçador $(0,108)$ e Ituporanga comercial $(0,154)$. Comparando o índice de fixação nas árvores adultas com o observado nas progênies verifica-se a tendência das progênies apresentaram maiores valores do que as árvores adultas, sugerindo a possibilidade de estar ocorrendo seleção contra homozigotos entre a fase de plântulas e a fase adulta. Com exceção das procedências Itararé e Piraí do Sul, que apresentaram índice de fixação nas progênies $\left(\hat{F}_{p}\right)$ menores do que zero $(-0,002$ e 0,022, respectivamente), nas demais foi detectado menor coeficiente de endogamia em equilíbrio de endogamia ( $\hat{F}_{e}$ variando de 0 a 0,076 ) do que o calculado nas progênies (variando de 0,026 a 0,154), sugerindo que a apenas parte da endogamia observada nas progênies foi gerada por autofecundação, sendo o restante da endogamia $\left(\hat{F}_{p}-\hat{F}_{e}\right)$ devido provavelmente aos cruzamentos entre parentes. 


\subsubsection{Cruzamentos correlacionados}

A estimativa de correlação de autofecundação $\left(\hat{r}_{s}\right)$ foi baixa, porém significativa, variando entre procedências de 0,013 a 0,310. A estimativa de correlação de paternidade

$\left(\hat{r}_{P}\right)$, que mede a proporção de progênies de cruzamento que são irmãos-completos, foi significativamente diferente de zero em todas as procedências e variou de baixo $(0,153)$ a alto $(0,695)$. Para o conjunto das procedências a correlação de paternidade foi de 0,513. O número de médio de indivíduos polinizadores $\left(1 / \hat{r}_{P}\right)$ foi baixo em todas as procedências, variando de 1,44 a 6,54 (procedências Caçador e Lapa, respectivamente). O coeficiente de coancestria entre plantas dentro de progênies foi maior do que o esperado em progênies de meios-irmãos, variando de 0,145 (Lapa) a 0,440 (Caçador). O tamanho efetivo de variância foi menor do que o esperado em progênies oriundas de uma procedência idealizada (4), com valores variando de 2,27 (Caçador) a 3,46 (Lapa).

As progênies de polinização livre de todas as procedências foram constituídas por misturas de no mínimo meios-irmãos e irmãos-completos (procedências Piraí do Sul, Mandiruba, Lapa e Ituporanga nativa). A procedência Lapa foi a que apresentou características reprodutivas mais próximas as esperadas pelo modelo de cruzamentos aleatórios, com 15,3\% de irmãos-completos e 84,7\% de meios-irmãos. A procedência Caçador foi a que apresentou os maiores desvios no sistema de reprodução com 5,5\% de irmãos de autofecundação, 65,6\% de irmãos-completos e 28,9\% de meios-irmãos. Na maioria das procedências, aproximadamente a metade das progênies era meios-irmãos e a outra metade irmãos-completos.

\subsection{Discussões}

\subsubsection{Equilíbrio de ligação}

Uma das pressuposições básicas do modelo misto de reprodução é a ausência de associação ou ligação entre alelos de diferentes locos. A presença de desequilíbrio de ligação vicia a estimativa de parâmetros em estudos do sistema de reprodução por incluir nas análises informações correlacionadas, gerando estimativas com tendências. $\mathrm{O}$ teste de desequilíbrio de ligação (Tabela 3) detectou poucos indícios de ligação entre os locos 
isoenzimáticos avaliados em M. scabrella, sendo que na maioria das vezes, os desvios foram fracos, de forma que se acredita de tais desvios causem poucos efeitos nas estimativas multiloco de cruzamento. Assim, para o estudo do sistema de reprodução não foram excluídos nenhuns dos locos avaliados em M. escabrella.

Um dos fatores que contribuem para a variabilidade genética nas procedências é a recombinação gênica, também conhecida como segregação dos cromossomos, ocorrida durante a meiose. Esse fenômeno permite a formação de novas combinações de genes através da troca de partes entre cromátides não irmãs de cromossomos homólogos (Valois et al., 1996). Para que a recombinação ocorra de forma eficiente é necessário que os genes envolvidos na permuta estejam em diferentes locos distantes entre si nos locos, ou seja, que esses estejam em estado de equilíbrio de ligação. No caso de desequilíbrio de ligação, os dois locos são herdados juntos, como um loco único (Futuyma, 1997), que não pode ser separado por recombinação cromossômica. A ligação entre dois locos não determina que as características por eles codificadas se correlacionam, apenas impossibilita que eles segregam independentemente. É importante salientar que, devido a taxa de recombinação, presente em cada evento reprodutivo, esses locos ligados caminham para a segregação independente. Quanto menor for a taxa de recombinação, mais gerações de cruzamentos serão necessárias para que se atinja o estado de equilíbrio de ligação (Hartl \& Clark, 1997).

\subsubsection{Freqüências alélicas do pólen e do óvulo}

O teste de homogeneidade detectou diferenças significativas nas frequiências de pólen e óvulo em todas as procedências (Tabela 4). Diferenças foram observadas em 150 dos 260 alelos, o que corresponde a desvios nas freqüências alélicas dos óvulos e pólen em 58\% de todos os alelos avaliados. Desvios nas frequiências alélicas do pólen e dos óvulos em espécies monóicas como M. scabrella podem ser causados pela imigração de pólen de fora da procedência, assincronismo no florescimento, comportamento dos

polinizadores visitando árvores de forma não aleatória, cruzamentos entre parentes e autofecundações. Embora, a homogeneidade nas freqüências alélicas do pólen e dos óvulos seja uma das pressuposições básicas do modelo de cruzamentos mistos de 
Ritland \& Jain (1981), desvios neste sentido, abrem a oportunidade de se estudar outras facetas do sistema de reprodução, como cruzamentos biparentais e endogâmicos. Ainda, segundo Ritland \& Jain (1981), desvios na pressuposição da homogeneidade nas frequiências alélicas do pólen e dos óvulos tem poucos efeitos nas estimativas da taxa de cruzamento multilocos.

\subsubsection{Taxa de cruzamento}

De acordo com as estimativas da taxa de cruzamento multilocos $\left(\hat{t}_{m}\right), M$. scabrella é espécie de sistema misto com predomínio de cruzamentos (Tabela 5). As estimativas da taxa de cruzamento multilocos variaram entre procedências de 0,859 a 1,00 , sendo que, conforme o intervalo de confiança a $95 \%$ de probabilidade, quatro procedências apresentaram taxa de cruzamento igual a 1,00 (Piraí do Sul, Mandirituba, Lapa e Ituporanga nativa) e cinco procedências apresentaram taxa de cruzamento significativamente diferente da unidade. A taxa de cruzamento médio para a espécie foi igualmente alta $(0,971 \pm 0,0025)$, mas estatisticamente diferente de zero. Comparando estes resultados com a estimativa média da taxa de cruzamento multilocos calculado por Sebbenn (2001) para 49 espécies arbóreas tropicais (0,880), verifica-se que $M$. scabrella se reproduz com maior taxa de cruzamento que a média das espécies arbóreas tropicais. Altas taxas de cruzamento favorecem a recombinação e a redução da endogamia. Contudo, é possível que a taxa de cruzamento estimada para as procedências de $M$. scabrella esteja superestimada, devido a possível ocorrência de seleção entre a fase de fertilização e a fase de avaliação das progênies. Como as progênies avaliadas tinham mais de seis meses de idade e passaram por diferentes condições ambientais (viveiro e

plantio no campo) é possível que parte das progênies com endogamia possa ter morrido ou tenha sido eliminada durante o preparo das mudas e plantio, de forma que o material avaliado possa ter sido originado predominantemente de cruzamento. 


\subsubsection{Cruzamento entre parentes}

A taxa de cruzamento entre aparentados $\left(\hat{t}_{m}-\hat{t}_{s}\right)$ variou entre procedências de 0,012 a 0,105, sendo que apenas a estimativa obtida para a procedências Caçador não difere estatisticamente de zero. Tais resultados indicam que ocorreram cruzamentos entre indivíduos parentes dentro das procedências e possível estrutura genética espacial. M. scabrella dispersa suas sementes por autocoria (Carvalho, 1994), portanto, grande parte das sementes são depositada nas vizinhanças da árvore materna, favorecendo a formação de estrutura genética espacial. A estrutura genética espacial pode, por sua vez, favorecer a ocorrência de cruzamentos entre parentes, gerando endogamia na descendência (progênies). Comparando o coeficiente de endogamia obtido da taxa de

autofecundação $\left(\hat{F}_{s}\right)$ com o obtido do cruzamento entre parentes $\left(\hat{F}_{t_{m}-t_{s}}\right)$, verifica-se que na maioria das procedências, a maior parte da endogamia observada nas progênies foi gerada pelo cruzamento entre parentes. Como o coeficiente de endogamia em uma geração corresponde ao coeficiente de coancestria da precedente geração (Lindgren et al., 1997), observado a magnitude do coeficiente de endogamia gerado pelo cruzamento entre parentes pode-se pressupor que a coancestria na procedência Ituporanga comercial está próxima a esperada em progênies de meios-irmãos, ou seja, que o plantio foi realizado a partir de sementes de poucas árvores. Nas procedências Lapa, Honório Serpa, Turvo, Caçador e Ituporanga comercial a magnitude do coeficiente de endogamia sugere que a coancestria encontra-se entre primos de segundo grau $(0,031)$ e primos de primeiro grau (0,0625). O estudo detalhado da estrutura genética espacial das procedências de $M$. scabrella, usando análise de autocorrelação espacial e marcadores genéticos pode desvendar essas hipóteses.

\subsubsection{Taxa de cruzamentos correlacionados}

A estimativa de correlação de autofecundação $\left(\hat{r}_{s}\right)$ foi baixa (variando de 0,013 a 0,310), porém significativa, indicando que, em algumas procedências, existe a tendência de algumas progênies deixarem mais descendentes por autofecundação do que outras, possivelmente devido a variação na auto-incompatibilidade entre e dentro das 
procedências. Aparentemente, a procedência Caçador apresenta maior variação entre árvores na auto-incompatibilidade.

A estimativa de correlação de paternidade $\left(\hat{r}_{P}\right)$ variou de média $(0,153 \pm 0,074$ na procedência de Lapa - PR), à alta $(0,694 \pm 0,078$ na procedência de Caçador - SC), evidenciando que grande proporção das progênies foram geradas por cruzamentos biparentais e são parentes no grau de irmãos completos. A proporção estimada de irmãos-completos variou entre procedências de 0,153 (Lapa) a 0,656 (Caçador). Tais resultados também revelam que o número efetivo médio de árvores polinizando é restrito. $\mathrm{O}$ número de médio de indivíduos polinizadores $\left(1 / \hat{r}_{P}\right)$ variou de 1,44 a 6,54 (procedências Caçador e Lapa, respectivamente). De forma geral, esses resultados são melhor observados nas três últimas linhas da Tabela 5, onde são dadas as proporções de irmãos de autofecundação $\left(\mathrm{P}_{\mathrm{IA}}\right)$, de irmãos completos $\left(\mathrm{P}_{\mathrm{IC}}\right)$, e de meios-irmão $\left(\mathrm{P}_{\mathrm{MI}}\right)$. A procedência que apresentou menor número de parentais envolvidos nos cruzamentos (Caçador - SC) também foi a que obteve maior proporção de irmãos-completos. Por outro lado, a procedência de Lapa (PR), além de não apresentar irmãos por autofecundação, tem a menor porcentagem de irmãos-completos e o maior número efetivo de polinizadores (6,54). Assim, não é possível assumir que progênies coletadas de polinização aberta de procedências de $M$. scabrella são meios-irmãos. Consequientemente, o uso do modelo aleatório, que assume que progênies de polinização aberta são meios-irmãos, para estimativa de parâmetros genéticos e coleta de sementes para programas de melhoramento, conservação genética e recuperação ambiental, pode gerar fortes superestimativas na variância genética aditiva e parâmetros afins, bem como requere maiores tamanhos amostrais do que seriam necessários coletar de populações de espécies que se reproduzem com características próximas a espécies panmíticas.

Em espécies arbóreas tropicais, estudos do sistema de reprodução baseados em marcadores genéticos e nos modelos misto de reprodução e cruzamentos correlacionados vêm revelando que a ocorrência de cruzamentos não aleatórios são, aparentemente, comuns em tais espécies. Por exemplo, em Eucalyptus marginata (Millar et al., 2000) a estimativa da correlação de paternidade variou entre populações de 0,53 a $0, .92$, em 
Cariniana legalis (Mart.) Ktze (Sebbenn et al., 2000a), variou de 0,212 a 0,324, em Dryolanops aromatica Gaertn. (Lee, 2000), variou de 0,107 a 0,428, em Eucalyptus camaldulensis Dehnh (Butcher \& Willians, 2002), variou de 0,079 a 0,365, em Enterolobium cyclocarpum Jacq. (Rocha \& Aguilar, 2001), variou de 0,174 a 0,462, em Caryocar brasiliense Camb. (Dougl. ex Forbes) (Collevattii et al., 2001) variou de 0,042 a 0,205 e em Pachira quinata (Jacq.) Alverson (Fuchs et al., 2003), variou de 0,470 a 0,777. Portanto, na coleta de sementes de polinização aberta de espécies arbóreas tropicais para fins de melhoramento e conservação genética e para reflorestamentos ambientais devem levar em conta a existência de mistura de diversos tipos de parentesco dentro das progênies.

\subsection{6 Índices de fixação}

Os índices de fixação nas árvores maternas $(\hat{F})$ não diferiram estatisticamente de zero em seis das nove procedências estudadas. Nas demais procedências os valores são considerados baixos (máximo 0,012). Por sua vez, com exceção das procedências Itararé e Piraí do Sul, que apresentaram índice de fixação nas progênies negativo, mas não significativos, as demais procedências apresentaram índice de fixação maior do que o estimado para as árvores adultas (variando de 0,026 a 0,154), sugerindo a existência de seleção contra homozigotos entre a fase de plântulas e a fase adulta. Este fenômeno tem sido relatado em diversos estudos comparando diferentes gerações em espécies arbóreas tropicais (Lee et al., 2000; Sebbenn et al., 2000a; 2001a e b; Seoane et al., 2001; Souza et al, 2003; Alves et al., 2003; Gusson et al., 2004).

\subsubsection{Coeficiente de coancestria e tamanho efetivo de variância}

O coeficiente médio de coancestria entre plantas dentro de progênies $\left(\hat{\theta}_{x y}\right)$, apresentou valores acima do esperado em progênies de meios-irmãos $(0,125)$ em todas as procedências avaliadas, com valores variando de 0,145 (Lapa) a 0,220 (Caçador). Portanto, as coancestrias estimadas foram de $14 \%$ a $43 \%$ superiores as esperadas em progênies de meios-irmãos. Na maioria das procedências o valor encontrado estava mais 
aproximou do esperado para progênies de irmãos-completos $\left(\hat{\theta}_{x y}=0,250\right)$, do que propriamente de meios-irmãos. Comparando o coeficiente de coancestria estimado para o conjunto das procedências $(0,196)$, com o estimado para a média de 24 espécies folhosas polinizadas por animas, assumindo ausência de endogamia e parentesco na

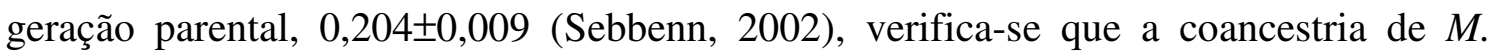
scabrella encontra-se dentro do padrão observado para outras espécies arbóreas.

O conhecimento do coeficiente de coancestria entre plantas dentro de progênies é de fundamental importância em programas de melhoramento genético. A avaliação da herança de caracteres quantitativos em progênies de polinização aberta de espécies com coeficiente de coancestria maior do que o esperado em progênies de meios-irmãos, requerem modelos específicos como, por exemplo, o descrito por Ritland (1989). A variância genética entre progênies de meios-irmãos de populações sem endogamia e parentesco estima $1 / 4$ de variância genética aditiva $\left(\sigma_{p}^{2}=1 / 4 \sigma_{A}^{2}\right)$. O termo $1 / 4$ corresponde ao coeficiente de parentesco entre plantas dentro de progênies $\left(r_{x y}\right)$, que em espécies diplóides corresponde ao dobro do coeficiente de coancestria $\left(r_{x y}=2 \theta_{x y}\right)$. Assim, pode-se estimar a variância genética aditiva entre progênies diretamente do coeficiente de coancestria, $\sigma_{A}^{2}=\sigma_{p}^{2} / 2 \theta_{x y}$. Portanto, considerando o conjunto das procedências de $M$. scabrella, a variância genética aditiva deve ser estimada por $\sigma_{A}^{2}=\sigma_{p}^{2} / 0,394$ e não por $\sigma_{p}^{2}=1 / 4 \sigma_{A}^{2}$ ou $\sigma_{p}^{2}=\sigma_{A}^{2} / 0,25$.

O tamanho efetivo de variância mede a representatividade genética de uma população a partir de suas progênies e é uma medida de grande valor para o monitoramento do potencial evolutivo de populações em programas de melhoramento e conservação genética. O tamanho efetivo de variância de uma população idealizada (tamanho infinito, cruzamentos aleatórios, ausência de seleção, mutação e migração) corresponde a quatro $\left(\hat{N}_{e(v)}=4\right)$. Contudo, desvios das pressuposições que caracterizam a população idealizada causam reduções no tamanho efetivo de variância. Nas procedências de $M$. scabrella, o tamanho efetivo de variância foi sempre inferior ao esperado em progênies da população idealizada, com valores variando de 2,27 a 3,46, ou 
seja, o tamanho efetivo de variância atingiu valores $43 \%$ a $14 \%$ inferior ao esperado em populações panmíticas. Isto implica que maiores tamanhos amostrais serão necessários para a manutenção da variabilidade genética em programas de melhoramento e conservação genética. Por exemplo, com base em Sebbenn (2002; 2003a e b) é possível estimar o número de progênies necessárias para a conservação genética ou início de um programa de melhoramento genético, ou ainda, o número de árvores matrizes que devem ter suas sementes coletadas para programas de reflorestamento ambiental. Suponha que objetivo é iniciar um programa de melhoramento genético de longo prazo para $M$. scabrella, usando uma população base com tamanho efetivo de 150. Pergunta-se qual seria o número de árvores para a coleta de sementes ou o número de progênies necessárias para iniciar o programa. Substituindo o valor do tamanho efetivo requerido (150) e o tamanho efetivo médio de variância estimado para o conjunto das procedências na expressão $\hat{m}=N_{e(\text { referência })} / \hat{N}_{e(v)}$ (Sebbenn, 2002, 2003b), conclui-se que seria necessário coletar sementes em aproximadamente 59 árvores matrizes ou iniciar o programa com pelo menos 59 progênies. 


\section{DIVERSIDADE E ESTRUTURA GENÉTICA EM PROCEDÊNCIAS DE Mimosa scabrella BENTHAN DO BRASIL - GENETIC DIVERSITY AND STRUCUTE IN PROVENANCES OF Mimosa scabrella BENTHAN FROM BRAZIL}

\section{Resumo}

A diversidade e estrutura genética da espécie arbórea tropical Mimosa scabrella foi medida por sete locos isoenzimáticos polimórficos em nove procedências disjuntas da principal área natural de distribuição da espécie no Brasil. M. scabrella tem altos níveis de diversidade genética quando comparada a outras espécies arbóreas tropicas, com número médio de alelos por loco de 3,86, número médio efetivo de alelos por loco de 2,38, heterozigosidade esperada de 0,580 e heterozigosidade observada de 0,530. Entre procedências, a diversidade genética acomodou significantes 2,5\% da variação total. Alto fluxo gênico foi observado $(\hat{N} m=7,7)$, sugerindo que as procedências não estão isoladas. Foi observado índice de fixação de Wright positivo e significativo em duas procedências (Caçador, 0,108; Ituporanga comercial, 0,154), indicando a presença de altos níveis de endogamia. A distância genética de Nei entre as procedências produziu um agregamento próximo ao da localização geográfica das procedências, embora o teste de Mantel $(\hat{r}=0,198, P=0,159)$ indicou ausência de associação significativa entre a distância genética e a distância geográfica entre as procedências. Os altos níveis de diversidade genética podem ser atribuídos a ambos estratégias ecológicas e reprodutivas da espécie. 
Palavras-chave: Isoenzimas, espécies arbóreas tropicais, endogamia, teste de procedências e progênies. 


\section{Summary}

Genetic diversity and structure were measured at seven polymorphic isozyme loci in Mimosa scabrella tropical tree form nine natural disjunct provenances, representing the principal distribution area of the species in Brazil. M. scabrella has high levels of genetic diversity when compared to another tropical tree species, with 3.86 average number of alleles per locus, 2.38 average effective number of alleles per locus, 0.580 expected heterozigosity and 0.530 observed heterozigosity. Among provenance, genetic divergence accounted for a significant $2.5 \%$ of total variation. High gene flow $(\hat{N} m=7.7)$ was observed, suggesting that the provenances it is not isolated. Positive and significant different from zero Wright's gene fixation index were observed in two provenances (Caçador, 0.108; Ituporanga commercial, 0.154), indicating the presence of high levels of inbreeding. Nei's genetic distance among provenance produced close agreement the geographic localization of the provenance, although the Mantel test ( $\hat{r}=0.198, \quad P=0.159)$ indicated absence of significant association between Nei's genetic distance and geographic distance among provenances. The high levels of genetic diversity may be attributable to both the ecological and reproductive strategies of the species.

Key-words: Isozymes, tropical tree species, inbreeding, provenance and progeny test. 


\subsection{Introdução}

Os recursos genéticos florestais são ameaçados por uma ampla gama de fatores, tais como mudanças climáticas, poluição ambiental, destruição de habitats, competição e ataque de pragas. A capacidade das espécies arbóreas em sobreviver a essas ameaças e persistirem em ambientes espacialmente e temporariamente heterogêneos, depende de seu potencial adaptativo, que é determinado pela diversidade genética presente entre e dentro de espécies. A diversidade dentro de espécies, por sua vez, é distribuída entre e dentro de populações. Esta distribuição, em geral não é aleatória, formando padrões onde populações próximas tendem a apresentar níveis mais similares de diversidade genética do que populações localizadas espacialmente distantes. A distribuição da diversidade genética entre e dentro de populações é influenciada por fatores tais como sistema de reprodução, distribuição geográfica, mecanismos de dispersão de sementes e pólen, seleção natural, deriva genética, mutação e característica de histórico de vida, tais como efeito fundador, efeito gargalo, intervenções antrópicas, catástrofes naturais etc. Estudos realizados com espécies arbóreas tropicais relatando estrutura genética são muitos (Moran et al., 1989; Boshier et al., 1995; Chese et al., 1995; Liengsiri et al., 1995; Garay-Arroyo \& Alvarez-Buylla, 1997; Sebbenn et al., 1998a; 2001a e b; Seoane et al., 2000; Moraes et al., 1999; Telles et al., 2001; 2003; Collevati et al., 2001, entre outros). Em geral, o padrão observado indica que a maior parte da diversidade genética encontra-se dentro de populações (Hamrick et al., 1979; Hamrick, 1983; Hamrick \& Godt, 1990). A magnitude da diversidade genética dentro de populações de plantas é influenciada pelas características reprodutivas, ecológicas e de historia de vida das espécies como também pelo histórico recente da população (Hamrick \& Godt, 1990).

Mimosa scabrella Bentham (Leguminosae-Mimosoideae) ou bracatinga é uma espécie arbórea de alta densidade populacional, endêmica da região subtropical brasileira. Sua região de ocorrência natural ocorre entre as latitudes $21^{\circ} 30^{\prime} \mathrm{S}$ (Coronel Pacheco-MG) a 29 40'S (RS), abrangendo os Estados de Minas Gerais (sul), Rio de Janeiro, São Paulo (leste e sul), Paraná (sul e centro sul), Santa Catarina e Rio Grande do Sul (nordeste) em altitudes preferencialmente entre $400 \mathrm{~m}$ a $1.000 \mathrm{~m}$. A espécie é polinizada principalmente por abelhas do tipo Apis e Trigona e tem suas sementes 
dispersas por autocoria, o que favorece a formação de estrutura genética espacial. A espécie tem diversos usos, como madeira serrada e roliça, energia, celulose e papel, goma, substâncias tanantes, produção de mel, reflorestamentos ambientais etc (Carvalho, 1994). Contudo, embora M. scabrella tenha diversas aplicações, praticamente nada se sabe sobre os níveis de diversidade e estrutura genética de suas populações. Segundo Carvalho (1994) as informações existentes restringem-se a um único teste de procedências.

Assim, usando dados de marcadores genéticos do tipo isoenzimas em nove procedências de M. scabrella, os objetivos do presente estudo foram: a) acessar os níveis de diversidade; b) determinar como a diversidade genética está distribuída entre e dentro das procedências e; c) determinar o padrão da relação genética entre as procedências.

\subsection{Material e Métodos}

\subsubsection{Coleta das amostras}

Esse trabalho foi desenvolvido com material genético proveniente de oito procedências naturais e uma comercial, ao longo da distribuição geográfica de $M$. scabrella. Para a escolha das localidades foram consideradas as seguintes observações: existência de procedências conhecidas e bem conservadas; e que as procedências apresentassem um número de matrizes suficiente (aproximadamente, 20 matrizes). Também foi observada a recomendação de Kemp (1976), respeitando uma distância máxima de 1 grau de latitude entre as procedências. Em cada município foi localizada uma procedência, exceto Ituporanga com uma procedência natural e uma comercial. A identificação das procedências e a coleta das sementes foram realizadas por técnicos da EMBRAPA/CNPF entre os anos de 1997 e 1999. A localização dos municípios está descrita na Tabela 1 e demonstrada na Figura 1 (ambas inseridas no capítulo 3). Em cada local (procedência) foram coletadas sementes de 10 a 20 árvores matrizes. De cada árvore foram coletadas sementes suficientes para produção de 50 mudas por progênies. As sementes foram germinadas separadas por progênie no viveiro do Departamento de Ciências Florestais da ESALQ/USP. O teste de procedências e progênies foi instalado em Maio de 2003 na Estação Experimental de Itatinga - ESALQ/USP, município de 
Itatinga-SP (latitudes $23^{\circ} 02^{\prime} 01^{\prime \prime} \mathrm{S}$ e $23^{\circ} 02^{\prime} 30^{\prime} \mathrm{S}$; longitudes $48^{\circ} 38^{\prime} 34^{\prime \prime} \mathrm{W}$ e $48^{\circ}$ 37' 30' ' W; altitude média de $830 \mathrm{~m}$; temperatura média anual de $19,4{ }^{\circ} \mathrm{C}$ e mínima de $12,8{ }^{\circ} \mathrm{C}$; precipitação média de $1.635 \mathrm{~mm}$ e nos mês mais secos (julho) de 30 a $60 \mathrm{~mm}$ ) (Scardua, 1994). O delineamento experimental usado foi o de "Blocos de Famílias Compactas" (Wright, 1978), com nove procedências representando o efeito de parcela, 10 a 20 progênies por procedência, representando o efeito de subparcela, seis plantas por subparcela, em cinco repetições. O espaçamento adotado foi o 3,0 x 1,5 m. O experimento foi rodeado por uma bordadura externa de três linhas.

Para caracterizar os níveis e a distribuição da diversidade genética entre e dentro das procedências a partir de dados de isoenzimas foram coletados tecidos foliares em parte do experimento. Com o intuito de avaliar os efeitos do crescimento das árvores nos níveis de diversidade genética isoenzimática e índice de fixação, foram coletadas amostras, em cada procedência, das 10 plantas com maior altura, das 10 com menor altura, e de 30 plantas aleatórias no restante da procedência (entre as 10 menores e as 10 maiores). Aproximadamente 50 indivíduos foram amostrados por procedência, totalizando 450 plantas no total do ensaio. As folhas foram coletadas, embaladas em sacos plásticos devidamente identificados com o número da árvore de origem e transportadas para o Laboratório de Reprodução e Genética de Espécies Arbóreas (LARGEA/ESALQ/USP), e submetidas imediatamente às análises de eletroforese de isoenzimas.

\subsubsection{Eletroforese de isoenzimas}

O protocolo de extração e revelação das isoenzimas foi desenvolvido com base em Alfenas (1998). Para a extração das isoenzimas de tecidos foliares utilizou-se o tampão de extração número um, citado em Alfenas (1998, pág. 96). Para definição dos sistemas isoenzimáticos, foram testados três sistemas de tampão gel-eletrodo (Citrato Morfolina, Lítio Borato, e Tris Citrato), e 17 sistemas isoenzimáticos. As enzimas que apresentaram melhor atividade de resolução e permitiram a interpretação foram: Fosfogluco Isomerase (PGI-EC 5.3.1.9), Glucose-6-Fosfato Desidrogenase (G6PDHHEC 1.1.1.49), Leucina Aminopeptidase (LAP-EC 3.4.11.1), Malato Desedrogenase 
(MDH-EC 1.1.1.37), Isocitrato Desidrogenase (IDH-EC 1.1.1.42), Menadiona Redutase (MR-EC 1.6.99.2), e a 6-Fosfogluconato Desidrogenase (6PGDH-EC 1.1.1.44). As reações isoenzimáticas foram baseadas em Alfenas (1998). Porém, com a finalidade de melhorar a resolução da enzima Fosfogluco Isomerase (PGI), optou-se pela alteração na quantidade da enzima Glucose-6-Fosfato Desidrogenase de 6,5 $\mu$ l para 7,5 $\mu 1$. Os padrões de revelação dos sistemas isoenzimáticos, assim como, as representações esquemáticas dos fenótipos observados nos zimogramas podem ser observadas nas Figuras 2 e 3 (capítulo 3).

\subsubsection{Análise dos dados}

A estrutura genética das procedências de M. scabrella foi caracterizada pelas frequiências alélicas e pelas estatísticas $F$, estimadas de acordo com o método de Weir \& Cockerham (1984) e usando o programa GDA (Lewis \& Zaykin, 1999).

As freqüências alélicas foram estimadas para as procedências pela expressão,

$$
\hat{p}_{i j}=\frac{n_{i j}}{n_{. j}}
$$

em que:

$\hat{p}_{i j}=$ frequiência do alelo $i$ na procedência $j$;

$n_{i j}=$ número de ocorrência do alelo $i$ na procedência $j$;

$n_{\cdot j}=$ número total de alelos amostrados na procedência $j$.

A análise de variância das freqüências alélicas foi realizada com base em no modelo aleatório hierárquico desbalanceado (Weir, 1996). O modelo estatístico para a análise hierárquica de indivíduos dentro de procedência foi,

$$
Y_{i j k}=m+f_{i}+b_{j(i)}+g_{k(i j)}
$$


em que: $Y_{i j k}=$ freqüência do alelo $k$, dentro do indivíduo $j$, dentro da progênie $i$;

$m$ = média geral das freqüências alélicas;

$f_{i}=$ efeito da procedência $i, \operatorname{com} i=1,2, \ldots, a$;

$b_{j(i)}=$ efeito do indivíduo $j$, dentro da procedência $i$, com $j=1,2, \ldots, b_{i}$;

$g_{k(i j)}=$ efeito do alelo $k$, dentro do indivíduo $j$, dentro da procedência $i$, com $k=1,2, \ldots, n_{i j}$.

Os componentes da variância foram obtidos da Tabela 6, a partir da decomposição das esperanças dos quadrados médios por,

$$
\begin{gathered}
\hat{\sigma}_{G}^{2}=Q M_{G} \\
\hat{\sigma}_{I}^{2}=\frac{Q M_{I}-Q M_{G}}{2} \\
\hat{\sigma}_{p}^{2}=\frac{Q M_{P}-Q M_{I}}{k_{1}}
\end{gathered}
$$

em que: $k_{l}=$ correspondem ao coeficiente das variância entre procedência $\left(\hat{\sigma}_{p}^{2}\right)$ no modelo hierárquico desbalanceado:

$$
k_{1}=\frac{1}{\sum_{i} b_{i}-a}\left[n_{i . .}-\sum_{i} \sum_{j}\left(\frac{n_{i j .}^{2}}{n_{i . .}}\right)\right]
$$


Tabela 6. Esquema da análise da variância de freqüências alélicas no modelo hierárquico desbalanceado para indivíduos dentro de procedência

\begin{tabular}{lccc}
\hline \multicolumn{1}{c}{ FV } & $\mathrm{GL}$ & $\mathrm{QM}$ & \multicolumn{1}{c}{$E(Q M)$} \\
\hline Procedência & $a-1$ & $\mathrm{QM}_{\mathrm{P}}$ & $\sigma_{G}^{2}+2 \sigma_{I}^{2}+k_{l} \sigma_{p}^{2}$ \\
Indivíduos/ procedência & $\sum_{i=1}^{a} b_{j}-a$ & $\mathrm{QM}_{\mathrm{I}}$ & $\sigma_{G}^{2}+2 \sigma_{I}^{2}$ \\
Genes/Indivíduos & $\mathrm{n}_{. .-} \sum_{i=1}^{a} b_{j}$ & $\mathrm{QM}_{\mathrm{G}}$ & $\sigma_{G}^{2}$ \\
\hline Total & $n_{.-1}$ & & \\
\hline
\end{tabular}

O significado genético dos componentes da variância são definidos abaixo:

$$
\begin{gathered}
\sigma_{p}^{2}=p(1-p)\left(\theta_{p}\right) \\
\sigma_{I}^{2}=p(1-p)\left(f-\theta_{p}\right) \\
\sigma_{G}^{2}=p(1-p)(1-f) \\
\sigma_{T}^{2}=\sigma_{p}^{2}+\sigma_{I}^{2}+\sigma_{G}^{2}=p(1-p)
\end{gathered}
$$

em que: $p=$ freqüência de um alelo em um determinado loco; $\hat{\theta}_{p}=$ coeficiente de coancestria média entre plantas dentro de procedência ou divergência genética entre procedência; $\hat{F}=$ correlação entre alelos, dentro de indivíduos de diferentes procedência; $\hat{f}=$ índice de fixação ou correlação entre alelos dentro de indivíduos de mesma procedência.

As estimativas do coeficiente de coancestria e dos índices de fixação foram obtidas dos componentes da variância por:

$$
\hat{\theta}_{p}=\frac{\hat{\sigma}_{p}^{2}}{\hat{\sigma}_{T}^{2}}
$$




$$
\begin{gathered}
\hat{F}=1-\frac{\hat{\sigma}_{g}^{2}}{\hat{\sigma}_{T}^{2}} \\
\hat{f}=\frac{\left(\hat{F}-\hat{\theta}_{P}\right)}{\left(1-\hat{\theta}_{P}\right)}
\end{gathered}
$$

Para verificar se as estimativas médias de $\hat{\theta}_{P}, \hat{F}$, e $\hat{f}$ eram estatisticamente diferentes de zero, estimou-se o intervalos de confiança a $95 \%$ de probabilidade pelo método de reamostragem bootstrap, usando o programa GDA de Lewis \& Zaykin (1999). Utilizaram-se 10.000 repetições sobre os locos.

O fluxo gênico aparente ( $\hat{N} m$ ) entre populações foi estimado de forma indireta, segundo modelo de ilhas proposto por Crow \& Aoki (1984), o qual corrige a análise para pequeno número de populações: $\hat{N} m=(1 / 4 \alpha)\left[\left(1 / \hat{F}_{S T}\right)-1\right]$, em que, $\hat{N}$ corresponde ao tamanho efeito, $m$ ao número de migrantes por geração, $\hat{F}_{S T}$ a divergência genética entre populações e $\alpha$ a correção para o número de populações $(n)$, sendo: $\alpha=[n /(n-1)]^{2}$. A estatística $\hat{F}_{S T}$ foi substituída por $\hat{\theta}_{P}$ conforme sugerem Cockerham e Weir (1993), para uma estimação de fluxo gênico não viesada.

A diversidade genética intrapopulacional foi analisada pela heterozigosidade observada, diversidade gênica esperada segundo o equilíbrio de Hardy-Weinberg, número médio de alelos por loco, porcentagem de locos polimórficos e índice de fixação de Wright, estimativas obtidas a partir do programa BIOSYS-1 (Swofford \& Selander, 1989). A heterozigosidade observada $\left(\hat{H}_{o}\right)$ para cada loco foi obtida por: $\hat{H}_{o}=1-\sum P_{i i}$, em que: $P_{i i}=$ freqüência dos genótipos homozigotos. A diversidade gênica esperada $\left(\hat{H}_{e}\right)$ para cada loco foi obtida segundo Nei (1978) por: $\hat{H}_{e}=1-\sum p_{i}^{2}$, em que: $p_{i}=$ frequiência alélica estimada do i-ésimo alelo. A porcentagem de locos polimórficos $(\hat{P})$ foi estimado pela média aritmética do número total de alelos pelo número de locos, sendo que um loco foi considerado polimórfico quando a freqüência do alelo mais comum não ultrapassava 95\%. O número médio de 
alelos por locos $(\hat{A})$ foi obtido pela divisão do número total de alelos pelo número total de locos. O índice de fixação de Wright $(\hat{f})$ foi estimado em por:

$$
\hat{f}=1-\frac{\hat{H}_{o}}{\hat{H}_{e}}
$$

Para verificar se os valores médios de $\hat{f}$, eram diferentes de zero, estimou-se o intervalo de confiança a $95 \%$ de probabilidade pelo método de reamostragem bootstrap, utilizando-se 10.000 reamostragens sobre os locos, através do programa GDA de Lewis \& Zaykin (1999).

Para entender a estrutura genética hierárquica das procedências de $M$. scabrella foi calculada a distância genética de Nei (1978) e construído o dendrograma usando o método de médias de distâncias entre todos os pares de procedências (UPGMA). As distâncias genéticas e o dendrograma foram obtidos usando o programa TFPGA (Miller, 2000).

Para avaliar a existência de correlação entre as distâncias geográficas e genéticas, aplicou-se o Teste de Mantel entre a matriz de distância genética e a matriz de distância geográfica das procedências, usando o programa TFPGA (Miller, 2000).

\subsection{Resultados}

\subsubsection{Freqüências alélicas}

Foram revelados sete locos polimórficos em sete sistemas isoenzimáticos passíveis de interpretação (Tabela 7). O número médio alelos detectados nos locos foi alto para marcadores isoenzimáticos, variando de três a cinco. O número total de alelos detectados variou entre procedências de 24 a 27. A procedência Mandirituba foi a que apresentou p maior número total de alelos e a procedência de Caçador foi a que apresentou o menor número total de alelos (24). Apenas um alelo exclusivo raro foi detectado na procedência Mandiruba, 0,010 (alelo 5 no loco Pgi-2). 
As freqüências alélicas foram similares entre as procedências (Tabela 7). Nos locos Pgi-2, Lap-1, 6Pgdh-2 e Idh-1, o alelo mais freqüente em uma procedência também foi o mais freqüente nas demais. Por outro lado, no loco $M r-1$, o alelo 5 foi o mais frequiente nas procedências Itararé, Piraí do Sul e Ituporanga natural e comercial, o alelo 2 nas procedências Mandiruba e Caçador e o alelo 3 nas procedências Lapa, Honório Serpa e Turvo. Variação semelhante é observada no loco G6pdh-1 e Mdh-4. Nenhum alelo em nenhuma das procedências apresentou frequiência indicando eminência de fixação $(>0,95)$. O alelo de freqüência mais alta foi o alelo 2 no loco $I d h-1$ da procedência de Caçador (0,905). Essa procedência também não apresentou o alelo 3 no loco Idh-1. Nesse mesmo loco da procedência de Caçador não foi possível encontrar o alelo 3, presente em todas as demais procedências. Ainda, muitos alelos foram detectados como sendo raros $(p<0,05)$. Nas procedências de Turvo (PR) e de Caçador (SC) não foi detectado o alelo 1 do loco $6 P g d h-2$, sugerindo que essas já o perderam, pois as freqüências desse alelo nas outras procedência é baixo.

\subsubsection{Equilíbrio de Hardy-Weinberg}

Com o intuito de conhecer como estava organizada a estrutura genotípica dentro das procedências, testou-se as proporções genotípicas observadas em cada loco nas procedências em relação às proporções esperadas pelo modelo de Equilíbrio de HardyWeinberg (EHW), usando o teste exato de Fisher e a estimativa do índice de fixação para cada loco (Tabela 8). Com exceção da procedência de Ituporanga natural, todas as demais apresentaram desvios das proporções do EHW, em pelo menos dois dos sete locos avaliados, de forma que não é possível assumir que essas procedências estejam em EHW.

\subsubsection{Diversidade genética intrapopulacional}

A diversidade genética foi calculada para cada procedência separadamente e para a espécie como um todo (Tabela 9). Todos os nove locos avaliados eram altamente polimórficos com número de alelos por locos variando de três a cinco como

anteriormente comentado. O número médio de alelos por locos $(\hat{A})$ variou entre 
procedências de 3,43 a 3,86, com média de 3,86 para a espécie. O número médio efetivo de alelos por locos $\left(\hat{A}_{e}\right)$ foi inferior ao número médio de alelos por loco, variando de 2,13 a 2,51, com média de 2,38.

A heterozigosidade esperada $\left(\hat{H}_{e}\right)$ variou entre as procedências de 0,530 a 0,602 , com média de 0,580 (Tabela 9). A heterozigosidade observada ( $\left.\hat{H}_{o}\right)$, por sua vez, variou entre procedências de 0,472 a 0,615, com média de 0,530. 


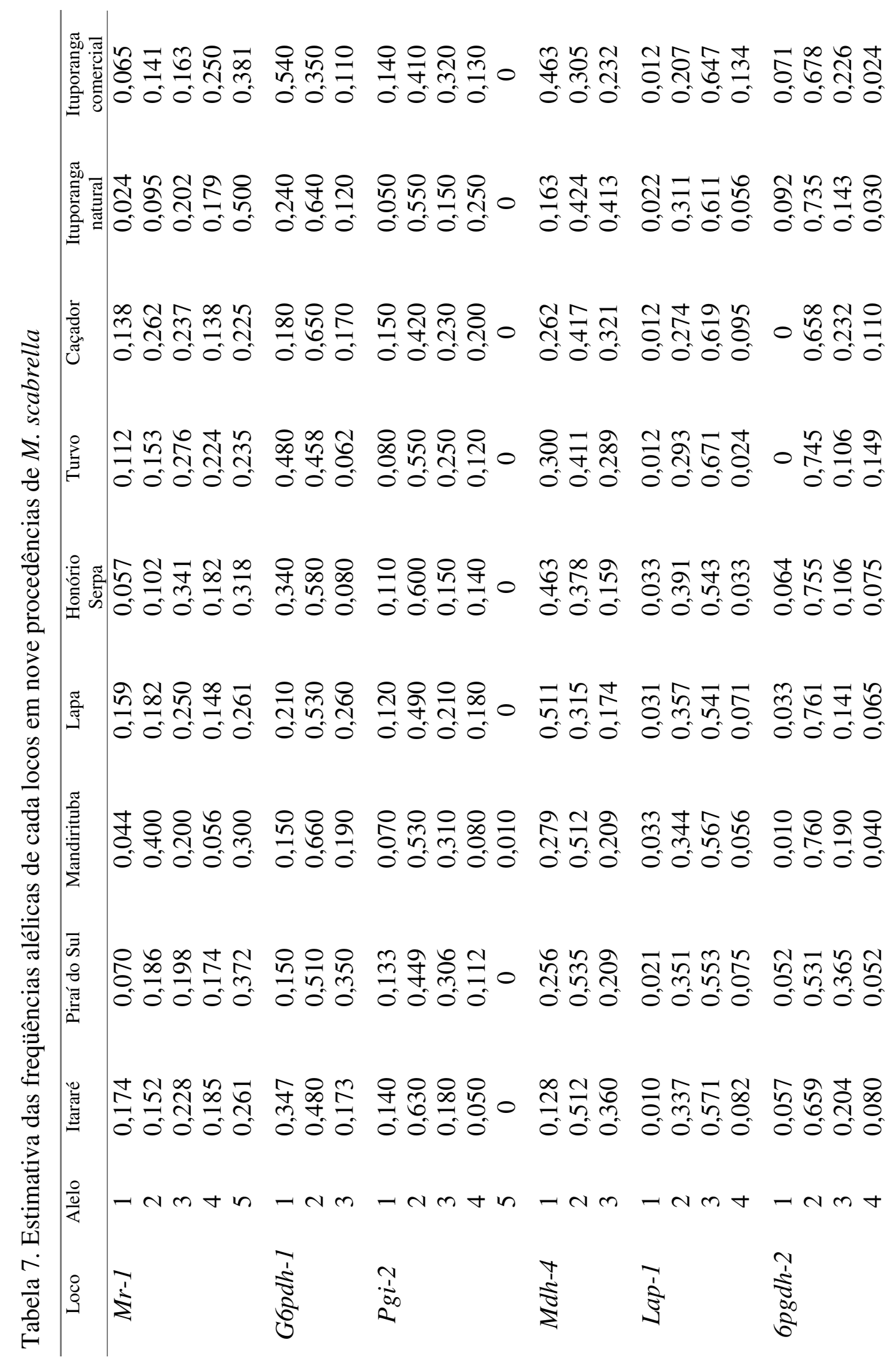




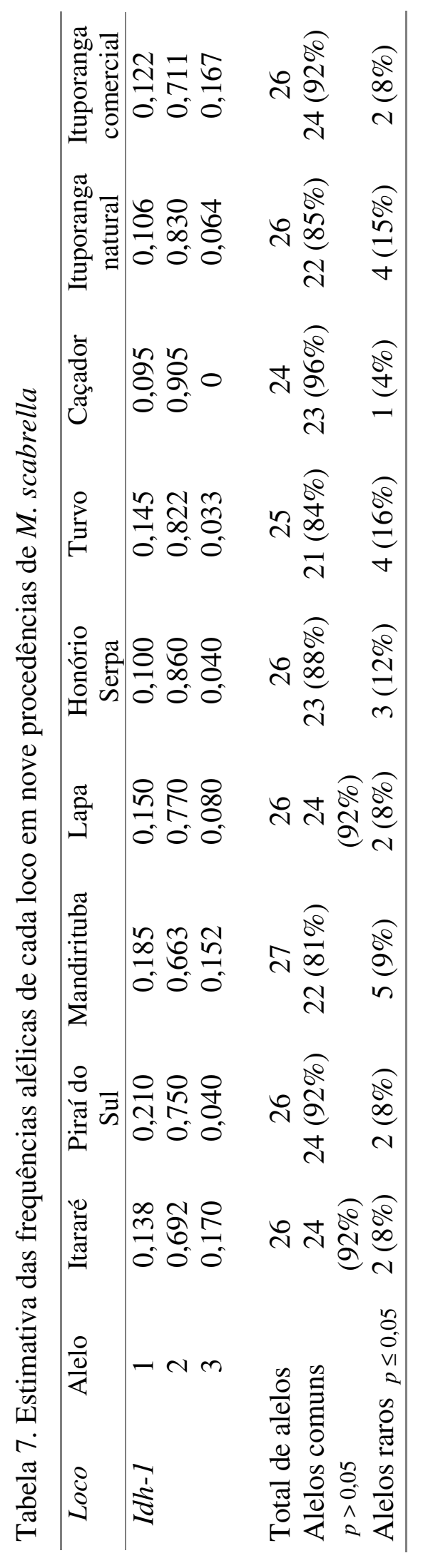


Tabela 8. Estimativa do índice de fixação $(\hat{f})$ para sete locos isoenzimáticos em nove procedências de $M$. scabrella. (A significância estatística do índice $\hat{f}$ foi dada pelo teste exato de Fisher para o Equilíbrio de Hardy-Weinberg)

\begin{tabular}{lccccccc}
\hline Procedência & $M r-1$ & G6pdh & Pgi 2 & Mdh-4 & Lap & 6pgdh-2 & Idh-1 \\
\hline Itararé & $0,242^{* *}$ & $-0,044$ & $-0,048$ & 0,225 & $-0,281^{*}$ & $-0,182$ & $-0,067$ \\
Piraí-do Sul & 0,054 & $-0,087$ & $-0,018$ & $0,280^{* *}$ & $-0,157^{* *}$ & $-0,249^{* *}$ & $-0,010$ \\
Mandiruba & 0,002 & $-0,256^{* *}$ & 0,029 & $0,444^{* *}$ & $-0,228^{* *}$ & $-0,082^{*}$ & $0,190^{*}$ \\
Lapa & 0,176 & $-0,110^{*}$ & 0,023 & $0,509^{* *}$ & $-0,342^{* *}$ & $-0,143$ & 0,058 \\
Honório Serpa & $0,239^{* *}$ & 0,050 & 0,054 & $0,417^{* *}$ & $-0,535^{* *}$ & $0,281^{*}$ & $-0,115$ \\
Turvo & $0,227^{*}$ & $-0,038$ & 0,131 & $0,435^{* *}$ & $-0,304^{* *}$ & 0,133 & 0,274 \\
Caçador & $0,249^{* *}$ & 0,157 & $-0,035$ & $0,175^{* *}$ & $-0,106^{*}$ & $0,135^{*}$ & 0,224 \\
Ituporanga natural & 0,049 & $-0,070$ & 0,059 & 0,069 & $-0,002$ & $-0,033$ & 0,220 \\
Ituporanga Comercial & 0,073 & $0,243^{* *}$ & 0,0289 & 0,057 & $0,216^{* *}$ & 0,075 & $0,516^{* *}$ \\
\hline
\end{tabular}

* $P<0,05$; ** $P<0,01$.

Tabela 9. Estimativas de índices de diversidade genética e índice de fixação em nove procedências de M. scabrella. ( $n$ é o tamanho da amostra; $\hat{A}$ é o número médio de alelos por loco; $\hat{A}_{e}$ é o número médio efetivo de alelos por locos; $\hat{H}_{e}$ é a heterozigosidade esperada; $\hat{H}_{o}$ é o heterozigosidade observada; $\hat{f}$ é o índice de fixação)

\begin{tabular}{lcccccc}
\hline \multicolumn{1}{c}{ Procedência } & $n$ & $\hat{A}$ & $\hat{A}_{e}$ & $\hat{H}_{e}$ & $\hat{H}_{o}$ & $\hat{f}$ \\
\hline Itararé & 47 & 3,71 & 2,45 & 0,591 & 0,592 & $-0,002$ \\
Piraí do Sul & 47 & 3,71 & 2,51 & 0,602 & 0,615 & $-0,022$ \\
Mandirituba & 47 & 3,86 & 2,28 & 0,561 & 0,546 & 0,026 \\
Lapa & 48 & 3,71 & 2,38 & 0,581 & 0,556 & 0,042 \\
Honório Serpa & 47 & 3,71 & 2,14 & 0,532 & 0,491 & 0,078 \\
Turvo & 46 & 3,57 & 2,21 & 0,547 & 0,472 & 0,138 \\
Caçador & 43 & 3,43 & 2,27 & 0,559 & 0,500 & $0,108^{*}$ \\
Ituporanga (nativa) & 47 & 3,71 & 2,13 & 0,530 & 0,512 & 0,034 \\
Ituporanga (comercial) & 45 & 3,71 & 2,45 & 0,593 & 0,502 & $0,154^{* *}$ \\
\hline Espécie & 418 & 3,86 & 2,38 & 0,580 & 0,530 & 0,080 \\
\hline
\end{tabular}

* $P<0,05$; ** $P<0,01$. 


\subsubsection{Estrutura genética e índice de fixação}

O índice de fixação dentro das procedências $(\hat{f})$ variou de $-0,022$ a 0,154 (Tabela 9). Nas populações Itararé e Piraí do Sul o índice de fixação foi negativo (-0,002 e $-0,022$, respectivamente), indicando excesso de heterozigotos, embora os valores não sejam estatisticamente diferente de zero. Nas demais procedência, o índice de fixação foi positivo, mas significativo apenas nas procedências Caçador $(0,108)$ e Ituporanga comercial $(0,154)$, indicando a presença de endogamia. A média aritmética do índice de fixação entre procedências foi positiva, mas não significativo (Tabela 9), sugerindo que na média, as procedências encontram-se em EHW. O mesmo resultado foi observado na média ponderada do índice de fixação entre procedências, 0,060 (Tabela 10). Por sua vez, o índice de fixação estimado para a média do conjunto das procedências $(\hat{F})$ foi negativo, baixo e não significativo (-0,004), confirmando a hipótese de EHW.

A média entre locos na divergência genética entre procedências $\left(\hat{\theta}_{p}\right)$ foi baixa (0,025), mas estatisticamente diferente de zero, mostrando que a maior parte da diversidade genética encontra-se dentro das procedências (97,5\%). A divergência genética variou entre locos de 0,013 a 0,056. A estimativa do fluxo gênico aparente ( $\hat{N} m$ ) entre procedências foi alta, variando entre locos de 3,33 (G6pd) a 98,57 (Lap), com média entre locos de 7,7, sugerindo que as procedências não estão isoladas..

\subsubsection{Distâncias genéticas}

Os valores da distância genética de Nei (1978) entre pares de procedências variaram de 0,005 (Lapa vs Honório Serpa) a 0,074 (Mandiruba vs Ituporanga natural) (Tabela 11). O dendrograma mostrando a relação entre as procedências produziu dois grandes grupos. O grupo um constituído pela procedência Ituporanga comercial e o outro, constituído pelas demais procedências. Esse último grupo apresentou duas subdivisões, a primeira constituída pelas procedências Piraí do Sul e Mandiruba, e o outro constituído pelas procedências Itararé, Lapa, Honório Serpa, Turvo, Caçador e Ituporanga nativa. Contrastando o dendrograma (Figura 4) com a Figura 1, demonstrando a distribuição geográfica das procedências, observa-se uma certa 
coerência entre ambos, sugerindo que procedências mais próximas entre si possam apresentar menor distância genética do que procedências localizadas espacialmente distantes, com exceção das procedências Itararé e Honório Serpa, que se encontram espacialmente distantes, mas agrupadas no dendrograma. Contudo, o teste de mantel (Figura 5), correlacionando a matriz de distância genética de Nei (1978) e o logaritmo natural da distancia geográfica entre procedências foi positivo, mas baixo $(0,198)$ e não significativo $(0,159)$, sugerindo ausência de associação entre a distância genética e a distância geográfica das procedências.

Tabela 10. Estimativas das estatísticas $F$, com base no modelo de Weir \& Cockerham (1984), entre nove procedências de $M$. scabrella. ( $\hat{f}$ é o índice de fixação médio dentro das procedências; $\hat{F}$ é o índice de fixação para o conjunto das procedências; $\hat{\theta}_{p}$ é a divergência genética entre procedências; $\hat{N} m$ é a medida de fluxo gênico aparentes entre procedências)

\begin{tabular}{lcccc}
\hline Loco & $\hat{f}$ & $\hat{F}$ & $\hat{\theta}_{p}$ & $\hat{N} m$ \\
\hline Mrl & 0,150 & 0,166 & 0,019 & 10,20 \\
G6pd & $-0,017$ & 0,040 & 0,056 & 3,33 \\
Pgi2 & 0,024 & 0,038 & 0,014 & 13,91 \\
Mdh4 & 0,291 & 0,317 & 0,037 & 5,14 \\
Lap & $-0,202$ & $-0,199$ & 0,002 & 98,57 \\
6pgdh2 & $-0,019$ & 0,003 & 0,022 & 8,78 \\
Idh1 & 0,140 & 0,157 & 0,020 & 9,68 \\
& & & & \\
Média & 0,060 & 0,083 & 0,025 & 7,70 \\
IC-superior & 0,172 & 0,195 & 0,037 & 15,00 \\
IC-inferior & $-0,057$ & $-0,004$ & 0,013 & 5,14 \\
\hline
\end{tabular}


Tabela 11. Distâncias genéticas de Nei (1978) entre pares de procedências de $M$. scabrella

\begin{tabular}{lcccccccc}
\hline & $\begin{array}{c}\text { Piraí do } \\
\text { Sul }\end{array}$ & $\begin{array}{c}\text { Mandi- } \\
\text { rituba }\end{array}$ & $\begin{array}{c}\text { Lapa } \\
\text { Serpa }\end{array}$ & $\begin{array}{c}\text { Honório } \\
\text { Servo }\end{array}$ & Caçador & $\begin{array}{c}\text { Ituporanga } \\
\text { nativa }\end{array}$ & $\begin{array}{c}\text { Ituporanga } \\
\text { comercial }\end{array}$ \\
\hline Itararé & 0,030 & 0,030 & 0,041 & 0,034 & 0,014 & 0,026 & 0,023 & 0,050 \\
Piraí do Sul & & 0,023 & 0,033 & 0,051 & 0,054 & 0,020 & 0,039 & 0,064 \\
Mandirituba & & & 0,026 & 0,041 & 0,046 & 0,034 & 0,040 & 0,074 \\
Lapa & & & 0,005 & 0,026 & 0,018 & 0,041 & 0,037 \\
Honório Serpa & & & & 0,011 & 0,023 & 0,028 & 0,038 \\
Turvo & & & & & 0,020 & 0,031 & 0,020 \\
Caçador & & & & & & 0,016 & 0,056 \\
Ituporanga natural & & & & & & & 0,061 \\
\hline
\end{tabular}

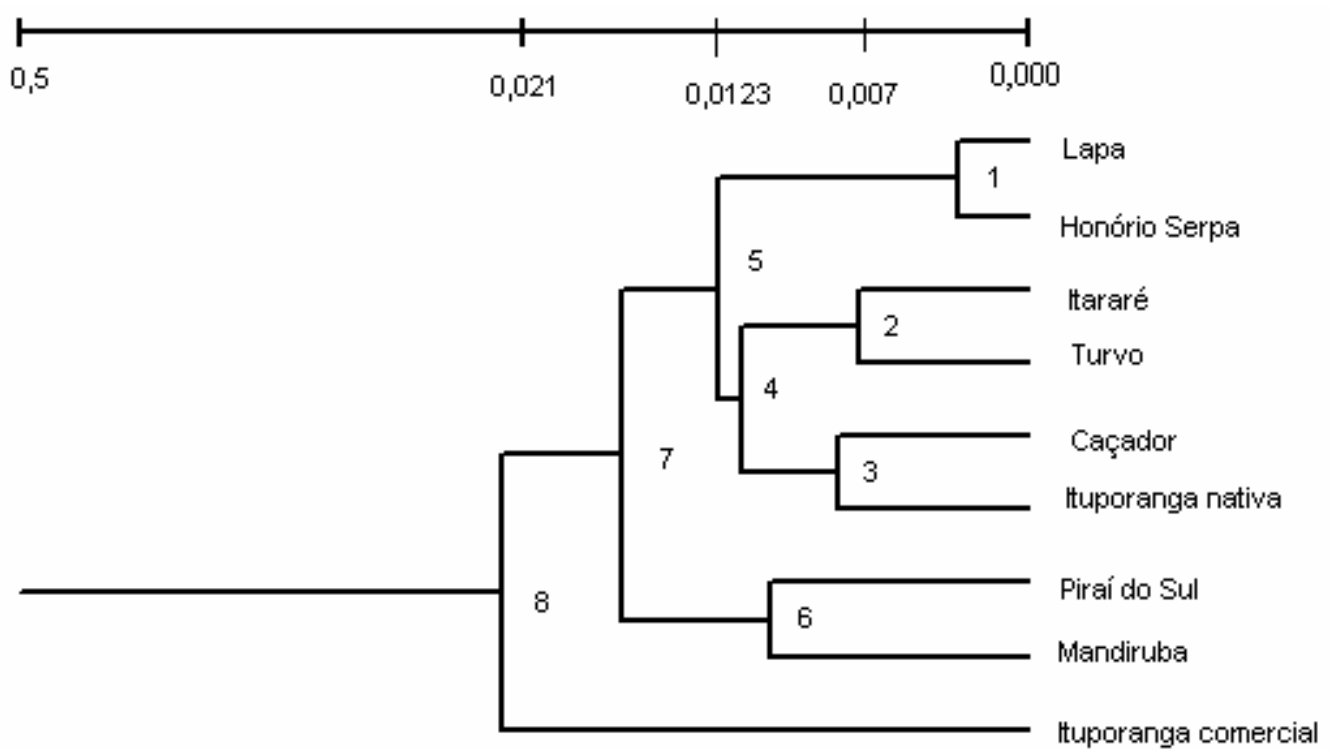

Figura 4- Dendrograma demonstrando a estrutura hierárquica de relação genética entre procedências de M. scabrella. (Os agrupamentos foram produzidos usando o método de médias de distâncias entre todos os pares de grupos (UPGMA) aplicado sobre a matriz de distância genética de Nei, 1978) 


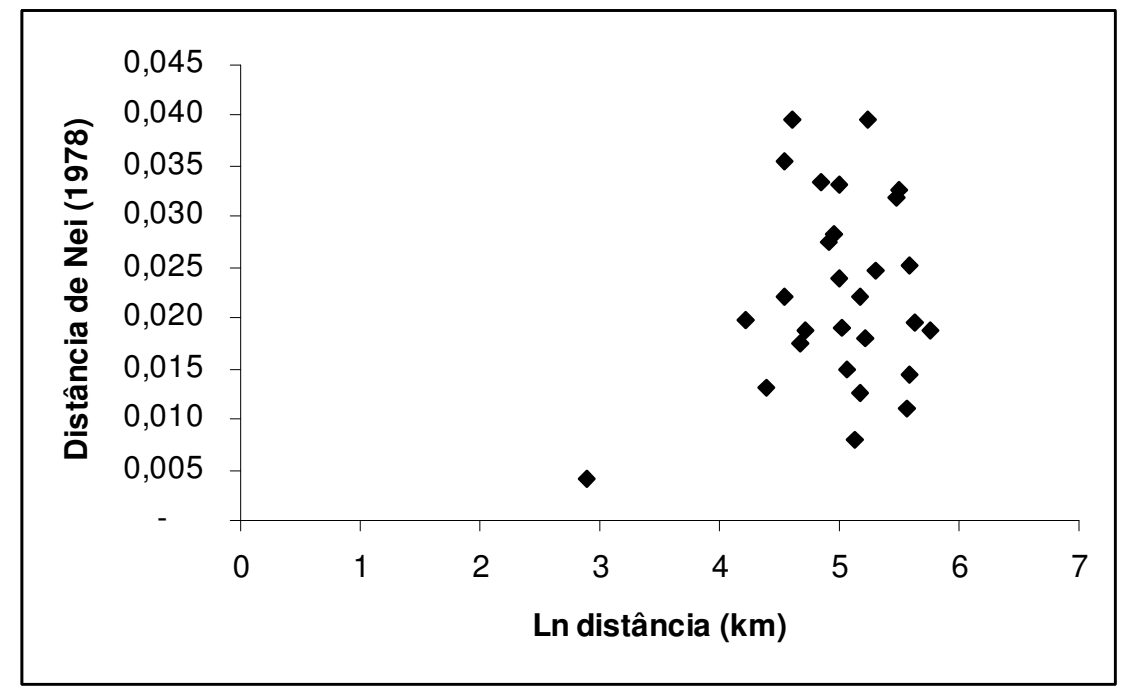

Figura 5- Demonstração gráfica da relação entre a distância genética de Nei (1978) e o logaritmo natural da distância geográfica $(\mathrm{km})$ entre as procedências de $M$. scabrella $(\hat{r}=0,198, P=0,159)$

\subsection{Discussões}

\subsubsection{Equilíbrio de Hardy-Weinberg}

Com exceção da procedência Ituporanga natural, todas as demais apresentaram desvios das proporções do EHW, em pelo menos dois dos sete locos avaliados (Tabela 8). Desvios do EHW podem ser atribuídos cruzamentos não aleatórios (autofecundações, cruzamentos endogâmicos) ou a fatores evolutivos como seleção, mutação, migração e deriva genética. Os desvios foram causados por excesso de homozigotos nos locos $\mathrm{Mr}-1$ (Itararé), G6pdh (Ituporanga comercial), Mdh-4 (Pirai do Sul, Mandiruba, Lapa, Honório Serpa, Turvo e Caçador), Lap (Ituporanga comercial), 6pgdh-2 (Honório Serpa e Caçador) e Idh-1 (Mandiruba e Ituporanga comercial), como demonstrado pelo índice de fixação (Tabela 8) positivos e estatisticamente diferentes de zero. O excesso de homozigotos pode ser atribuído à endogamia advinda de autofecundações e cruzamentos endogâmicos (capítulo 3). Por outro lado, nos demais locos mostrando desvios significativos do EHW, a causa foi o excesso de heterozigotos (G6pdh, Mandiruba; Lap, Piraí do Sul, Mandiruba, Lapa, Honório Serpa, Turvo, Caçador; 6pgdh-2, Piraí do Sul, Mandiruba) como demonstrado pelo índice de fixação negativo (Tabela 8). O excesso de 
heterozigotos pode ter sido causado pela seleção natural, a favor de heterozigotos. Seleção para heterozigotos entre a fase de plântula e a fase adulta tem sido detectada em diversos estudos com espécies arbóreas baseados em dados de isoenzimas como, por exemplo, em Pinus ponderosa (Linhart et al., 1981), Pseudotsuga menziensii (Shaw \& Allard, 1982), Eucalyptus rhodantha (Sampson et al., 1989), Genipa americana (Sebbenn et al., 1998b), Metrosideros excelsa (Schimidt-Adams et al., 2000), Cariniana legalis (Sebbenn et al, 2001a). Assim, as populações de M. scabrella podem gerar progênies parcialmente endogâmicas e a seleção natural, provavelmente, atuem no sentido de reduzir, senão toda, parte da endogamia.

\subsubsection{Diversidade genética intrapopulacional}

O número médio efetivo de alelos por locos $\left(\hat{A}_{e}\right)$ foi menor do que o número médio de alelos por locos $(\hat{A})$. A causa é presença de grande número de alelos raros nos locos. Alelos raros contribuem pouco para as estimativas baseadas em frequiências alélicas como número efetivo de alelos por locos e heterozigosidade esperada em EHW. Esses estimadores dependem mais da frequiência dos alelos comuns. Por exemplo, a procedência Mandiruba encontrava-se entre as procedências com menor número efetivo de alelos por loco, embora seja a procedência com maior número médio de alelos por locos $(3,86)$ e número total de alelos (27). Porém, nove dos 27 alelos (33\%) tinham freqüência inferior a $10 \%(0,1)$, o que fez com que esses contribuíssem pouco para as medida.

Comparando os níveis dos índices de diversidade observados para a média das procedências de M. scabrella (Tabela 9) com os detectados para locos isoenzimáticos em cinco espécies arbóreas tropicais brasileiras por Kageyama et al. (2003) ( $\hat{A}$ variando

de 2,1 a 3,$4 ; \hat{H}_{e}$ variando de 0,255 a 0,$480 ; \hat{H}_{o}$ variando de 0,132 a 0,446$)$, verifica-se que a espécie apresenta altos níveis de diversidade genética. Ainda, comparando a heterozigosidade esperada de $M$. scabrella com a média detectada em espécies arbóreas tropicais comuns, 0,211 (Hamrick \& Loveless, 1989), confirma-se os altos níveis de diversidade presentes na espécie. $M$. scabrella tem características que contribuem para a 
existência de altos níveis de diversidade genética, como apresentar alta densidade populacional em condições naturais. A alta densidade populacional favorece, adicionalmente ao fato de tratar-se de espécie arbórea de vida longa (vive mais de 10 anos), a ocorrência de mutações, as quais muitas podem ser indesejáveis (deletérias), mas muitas podem ser favoráveis (tem algum valor evolutivo ou adaptativo) ou serem neutras (sem valor adaptativo aparente).

Comparando as procedências de M. scabrella observa-se que a Piraí do Sul apresenta os maiores índices $\hat{A}_{e}, \hat{H}_{e}$ e $\hat{H}_{o}$ e a Ituporanga nativa os menores índices $\hat{A}_{e}$ e $\hat{H}_{e}$, e Turvo menor $\hat{H}_{o}$. Em termos de número efetivo de alelos por locos e heterozigosidade observada, as procedências localizadas ao norte da distribuição natural da espécie tende a apresentar maiores valores, relativamente às localizadas ao sul, portanto, essas procedências também seriam as mais indicadas para a conservação genética in situ e ex situ bem como as mais adequadas para a coleta de sementes para programas de melhoramento genético.

A procedência Ituporanga comercial apresentou maiores valores para os índices $\hat{A}_{e}$ e $\hat{H}_{e}$, comparada a procedência Ituporanga nativa (Tabela 9). A causa dos maiores índices $\hat{A}_{e}$ e $\hat{H}_{e}$ pode ser atribuída ao menor número de alelos raros na procedência comercial (apresentou 2 alelos raros), comparativamente a procedência nativa (apresentou 4 alelos raros) (Tabela 7). Dois alelos que eram raros na procedência Ituporanga nativa (alelo 1 no loco $M r-1, \mathrm{p}=0,024$; alelo 5 no loco Pgi-2, $p=0,05$ ) apresentaram maior freqüência na procedência Ituporanga comercial (alelo 1 no loco $M r-1, \mathrm{p}=0,065$; alelo 5 no loco $P g i-2, p=0,14)$. Aumento na freqüência de outros alelos não raros $(p>0,05)$ também pode ser observado, comparando ambas as procedências. Em geral, a procedência Ituporanga comercial apresentou frequiência alélicas mais próxima a esperada pela média aritmética do número de alelos segregando nos locos $\left(1 / n_{a}\right.$, sendo $n_{a}$ o número de alelos em cada loco), o que levou essa procedência a apresentar maiores níveis de diversidade genética nos índices comparada a procedência Ituporanga nativa. Contudo, a heterozigosidade observada $\hat{H}_{o}$, ou a freqüência média de genótipos 
heterozigotos foi maior na procedência Ituporanga natural $(0,512)$, comparada a Ituporanga comercial $(0,502)$. Por outro lado, a heterozigosidade observada foi menor do que a esperada em EHW em ambas as procedências (Tabela 7), mas a diferença entre elas foi maior na procedência comercial, gerando um índice de fixação positivo e estatisticamente diferente de zero $(\hat{f}=0,154)$, indicando a presença de forte endogamia no plantio avaliado.

\subsection{3. Índice de fixação}

O índice de fixação foi positivo na grande maioria das procedências, embora tenha sido significativo apenas nas procedências Caçador $(0,108)$ e Ituporanga Comercial $(0,154)$. Índices de fixação positivos e significativos sugerem que as procedências de Caçador e de Ituporanga comercial apresentam excesso de homozigotos, possivelmente como resultado da ocorrência de autofecundação e cruzamentos endogâmicos. No caso da procedência Ituporanga comercial, a causa do alto índice de fixação pode estar associada ao processo de domesticação. As sementes que deram origem ao plantio podem ter sido colhidas de uma pequena vizinhança genética (árvores próximas), onde existia forte estrutura genética espacial e ocorreu o cruzamento entre indivíduos aparentados. M. scabrella ocorre naturalmente em alta densidade populacional e tem suas sementes dispersas, em grande parte, nas vizinhanças da árvore materna, o que favorece a formação de estrutura genética espacial e a posterior cruzamento entre indivíduos parentes, gerando endogamia na descendência. Isto também explicaria a endogamia detectada na procedência de Caçador. Contudo, a estrutura genética espacial de $M$. scabrella ainda não foi acessada, permanecendo, assim, um campo fértil para estudos posteriores da dinâmica da endogamia entre gerações de $M$. scabrella.

Considerando que a endogamia em uma geração corresponde a coancestria da geração parental $\left(f=\theta_{x y}\right)$ e assumindo, para fins de simplificação, que toda a endogamia gerada por autofecundação foi eliminada pela seleção natura, através da depressão por endogamia, permanecendo somente a endogamia advinda de cruzamentos 
entre indivíduos parentes, poderia-se afirmar que a coancestria na geração parental $\left(\theta_{x y}=0,154\right)$ que deu origem ao plantio comercial, aproxima-se da esperada em indivíduos meios-irmãos $(0,125)$. Em outros termos, significa que o plantio pode ter sido gerado a partir de sementes coletadas do cruzamento entre meios-irmãos. A coleta de sementes em um prévio plantio estabelecido a partir de sementes de uma ou poucas árvores explicaria a endogamia observada no plantio comercial de Ituporanga.

Outras hipóteses para a forte endogamia observada na procedência Ituporanga comercial poderia ser a de que as sementes foram coletadas de árvores isoladas ou em árvores onde ocorreu alta taxa de autofecundação.

\subsubsection{Estrutura genética e fluxo gênico}

A análise da distribuição da diversidade genética entre e dentro de procedências indicou que apenas 2,5\% da diversidade genética total encontra-se entre procedências e, portanto, a maior parte encontra-se dentro de procedências. $\mathrm{O}$ padrão de estrutura genética com maior parte da diversidade distribuída dentro das procedências ou populações é coerente com o padrão esperado em espécies que se reproduzam predominantemente por cruzamento, tem vida longa ( $>10$ anos), alta densidade populacional e eficientes mecanismos de dispersão sementes e pólen, como a $M$. scabrella. Maior diversidade genética dentro de populações, relativamente a presente entre populações tem sido observada na grande maioria dos estudos conduzidos com marcadores genéticos em espécies arbóreas tropicais, podendo citar como exemplo os estudos com Cordia alliodora (R. and P.) Oken ( $\hat{G}_{S T}=0,117$, Chese et al., 1995), Pterocarpus macrocarpus Kurz. ( $\hat{F}_{S T}=0,117$, Liengsiri et al., 1995) Cryptocarya moschata Nees $\left(\hat{\theta}_{P}=0,123\right.$, Moraes et al., 1999), Esenbeckia leiocarpa Engl. $\left(\hat{\theta}_{P}=0,121\right.$, Seoane et al., 2000), Cariniana legalis (Mart.) O. Ktze. $\left(\hat{\theta}_{P}=0,09\right.$, Sebbenn et al., 2001a), Araucaria angustifolia (Bert.) Ktze. ( $\hat{\theta}_{P}=0,044$, Auler et al., 2002), Annona crassiflora Mart. ( $\hat{G}_{S T}=0,188$, Telles et al., 2003) e Eugenia dysenterica DC ( $\hat{R}_{S T}=0,269$, Zucchi et al., 2003). A causa da baixa diferenciação entre 
procedências deve-se, provavelmente, ao fluxo gênico remoto, como detectado pelo alto número médio aparente de migrantes por geração $(\hat{N} m=7,7)$.

Contudo, embora a divergência genética entre as procedências seja baixa, as estimativas das distâncias genéticas entre pares procedências (Tabela 11) e seu respectivo dendrograma (Figura 4) sugerem que, em geral, as procedências localizadas espacialmente próximas têm menor distância genética do que procedências localizadas espacialmente distantes, de forma que o fluxo gênico deva ter ocorrido mais intensivamente entre as procedências próximas. No entanto, o teste de Mantel, correlacionando a matriz de distância genética de Nei (1978) e o logaritmo natural da distancia geográfica entre procedências não suportou esta hipótese $(\hat{r}=0,198$, $P=0,159)$, de forma que não é possível atribuir a distância genética detectada entre procedências ao isolamento por distância entre as populações de origem das procedências. 


\section{VARIAÇÃO GENÉTICA ENTRE E DENTRO DE PROCEDÊNCIAS DE Mimosa scabrella BENTHAN POR CARACTERES QUANTITATIVOS E DADOS DE ISOENZIMAS - GENETIC VARIATION AMONG AND WITHIN POPULATIONS OF Mimosa scabrella BENTHAN FOR QUATITATIVE TRAIS AND ISOZYME DATAS}

\section{Resumo}

Para analisar a variação quantitativa e isoenzimática entre dez a 20 progênies de nove procedências de Mimosa scabrella (bracatinga), uma espécie arbórea tropical de ampla distribuição no sudeste e sul do Brasil, foi usada a estatística $F$. Sete locos isoenzimáticos polimórficos foram usados para testar a hipótese nula de que a seleção natural é determinante da evolução quantitativa do crescimento em altura de $M$. scabrella aos seis meses de idade. $\mathrm{O}$ crescimento em altura mostrou maior diferenciação entre procedências $\left(\hat{Q}_{S T}=0,039\right)$ do que as isoenzimas $\left(\hat{\theta}_{p}=0,018\right)$, mas menor diferenciação entre progênies dentro de procedências $\left(\hat{Q}_{p p}=0,008\right)$ do que as isoenzimas $\left(\hat{\theta}_{p / p}=0,080\right)$, sugerindo que a seleção natural foi a causa da diferenciação entre procedências e a deriva genética a causa da diferenciação entre progênies dentro de procedências. A adaptação diferencial para padrões locais e regionais de precipitação, temperatura, tipo de solo e altitude parece ser a melhor explicação para a diferente estrutura genética encontrada entre procedências para altura de plantas e locos isoenzimáticos. Por outro lado, erros de amostragem parecem ser a melhor explicação para a diferente estrutura genética detectada entre progênies dentro de procedências para altura e locos isoenzimáticos. 
Palavras-chave: Caracteres quantitativos, isoenzimas, estrutura genética, espécies arbóreas tropicais; teste de procedências e progênies. 


\section{Summary}

$F$-statistics were employed to analyse quantitative and isozyme variation among and within ten to 20 families from nine provenances of Mimosa scabrella (bracatinga), a tropical tree species with wide distribution in southwest and south Brazil. Seven polymorphic isozyme loci were used to test a null hypothesis that natural selection is determinant of quantitative evolution of $M$. scabrella height growth at six moths old.

Total height growth showed higher differentiation among provenances $\left(\hat{Q}_{S T}=0.039\right)$ than isozymes $\left(\hat{\theta}_{p}=0.018\right)$, but showed lower differentiation among families within

provenances $\left(\hat{Q}_{p p}=0.008\right)$ than isozymes $\left(\hat{\theta}_{p p}=0.080\right)$, suggesting that natural selection was the cause of differentiation among provenances and genetic drift was the cause of genetic differentiation among families within provenances. Differential adaptation to regional e local patterns of precipitation, temperature, soil type and altitude seem to be the best explanation of the different genetic structure found among provenances in total height and isozyme loci. In another hand, sampling errors seem to be the best explanation of the different genetic structure found among families within provenances in total height and isozyme loci.

Key-words: Quantitative traits, isozymes, genetic structure, tropical tree species, provenance and progeny test. 


\subsection{Introdução}

Mimosa scabrella Bentham (Leguminosae-Mimosoideae) ou bracatinga é uma espécie arbórea subtropical brasileira que ocorre naturalmente entre que as latitudes 21³0' S (Coronel Pacheco-MG) a 2940'S (RS), abrangendo os Estados de Minas Gerais (sul), Rio de Janeiro, São Paulo (leste e sul), Paraná (sul e centro sul), Santa Catarina e Rio Grande do Sul (nordeste) em altitudes preferencialmente entre $400 \mathrm{~m} \mathrm{a}$ 1.000 m (Carvalho, 1994). Sua frequiência é descontínua, tornando-se às vezes muito abundante, especialmente nas florestas de araucária semidevastadas e nas condições de vegetação secundária (Reitz et al., 1978). Suas flores são polinizadas principalmente por abelhas do tipo Apis e Trigona e tem suas sementes dispersas por autocoria. Seu crescimento é rápido até aproximadamente os seis anos de vida, após entra em fase de crescimento lento e posteriormente (10 a 12 anos) tendem a entrar em fase de declínio vital.

M. scabrella tem diversos usos, como madeira serrada e roliça, energia, celulose e papel, goma, substâncias tanantes, produção de mel, reflorestamentos ambientais etc (Carvalho, 1994). Em condições naturais, as árvores podem atingir até $20 \mathrm{~m}$ de altura e $50 \mathrm{~cm}$ de DAP (Reitz et al., 1978). Embora, M. scabrella tenha diversas aplicações, praticamente nada se conhece sobre a estrutura genética de suas populações e, segundo Carvalho (1994), as informações existentes restringem-se a um único teste de procedências.

Marcadores isoenzimáticos são, geralmente, neutros e, portanto, não são afetados

pela seleção natural, de forma que a divergência genética detectada entre populações ou procedências possa ser interpretada em termos de deriva genética e migração. Por outro lado, caracteres quantitativos como altura, DAP e volume são considerados caracteres indicativos de vigor e adaptabilidade e são fortemente afetados pela seleção natural, de forma que a diferenciação genética detectada entre populações possa ser interpretada em termos de seleção natural, deriva genética e migração ou isolamento (Yang et al., 1996; Sebbenn et al., 2001a). Quando estimativas da divergência genética entre populações são obtidas simultaneamente para caracteres quantitativos e marcadores supostamente neutros, como isoenzimas, diversas hipóteses sobre as causas das diferenças genéticas 
entre populações podem ser testadas (Yang et al., 1996; Sebbenn et al., 2001a; González-Martínez et al., 2002, Howe et al., 2003). Se as estimativas de $F_{S T}$ são iguais a $Q_{S T}$ elas sugerem que a seleção natural tenha pouco influência sobre a diferenciação entre populações para caracteres quantitativos. Se a estimativa de $F_{S T}$ é maior do que $Q_{S T}$, então a seleção estabilizadora para o mesmo fenótipo em diferentes populações está provavelmente limitando a diferenciação entre populações. Se $F_{S T}$ é menor do que $Q_{S T}$, então a seleção para alternativos fenótipos está provavelmente contribuindo para a diferenciação das populações (Howe et al., 2003). Contudo, embora a combinação dessa metodologia seja de grande valor para entender os processos causadores das diferenças genéticas entre populações, portanto, para programas de melhoramento e conservação genética de espécies, tais estudos restringem-se a poucos trabalhos com espécies arbóreas, podendo-se citar os estudos de Yang et al. (1996) com populações de Pinus contorta ssp. latifolia, Sebbenn et al. (2001a) com populações de Cariniana legalis e de González-Martínez et al. (2002) com Pinus pinaster.

O objetivo desse capítulo foi investigar a diferenças na estrutura genética de nove populações de $M$. scabrella usando o caráter quantitativo altura total e dados de sete locos isoenzimáticos polimórficos. Foi testada a hipótese nula de que a evolução quantitativa é o principal determinante da estrutura genética entre progênies dentro de procedências e entre procedências de $M$. scabrella.

\subsection{Material e Métodos}

\subsection{1 Áreas de coleta de sementes}

Esse trabalho foi desenvolvido com material genético proveniente de oito procedências naturais e uma comercial, ao longo da distribuição geográfica de $M$. scabrella. Para a escolha das localidades foram consideradas as seguintes observações: existência de procedências conhecidas e bem conservadas; e que as procedências apresentassem um número de matrizes suficiente (aproximadamente, 20 matrizes). Também foi observada a recomendação de Kemp (1976) respeitando uma distância máxima de 1 grau de latitude entre as procedências. 
Em cada município foi localizada uma procedência, exceto Ituporanga com uma procedência natural e uma comercial. A identificação das procedências e a coleta das sementes foram realizadas por técnicos da EMBRAPA/CNPF entre os anos de 1997 e 1999. A localização dos municípios está descrita na Tabela 1 e pode ser observada na Figura 1 (ambas no capítulo 3).

\subsubsection{Amostragem e teste de procedências e progênies}

O material genético testado se constitui da amostra de sementes coletadas em 10 a 20 árvores matrizes por procedência (Tabela 1), em oito procedências naturais e uma comercial de M. scabrella (Figura 1). De cada árvore foram coletadas sementes suficientes para produção de 50 mudas por progênies. As sementes foram germinadas separadas por progênie no viveiro do Departamento de Ciências Florestais da ESALQ/USP. O teste de procedências e progênies foi instalado em Maio de 2003 na Estação Experimental de Itatinga - ESALQ/USP, município de Itatinga-SP (latitudes $23^{\circ}$ 02' 01' 'S e 2302' 30', S; longitudes $48^{\circ} 38^{\prime} 34^{\prime}$ ' W e $48^{\circ} 37^{\prime} 30^{\prime}$ ' W; altitude média de $830 \mathrm{~m}$; temperatura média anual de $19,4{ }^{\circ} \mathrm{C}$ e mínima de $12,8{ }^{\circ} \mathrm{C}$; precipitação média de $1.635 \mathrm{~mm}$ e nos mês mais secos (julho) de 30 a $60 \mathrm{~mm}$ ) (Scardua, 1994). O delineamento experimental usado foi o de "Blocos de Famílias Compactas", com nove procedências, 10 a 20 progênies por procedência, seis plantas por subparcela, em cinco repetições. O espaçamento usado foi o 3,0 x 1,5 m. Também foi usada uma bordadura externa ao experimento de três linhas.

\subsubsection{Eletroforese de isoenzimas}

O protocolo de extração e revelação das isoenzimas foi desenvolvido com base em Alfenas (1998). Para a extração das isoenzimas de tecidos foliares utilizou-se o tampão de extração número um, citado em Alfenas (1998, pág. 96). Para definiç̧ão dos sistemas isoenzimáticos, foram testados três sistemas de tampão gel-eletrodo (Citrato Morfolina, Lítio Borato, e Tris Citrato), e 17 sistemas isoenzimáticos. As enzimas que apresentaram melhor atividade de resolução e permitiram a interpretação foram: Fosfogluco Isomerase (PGI-EC 5.3.1.9), Glucose-6-Fosfato Desidrogenase (G6PDHH- 
EC 1.1.1.49), Leucina Aminopeptidase (LAP-EC 3.4.11.1), Malato Desedrogenase (MDH-EC 1.1.1.37), Isocitrato Desidrogenase (IDH-EC 1.1.1.42), Menadiona Redutase (MR-EC 1.6.99.2), e a 6-Fosfogluconato Desidrogenase (6PGDH-EC 1.1.1.44). As reações isoenzimáticas foram baseadas em Alfenas (1998). Porém, com a finalidade de melhorar a resolução da enzima Fosfogluco Isomerase (PGI), optou-se pela alteração na quantidade da enzima Glucose-6-Fosfato Desidrogenase de 6,5 $\mu \mathrm{l}$ para 7,5 $\mu \mathrm{l}$. Os padrões de revelação dos sistemas isoenzimáticos, assim como, as representações esquemáticas dos fenótipos observados nos zimogramas podem ser observadas na Figura 2 e 3 (capítulo 3).

\subsubsection{Dados}

A distribuição da variabilidade genética entre e dentro das procedências e progênies foi caracterizada a partir da análise de isoenzimas e caracteres quantitativos. Seis meses após o plantio foram avaliados os caracteres quantitativos altura e sobrevivência. A altura foi medida em todas as árvores sobreviventes com o auxílio de uma trena e a sobrevivência foi obtida pela contagem direta das plantas vivas.

\subsubsection{Análise dos dados de isoenzimas}

A estrutura genética das procedências de $M$. scabrella foi caracterizada para os dados de marcadores isoenzimáticos pelas estatísticas $F$, estimadas de acordo com o método de Weir \& Cockerham (1984) e usando o programa GDA (Lewis \& Zaykin, 1999). O parâmetros estimados foram a divergência genética entre procedências $\left(\hat{\theta}_{P}\right)$ e a divergência genética entre progênies dentro de procedências $\left(\hat{\theta}_{P P}\right)$. A significância

estatística das estimativas médias entre locos de $\hat{\theta}_{P P}$ e $\hat{\theta}_{P}$ foram obtida pelo intervalo de confiança a $99 \%$ de probabilidade, calculado por reamostragem bootstrap, usando o programa GDA (Lewis \& Zaykin, 1999). Foram utilizadas 10.000 repetições sobre os locos para obter-se o intervalo de confiança. 


\subsubsection{Análise do caráter altura}

A distribuição da variabilidade genética entre e dentro de procedências para o caráter altura foi avaliada por análise de variância, usando o programa SAS (SAS, 2000). Da análise de variância foram estimados os componentes de variância, os quais permitiram a estimativa dos parâmetros genéticos. O modelo estatístico usado foi:

$$
Y_{i j k l}=m+r_{i}+s_{j}+p s_{k(j)}+p r_{j i}+p s r_{k(j / i)}+e_{(i j k l)}
$$

em que:

$\mathrm{Y}_{\mathrm{ijkl}}=$ valor do caráter medido na $l$-ésima planta, da $k$-ésima progênie, da $j$ ésima procedência, na $i$-ésima repetição;

$\mathrm{m}$ = média geral do caráter;

$\mathrm{r}_{\mathrm{i}}=$ efeito da repetição $i$;

$\mathrm{s}_{\mathrm{j}}=$ efeito da procedência $j$;

$\mathrm{ps}_{\mathrm{k}(\mathrm{j})}=$ efeito da $k$-ésima progênie dentro da $j$-ésima procedência;

$\mathrm{pr}_{\mathrm{ji}}=$ efeito da interação da $j$-ésima procedência com a $i$-ésima repetição;

$\operatorname{psr}_{\mathrm{k}(\mathrm{j} / \mathrm{i})}=$ efeito da interação da $k$-ésima progênie, com a $j$-ésima procedência, e com a $i$-ésima repetição;

$\mathrm{e}_{(\mathrm{ijkl})}=$ efeito da $l$-ésima planta, dentro da $k$-ésima progênie, da $j$-ésima procedência, na $i$-ésima repetição.

A estrutura da análise da variância para dados balanceados pode ser observada na Tabela 12 . 


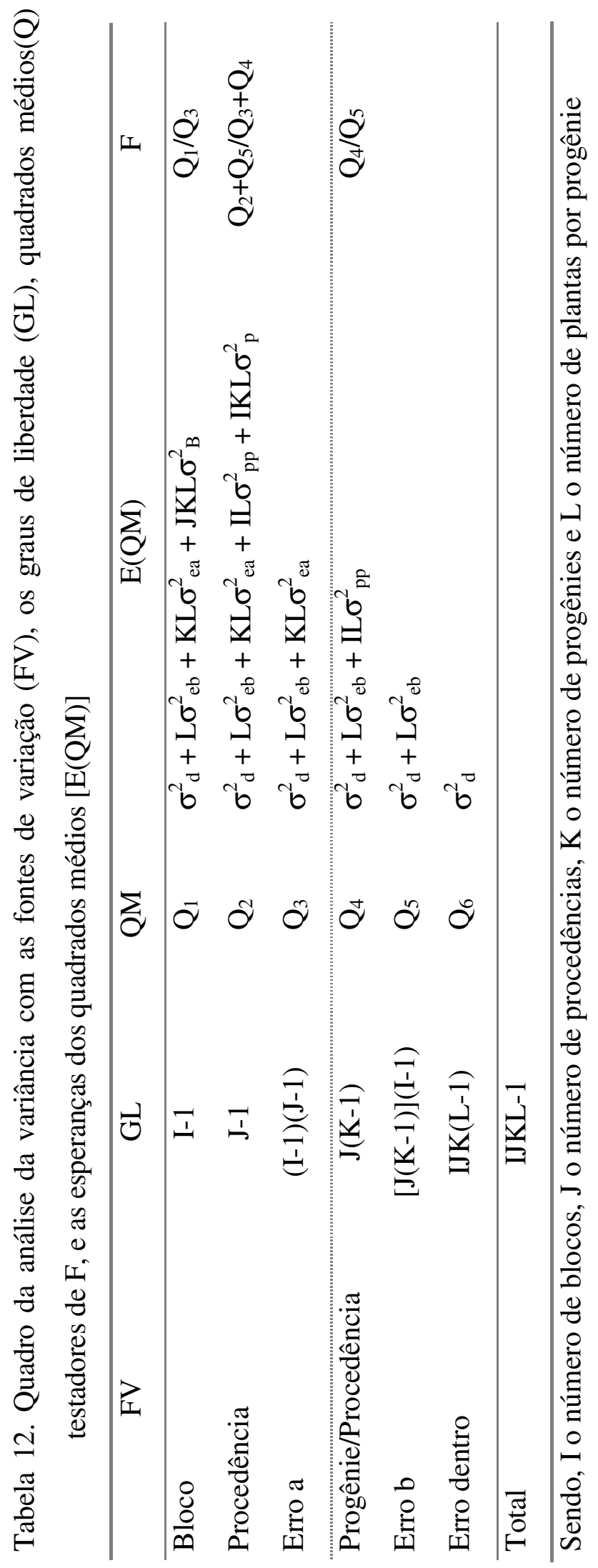


O teste $\mathrm{F}$ estimado para o efeito de procedência não foi exato, sendo necessária a decomposição dos quadrados médios. Da mesma forma, novos graus de liberdade foram obtidos usando Satterthwaite (Sebbenn, 2001) para verificar a significância estatística do teste F:

$$
\begin{aligned}
& n_{1}=\frac{\left(Q_{2}+Q_{5}\right)^{2}}{\frac{\left(Q_{2}\right)^{2}}{I-1}+\frac{\left(Q_{5}\right)^{2}}{I\left[\sum\left(K_{i}-1\right)\right](J-1)}} \\
& n_{2}=\frac{\left(Q_{3}+Q_{4}\right)^{2}}{\frac{\left(Q_{3}\right)^{2}}{(I-1)(J-1)}+\frac{\left(Q_{4}\right)^{2}}{I\left[\sum\left(K_{i}-1\right)\right]}}
\end{aligned}
$$

\section{a) Estimativa de componentes da variância}

Os componentes da variância foram obtidos pela decomposição das esperanças dos quadrados médios [E(QM)] da análise de variância:

Variância entre blocos: $\hat{\sigma}_{B}^{2}=\frac{Q_{1}-Q_{3}}{J K L}$

Variância genética entre procedências: $\hat{\sigma}_{p}^{2}=\frac{\left(Q_{2}+Q_{5}\right)}{\operatorname{IKL}\left(Q_{3}+Q_{4}\right)}$

Variância do Erro a: $\hat{\sigma}_{e a}^{2}=\frac{Q_{3}-Q_{5}}{K L}$

Variância genética entre progênies dentro de procedências: $\hat{\sigma}_{P P}^{2}=\frac{Q_{4}-Q_{5}}{I L}$

Variância do Erro b: $\hat{\sigma}_{e b}^{2}=\frac{Q_{5}-Q_{6}}{L}$

Variância fenotípica dentro de progênies: $\hat{\sigma}_{d}^{2}=Q_{6} \sigma_{\mathrm{d}}^{2}$ 


\section{b) Estimativa de parâmetros genéticos}

A divergência genética entre procedência e progênies foi calculada a partir de duas correções intraclasses:

$$
\begin{gathered}
\hat{Q}_{P}=\frac{\hat{\sigma}_{p}^{2}}{\hat{\sigma}_{d}^{2}+\hat{\sigma}_{p p}^{2}+\hat{\sigma}_{p}^{2}} \\
\hat{Q}_{p p}=\frac{\hat{\sigma}_{p p}^{2}}{\hat{\sigma}_{d}^{2}+\hat{\sigma}_{p p}^{2}+\hat{\sigma}_{p}^{2}}
\end{gathered}
$$

A diferença entre as médias de altura das procedências foi analisada pelo intervalo de confiança (IC) a $95 \%$ de probabilidade.

$$
\mathrm{IC}_{95 \%}=\underline{t} \mathrm{EP}
$$

Sendo $t$ o valor tabela do $t$ de Student, 1,96. EP $(=\sigma / \sqrt{n})$ é o erro padrão da média de altura das procedências, $\sigma$ é o desvio padrão; $n$ é o número de indivíduos mensurados.

\subsection{Resultados}

\subsubsection{Sobrevivência}

A sobrevivência média das procedências foi alta no experimento $(97,1 \%)$, variando de 93,52\% (procedência Piraí do Sul-PR) a 98,48\% (procedência Turvo-PR). Observando o intervalo de confiança da média a 95\% de probabilidade (Tabela 13), verifica-se que as diferenças entre procedências na sobrevivência são estatisticamente significativas. 
Tabela 13. Tamanho da amostra (n), taxa de sobrevivência (\%) e crescimento médio em altura aos seis meses, com seus respectivos intervalos de confiança, para as procedências de $M$. scabrella. (IC a $95 \%$ de probabilidade)

\begin{tabular}{lccc}
\hline \multicolumn{1}{c}{ Procedência } & $n$ & Sobrevivência (\%) & Altura (m) \\
\hline Itararé - SP & 390 & $97,05 \pm 0,14$ & $0,84 \pm 0,02$ \\
Piraí do Sul - PR & 202 & $93,52 \pm 0,14$ & $0,79 \pm 0,04$ \\
Mandirituba - PR & 505 & $97,87 \pm 0,14$ & $0,81 \pm 0,02$ \\
Lapa - PR & 564 & $95,92 \pm 0,14$ & $0,81 \pm 0,02$ \\
Honório Serpa - PR & 508 & $97,32 \pm 0,14$ & $0,84 \pm 0,02$ \\
Turvo - PR & 455 & $98,48 \pm 0,14$ & $0,85 \pm 0,02$ \\
Caçador - SC & 308 & $96,85 \pm 0,14$ & $0,79 \pm 0,03$ \\
Ituporanga - SC (nativa) & 289 & $98,30 \pm 0,14$ & $0,96 \pm 0,03$ \\
Ituporanga - SC (comercial) & 426 & $97,26 \pm 0,14$ & $0,84 \pm 0,03$ \\
\hline
\end{tabular}

\subsubsection{Crescimento em altura}

O crescimento médio em altura variou entre as procedências, 0,079 a 0,96 (Tabela 13). O teste de médias, baseado no intervalo de confiança do erro da média a 95\% de probabilidade, detectou diferenças entre procedências. A procedência Ituporanga (SC - nativa) apresentou a maior altura média $(0,96 \mathrm{~m})$, sendo o seu crescimento estatisticamente superior às demais. As procedências Piraí do Sul - PR e Caçador - SC apresentaram o menor crescimento $(0,79 \mathrm{~m})$ e não diferiram estatisticamente entre si e das procedências Itararé - SP (0,84 m), Mandirituba - PR (0,81 m), Lapa - PR (0,81 m), Honório Serpa - PR (0,84 m) e Ituporanga - SC (comercial) (0,84 m).

\subsubsection{Análise de variância}

O teste $F$ da análise de variância detectou diferenças significativas a $5 \%$ de probabilidade entre blocos, indicando que o delineamento experimental baseado em blocos, para o controle da variação ambiental, foi eficiente. $\mathrm{O}$ teste $F$ da análise de variância revelou diferenças significativas a $5 \%$ de probabilidade entre procedências 
para o caráter altura de plantas (Tabela 14). Entre progênies dentro de procedências não foram detectadas diferenças significativas.

Tabela 14. Análise da variância para o caráter altura aos seis meses para as nove procedências de M. scabrella. São apresentados: as fontes de variação (FV), os graus de liberdade (GL), os quadrados médios (QM) e o teste de significância $(\mathrm{F})$

\begin{tabular}{lrrr}
\hline \multicolumn{1}{c}{ FV } & GL & QM & F \\
\hline Bloco & 4 & 0,9359 & $5,92^{*}$ \\
Procedência & 8 & 0,7726 & $4,75^{*}$ \\
Progênie/Procedência & 130 & 0,1633 & 1,03 \\
Erro b & 482 & 0,1591 & \\
Erro Dentro & 3022 & 0,0453 & \\
\hline Total & 3646 & & \\
\hline
\end{tabular}

CV: 25,44\%; Média: 0,84 m. * P>0,05.

\subsubsection{Variação genética entre e dentro de procedências}

A divergência genética entre procedências $\left(\hat{Q}_{p}\right)$ para o caráter altura foi de 0,039 e a divergência genética entre progênies dentro de procedências $\left(\hat{Q}_{p p}\right)$ foi de 0,008 , de forma $95,3 \%\left(1-\hat{Q}_{p}-\hat{Q}_{p p}\right)$ da variação total, encontrava-se distribuída entre plantas dentro de progênies (Tabela 15). Para as isoenzimas, a divergência genética média entre procedências, para a média dos locos, acomodou $1,8 \%$ da diversidade total, com variação entre locos de $-0,001$ a 0,046. Entre progênies, para a média dos locos, foi detectados 8,0\% de divergência genética, com variação entre locos de 0,018 (Lap) a 0,114 (Pgi-2). Avaliando os limites do intervalo de confiança do erro a $99 \%$ de probabilidade, conclui-se que essas diferenças são estatisticamente significativas. 
Tabela 15. Estimativas das estatísticas $F$, para dados de isoenzimas com base no modelo de Weir \& Cockerham (1984) e para o caráter quantitativo altura de plantas entre nove procedências de $M$. scabrella. ( $\hat{\theta}_{p}$ é a divergência genética entre procedências; $\hat{\theta}_{p p}$ divergência genética entre progênies dentro de procedências; $\hat{Q}_{P}$ é a divergência genética entre procedências; $\hat{Q}_{p p}$ divergência genética entre progênies dentro de procedências)

\begin{tabular}{lccccc}
\hline Loco & $\hat{\theta}_{p p}$ & $\hat{\theta}_{p}$ & Caráter & $\hat{Q}_{p p}$ & $\hat{Q}_{P}$ \\
\hline Mr-1 & 0,047 & 0,017 & & \\
G6pd & 0,089 & 0,046 & & \\
Pgi-2 & 0,114 & 0,006 & & \\
Mdh-4 & 0,131 & 0,026 & & \\
Lap & 0,018 & $-0,001$ & & \\
6pgdh-2 & 0,055 & 0,018 & & & \\
Idh-1 & 0,111 & 0,010 & Altura & 0,008 & 0,039 \\
& & & & \\
Média & 0,080 & 0,018 & & & \\
IC-superior & 0,116 & 0,033 & & & \\
IC-inferior & 0,042 & 0,006 & & & \\
\hline
\end{tabular}

\subsection{Discussões}

\subsubsection{Caracteres quantitativos}

Características adaptativas, ou seja, que sofrem seleção natural, são apropriadas aos estudos de estrutura genética de procedências por permitirem a detecção da competição intra-específica. Dessa forma, a avaliação da variabilidade genética para os caracteres altura e sobrevivência tornou-se pertinentes por informar de como está distribuída a variabilidade entre e dentro de procedências, conseqüentemente, permitindo o delineamento de estratégias para a seleção de procedências para o melhoramento e conservação genética. 


\section{a) Sobrevivência}

A sobrevivência média das procedências foi alta no experimento $(97,1 \%)$, embora tenham sido detectadas diferenças significativas entre procedências. Isso indica que a origem geográfica das sementes possa estar influenciando a adaptação das procedências no local de experimentação e, que a escolha da origem adequada possa ter influência sobre a adaptação e produtividade local. Contudo, embora, existam diferenças significativas entre procedências para sobrevivência de planta, todas apresentaram altas taxas, o que por sua vez, sugere que a espécie, aparentemente, adapta-se bem as condições edafoclimáticas da região de experimentação (Estação Experimental de Itatinga). Ainda, os valores observados de sobrevivência são condizentes com os resultados já obtidos para a $M$. scabrella. Carvalho (1981a) encontrou valores entre 84 e 99,2\% para a sobrevivência da espécie, variando conforme o local de experimentação.

A sobrevivência de plantas é, provavelmente, um caráter que está sob forte controle genético em espécies arbóreas. A alta sobrevivência pode ser vista como um indicativo de que no processo de reprodução, pouca endogamia foi gerada (autofecundação e cruzamentos entre parentes) ou, que esta foi eliminada pela seleção natural entre a fase de formação do zigoto e a fase atual (plântulas).

\section{b) Crescimento em altura}

O crescimento médio em altura variou entre as procedências, 0,79 a 0,96 (Tabela 13). O teste de médias, baseado no intervalo de confiança do erro da média a $95 \%$ de probabilidade, detectou diferenças entre procedências. A procedência Ituporanga (SC nativa) apresentou a maior altura média $(0,96 \mathrm{~m})$, sendo o seu crescimento estatisticamente superior às demais. As procedências Piraí do Sul - PR e Caçador - SC apresentaram o menor crescimento $(0,79 \mathrm{~m})$ e não diferiram estatisticamente entre si e das procedências Itararé - SP (0,84 m), Mandirituba - PR (0,81 m), Lapa - PR (0,81 m), Honório Serpa - PR (0,84 m) e Ituporanga - SC (comercial) (0,84 m). Embora, esses resultados sejam preliminares, eles indicam que a procedência Ituporanga (SC - nativa) é a mais adequada para o reflorestamento na região de Itatinga. Seu crescimento $(0,96 \mathrm{~m})$ foi $18 \%$ superior ao observado nas duas procedências de pior performance $(0,79 \mathrm{~m}$; Piraí 
do Sul - PR e Caçador - SC). Comparando com a procedência Ituporanga comercial verifica-se que a Ituporanga nativa cresceu $12,5 \%$ a mais. A causa da diferença entre a procedência Ituporanga nativa e comercial é provavelmente o processo de domesticação a partir de uma base genética restrita, como detectado pelo índice de fixação (capítulo 4). Resultados mais consistentes poderão ser obtidos em avaliações subseqüentes, quando as árvores estiverem pelo menos com idade correspondente a um terço da idade de rotação da espécie, ou seja, aproximadamente aos dois anos.

Os resultados aqui observados divergem dos encontrados para altura de $M$. scabrella aos quatro anos de idade por Dias (1988). Embora o autor não tenha encontrado tendências coerentes entre altura e latitude, os indivíduos mais altos eram representantes das procedências próximas do local de plantio. O oposto foi encontrado nesse estudo onde a procedência que se destacou positivamente é a que apresenta localização mais meridional. A diferença nos resultados pode ser atribuída a jovialidade do plantio em Itatinga (SP). Como possivelmente a altura esteja sobre controle de um grande número de genes que são influenciados pelo ambiente, sua expressão pode ser alterada, em maior ou menor grau, com o desenvolvimento dos indivíduos. Portanto, os resultados são preliminares e é necessário acompanhar o experimento até que as médias de crescimento se estabilizem.

\section{c) Análise de variância}

O teste $F$ da análise de variância revelou diferenças significativas a $5 \%$ de probabilidade entre procedências para o caráter altura de plantas (Tabela 14), indicando que existem diferenças significativas entre as médias de crescimento em altura de pelo menos duas procedências e a possibilidade de obter-se ganhos genéticos pela seleção da(s) procedência(s) de maior crescimento (por exemplo, Ituporanga nativa). Entre progênies dentro de procedências não foram detectadas diferenças significativas, o que sugere, até a presente data (seis meses de experimentação), demonstrando baixa possibilidades de capitalizar-se ganhos genéticos pela seleção das melhores progênies dentro das procedências é fraca. 


\subsubsection{Variação genética entre e dentro de procedências por caracteres quantitativos}

Estudou-se a distribuição da diversidade genética entre e dentro de procedências de M. scabrella para o caráter altura, com base em correlações intraclasses. A divergência genética detectada entre procedências $\left(\hat{Q}_{p}\right)$ para o caráter quantitativo altura total de plantas foi baixa $(0,039)$, indicando que a maior parte da variação total encontrase distribuída dentro de procedências (entre progênies e entre plantas dentro de procedências). Esse padrão de estrutura genética, com baixa variação entre procedências e alta dentro de procedências tem sido reportada para a grande maioria das espécies arbóreas. Praticamente todos os estudos de estrutura genética de populações baseadas em caracteres quantitativos têm detectado que a maior parte da diversidade genética encontra-se dentro das populações ou procedência, podendo-se citar como exemplo os estudos Yang et al. (1996) com Pinus contorta ssp. Latifólia; Siqueira et al. (2000) com Balfourodendron riedelianum (Engler) Engler; Sebbenn et al. (2001a; 2002b; 2003a e b) com Cariniana legalis (Mart.) O. Ktze, Gallesia gorarema Vell. Moq., e Araucaria angustifolia (Mart.) O Ktze; Ettori et al. (2002) com Pinus oocarpa Schiede; e Baleroni et al. (2003) com Myracrodruon urundeuva Fr. All, entre outros. A maior variação dentro de procedências ocorre devido a uma combinação do sistema de reprodução, predominantemente por cruzamento em espécies arbóreas, vida longa das espécies arbóreas e eficientes mecanismos de dispersão de pólen e sementes, fazendo com que a variabilidade genética das populações seja homogeneizada e, conseqüentemente, reduzindo a diversidade entre populações. 
Tabela 16. Estimativa da divergência genética entre procedência ou populações $\left(\hat{Q}_{P}\right)$ para o caráter altura total de plantas de algumas espécies arbóreas

\begin{tabular}{lccl}
\hline Espécie & $\begin{array}{c}\text { Idade } \\
\text { (anos) }\end{array}$ & $\hat{Q}_{P}$ & \\
\hline Araucaria angustifolia & 1 & 0,288 & Sebbenn et al. (2003a) \\
& 3 & 0,086 & \\
& 5 & 0,158 & \\
Araucaria angustifolia & 18 & 0,065 & \\
Balfourodendron riedelianum & 21 & 0,062 & Sebbenn et al. (2003b) \\
& 4 & 0,013 & Siqueira et al. (2000) \\
Cariniana legalis & 9 & 0,001 & \\
Grevillea robusta & 11 & 0,000 & \\
Myracrodruon urundeuva & 17 & 0,010 & Sebbenn et al. (2001a) \\
& 11 & 0,192 & Sebbenn et al. (2003c) \\
Pinus pinaste & 13,5 & 0,152 & Baleroni et al. (2003) \\
P. contorta ssp. latifolia & 14,5 & 0,097 & \\
Pinus oocarpa & 30 & 0,790 & Gonzálsez-Martinez et al. (2002) \\
& 10 & 0,195 & Yang et al. (1996) \\
P. caribaea var. bahamensis & 18 & 0,102 & Ettori et al. (2002) \\
Média & 18 & 0,061 & \\
\hline
\end{tabular}

Em relação à magnitude da divergência genética detectada entre procedências para o caráter altura $(0,039)$, comparado a média obtida para altura de plantas para as espécies listadas na Tabela $16(0,146)$, verifica-se que as procedências de $M$. scabrella, aos seis meses de idade, expressão baixa diferenciação genética entre si. A divergência de detectada só foi superior a observada em B. riedelianum (Siqueira et al., 2000) e $C$. legalis (Sebbenn et al., 2001a). Contudo, é importante ressaltar que a divergência pode se alterar com o desenvolvimento das árvores, no sentido de aumentar ou diminuir. Em geral, de acordo com a Tabela 16, o que acontece é que a divergência diminui com o crescimento. A causa é que as arvores, igualmente como qualquer outro organismo, podem expressar diferentes genes, ou complexos gênicos, em diferentes fases de vida. Em exemplo, simples para entender esse processo é o caso da reprodução sexual, que um em grande número de organismos, ai inclui-se as espécies arbóreas, não são reprodutivos na fase inicial de desenvolvimento ou fase juvenil, tornando-se 
reprodutivos em fases mais avançadas, devido à ativação de genes responsáveis pela reprodução sexual. Assim, genes que determina a reprodução sexual estão inativos ou "desligados" na fase juvenil e tornam-se ativos em fases mais avançadas. A mesma explicação pode ser atribuída a diferente expressão da divergência genética entre procedências medida para os caracteres quantitativos, sendo que na fase de précompetição, alguns genes responsáveis, por exemplo, pelo crescimento em altura, podem não estar se expressando e vir se expressar em fases mais avançadas, ou viceverso, genes que estão se expressando na fase pré-competitiva podem ser desligados na fase de competição, aumentando ou diminuindo a quantidade de diferenciação genética entre procedências.

A variação entre progênies dentro de procedências foi também baixa ( $\left.\hat{Q}_{p p}=0,008\right)$ e menor do que a variação entre procedências $\left(\hat{Q}_{p}=0,039\right)$, o que sugere eficientes mecanismos de dispersão genética (pólen e sementes) dentro das populações de origem das procedências. Esse resultado também demonstra que a maior parte da diversidade genética das procedências de $M$. scabrella reside entre plantas dentro de progênies.

\subsubsection{Variação genética entre e dentro de procedências por dados de isoenzimas}

A análise da distribuição da diversidade genética entre e dentro de procedências por marcadores isoenzimáticos indicou que apenas 1,8\% da diversidade genética total encontra-se entre procedências e, portanto, a maior parte encontra-se dentro de procedências. O padrão de estrutura genética com maior parte da diversidade distribuída dentro das procedências ou populações é coerente com o padrão esperado em espécies que se reproduzam predominantemente por cruzamento, tem vida longa (>10 anos), alta densidade populacional e eficientes mecanismos de dispersão sementes e pólen (Hamrick, 1983), como M. scabrella. Maior diversidade genética dentro de populações, relativamente a presente entre populações tem sido observada na grande maioria dos estudos conduzidos com marcadores genéticos em espécies arbóreas tropicais, podendo citar como exemplo os estudos com Cordia alliodora (R. and P.) Oken ( $\hat{G}_{S T}=0,117$, 
Chese et al., 1995); Pterocarpus macrocarpus Kurz. ( $\hat{F}_{S T}=0,117$, Liengsiri et al., 1995); Cryptocarya moschata Nees ( $\hat{\theta}_{P}=0,123$, Moraes et al., 1999); Esenbeckia leiocarpa Engl. ( $\hat{\theta}_{P}=0,121$, Seoane et al., 2000); Cariniana legalis (Mart.) O. Ktze. ( $\hat{\theta}_{P}=0,09$, Sebbenn et al., 2001a); Araucaria angustifolia (Bert.) Ktze. $\left(\hat{\theta}_{P}=0,044\right.$, Auler et al., 2002); Annona crassiflora Mart. ( $\hat{G}_{S T}=0,188$, Telles et al., 2003); e Eugenia dysenterica DC $\left(\hat{R}_{S T}=0,269\right.$, Zucchi et al., 2003). A causa da baixa diferenciação entre procedências deve-se, provavelmente, ao fluxo gênico remoto.

\subsubsection{Comprando a estrutura genética detectada por dados quantitativos com dados de isoenzimas}

Marcadores isoenzimáticos são, geralmente, neutros e, portanto, não são afetados pela seleção natural, de forma que a divergência genética detectada entre populações ou procedências possa ser interpretada em termos de deriva genética e migração. Por outro lado, caracteres quantitativos como altura, DAP e volume são considerados caracteres indicativos de vigor e adaptabilidade e são fortemente afetados pela seleção natural, de forma que a diferenciação genética entre populações possa ser interpretada em termos de seleção natural, deriva genética e migração (Sebbenn et al., 2001a). Assim, quando estimativas da divergência genética entre populações ou procedências são obtidas simultaneamente para caracteres quantitativos e marcadores supostamente neutros, como isoenzimas, diversas hipóteses sobre as causas das diferenças genéticas entre populações podem ser testadas. Se as estimativas de $F_{S T}$ são iguais a $Q_{S T}$ elas sugerem que a seleção natural tenha pouco influência sobre a diferenciação entre populações para caracteres quantitativos. Se a estimativa de $F_{S T}$ é maior do que $Q_{S T}$, então a seleção estabilizadora para o mesmo fenótipo em diferentes populações está provavelmente limitando a diferenciação entre populações. Se $F_{S T}$ é menor do que $Q_{S T}$, então a seleção para alternativos fenótipos está provavelmente contribuindo para a diferenciação das

populações (Howe et al., 2003). Assim, comparando as estimativas de $\hat{Q}_{p}(0,039)$ obtidas para altura aos seis meses de idade com as obtidas para a média dos sete locos 
isoenzimáticos $(0,018)$ avaliados nas procedências de $M$. scabrella (Tabela 15), pode-se supor que a diferenciação entre procedências para o caráter altura esteja sob o efeito da seleção natural. Por outro lado, comparando a divergência genética entre progênies, medida para altura de plantas $\left(\hat{Q}_{p p}=0,008\right)$ com o medida para as isoenzimas $\left(\hat{\theta}_{p p}=0,080\right)$, verifica-se que a diferença quantitativa entre progênies está sob o efeito da deriva genética aleatória.

Contudo, é importante ressaltar que esse quadro pode ser alterado com o desenvolvimento das árvores. A divergência genética medida entre procedências com base em dados de isoenzimas não será alterada, mas a divergência genética entre procedências ou entre progênies dentro de procedências pode alterar-se devido a mudanças na pressão de seleção em diferentes fases de vida das plantas, de forma que tais divergências podem aumentar ou diminuir, conforme for à pressão de seleção sobre o caráter. Em outros termos, um caráter pode mostrar diferenças genéticas, por exemplo, entre procedências devido à seleção natural, em uma fase de vida das plantas e por deriva genética em outra fase, simplesmente porque a pressão de seleção sobre o caráter mudou.

Os resultados observados para altura total de plantas em $M$. scabrella podem ser comparados com outros realizados com espécies arbóreas. Yang et al. (1996) estudando a estrutura genética de cinco populações Pinus contorta ssp. latifolia por caracteres quantitativos e por locos isoenzimáticos detectaram maior diferenciação entre populações para os caracteres quantitativos densidade específica da madeira $(0,133)$, DAP $(0,166)$, altura $(0,195)$ e comprimento dos galhos $(0,161)$ relativamente as isoenzimas $(0,019)$, indicando que a seleção é a principal causa da diferenciação quantitativa entre as populações. Por outro lado, os autores observaram ausência de diferenças estatística entre a medida de divergência genética entre procedências para os caracteres ângulo dos ramos $(0,006)$ e diâmetro dos ramos $(0,057)$ e as isoenzimas, concluindo que a causa da divergência quantitativa entre as populações ocorreu por deriva genética. Sebbenn et al. (2001a) estudou a diferenciação entre três populações de C. legalis usando caracteres quantitativos e isoenzimas e observou que os caracteres 
quantitativos forma e volume tinham maior valor para o $\hat{Q}_{p}(0,047$ e 0,127 , respectivamente) em relação as isoenzimas $(0,009)$, sugerindo a seleção como a cauda da diferenciação genética entre as populações. Para os caracteres DAP e altura os autores observaram o oposto $\left(\hat{Q}_{p}=0,001\right.$ para ambos caracteres $)$, ou seja, que a diferenciação quantitativa entre as populações foi causada por deriva genética. González-Martínez et al. (2002) por sua vez, compararam a estrutura genética por caracteres quantitativos e isoenzimas em 19 populações de Pinus pinaster Ait., e observaram que todos os caracteres quantitativos apresentaram maior diferenciação genética entre procedências (variação entre caracteres de 0,732 a 0,973) do que a média dos locos isoenzimáticos $(0,048)$ e, assim, atribuíram a diferenciação quantitativa entre procedências aos efeitos da seleção natural.

Em suma, existem diferenças genéticas significativas entre procedências de $M$. scabrella tanto para o caráter quantitativo altura total de plantas como para os sete locos isoenzimáticos, mas a diferenciação entre procedências é maior para altura de plantas do que para a média dos locos isoenzimáticos, de forma que se atribui a diferenciação para altura entre procedências aos efeitos da seleção natural, favorecendo as árvores de procedências de maior crescimento. Assim confirmou-se a hipótese de que a evolução quantitativa é o principal determinante da diferenciação entre procedências de $M$. scabrella. 


\section{ESTIMATIVAS DE PARAMETROS GENÉTICOS EM POPULAÇÕES DE Mimosa scabrella BENTHAM USANDO OS MODELOS ALEATÓRIO E MISTO DE REPRODUÇÃO - ESTIMATES OF GENETIC PARAMETERS IN Mimosa scabrella BENTHAM POPULATIONS USING RANDOM AND MIXED MATING SYSTEM MODELS}

\section{Resumo}

Herdabilidades e ganhos esperados na seleção foram estimados para nove procedências de Mimosa scabrella Benth., usando os modelos aleatório e misto de reprodução para cálculo do coeficiente de parentesco médio entre plantas dentro de progênies. O teste de procedência e progênie foi instalado na Estação Experimental de Itatinga (ESALQ/USP), a partir de nove procedências, 10 a 20 progênies por procedência, seis plantas por parcela e cinco repetições. As procedências foram amostradas ao longo da distribuição geográfica natural da espécie (sudeste e sul do Brasil). O caráter altura foi mensurado seis meses após o plantio no campo. Adicionalmente, uma amostra de progênies de todas as procedências foi analisada a partir da técnica de eletroforese de isoenzimas, visando estimar parâmetros do sistema de reprodução. $M$. scabrella possui o sistema misto de reprodução, com predomínio de cruzamentos. O coeficiente médio de parentesco $\left(\hat{r}_{x y}\right)$ dentro procedências, estimado de parâmetros do sistema de reprodução foi de 0,392 , portanto, foi $36 \%$ superior ao esperado em progênies de meios-irmãos $(0,25)$. As estimativas médias da variância genética aditiva, herdabilidade dentro de progênies e ganhos esperados na seleção entre e dentro de progênies, calculadas com base no modelo aleatório de reprodução, que assume que progênies de polinização aberta são meios-irmãos, foram superestimadas, 
em $36 \%, 48 \%$ e $41 \%$, respectivamente, quando comparadas com as estimativas obtidas com base no modelo misto de reprodução, que assume mistura de diferentes tipos de progênies como meios-irmãos, irmãos-completos e irmãos de autofecundação).

Palavras-chave: Coeficiente de coancestria, parentesco, endogamia, sistema de reprodução, melhoramento florestal, isoenzimas. 


\section{Summary}

Heritability coefficients and expected gains selection were estimates for nine Mimosa scabrella Bentham provenances, using a random and mixed mating system models to calculate the average coancestry coefficient among plants within families. The provenance and progeny test was implanted in the Itatinga Experimental Station (ESALQ/USP), from nine provenances, 10 to 20 families per provenance, six plants per plot and five replications. The provenance were sampled form all natural geographic distribution of species (southwest and south of Brazil). The trait measured was height at six years old. Additionally, a sample of progeny of all provenances was evaluated by isozymes electrophoresis analysis, to estimate the mating system parameters. $M$. scabrella has a mixed mating system with predominance of outcrossing. The average relatedness coefficient $\left(\hat{r}_{x y}\right)$ within provenances, estimate of mating system parameters was 0.392 , therefore, was $36 \%$ highest to expected in half-sibs progenies $(0.25)$. The average estimate of additive genetic variance, within progeny heritability and among and within progeny expected gains selection, calculated with base on random mating model, that assume open-pollinated progenies are half-sibs, were super-estimate in $36 \%, 48 \%$ and $41 \%$, respectively, where compared with estimates with base in mixed mating system model, that assume mixtures of different kind of progenies, as half-sibs, full-sibs and self-sibs).

Keywords: Coancestry coefficient, relatedness, inbreeding, mating system, forest breeding, isozymes. 


\subsection{Introdução}

A Mimosa scabrella Bentham (bracatinga) é uma espécie arbórea nativa de grande importância socioeconômica para a região sul do Brasil. A espécie vem sendo cultivada nos arredores de Curitiba - PR desde o início do século XX, consistindo no sistema agroflorestal mais antigo do país. A técnica é praticada por pequenos e médios proprietários pouco capitalizados e, principalmente, em terrenos íngremes (Carpanezzi, 1997).

Muitas das características silviculturais de $M$. scabrella são conhecidas. Entretanto, faltam estudos sobre a genética da espécie, tanto em termos de melhoramento como de conservação. A região brasileira de ocorrência natural de $M$. scabrella está entre as mais degradas e fragmentadas do Brasil, devido à intensa urbanização, industrialização e desenvolvimento agropecuário. O risco de perda de variabilidade genética é iminente, tendo em vista que as populações remanescentes encontram-se, em sua maioria isolada, em fragmentos florestais.

As espécies arbóreas, em geral, têm baixa produtividade em populações naturais. O uso de técnicas de melhoramento genético pode aumentar consideravelmente a produtividade (Clement, 2001). O melhoramento genético de espécies arbóreas nativas é similar ao de espécies exóticas, porém, merece alguns cuidados especiais na coleta de sementes e na instalação de experimentos. Nos últimos anos, com o desenvolvimento de técnicas de análises moleculares, muitos trabalhos têm caracterizado a variabilidade das espécies arbóreas, assim como o seu sistema de reprodução. Tais estudos são fundamentais para a efetiva conservação e o melhoramento genético de uma espécie, visto que são estas informações que permitiram o delineamento de estratégias ótimas para esses fins (Brown, 1978; Resende et al., 1995).

Um fator importante no melhoramento genético de espécies florestais tropicais é que essas apresentam, em sua maioria, sistema misto de reprodução, combinado a reprodução predominantemente por cruzamentos com parcial autofecundação (Bawa, 1974). O sistema de reprodução determina como as informações genéticas são transferidas de uma geração para a outra (Wright, 1921), podendo influenciar fortemente 
o potencial de recombinação da população e a estrutura genética da população (Allard, 1971).

Os trabalhos de melhoramento genético têm evoluído muito, mas geralmente na suposição de endogamia total (autógamas), ou de panmixia (alógamas) (Vencovsky et al., 2001). As populações de sistema de reprodução misto diferem das que apresentam autogamia ou alogamia completa, por possuir uma mistura de indivíduos com diferentes graus de endogamia e parentesco (Vencovsky et al., 2001).

Em programas de melhoramento genético, baseado em progênies de polinização aberta, em geral tem-se assumido que a coancestria entre plantas dentro de progênies é igual à esperada em progênies de meios-irmãos $(0,125)$, de forma que a variância genética aditiva entre plantas dentro de progênies estima $1 / 4$ da variância genética aditiva (Sebbenn et al., 2002a). Contudo, esse modelo, conhecido como modelo aleatório de reprodução, tem sido questionado (Namkoong, 1966; Squillace, 1974; Surles et al., 1990; Sebbenn, 2002), devido a populações naturais, muitas vezes, apresentarem estrutura genética espacial, endogamia e a reprodução não ser perfeitamente aleatória, combinando cruzamentos aleatórios, biparentais, endogâmicos e autofecundações (Sebbenn, 2003b). Por isso, em programas de melhoramento genético baseados em progênies de polinização aberta, alguns pesquisadores tem advogado o uso do coeficiente de parentesco de 0,333 (Bridgwater, 1992), ao invés de 0,25, afim de corrigir os desvios da pressuposição do modelo aleatório de reprodução.

Diversos modelos têm sido propostos para a estimativa de parâmetros genéticos em caracteres quantitativos de espécie de sistema misto de reprodução como, por exemplo, os modelos de Ghai (1982) e Cockerham \& Weir (1984). O modelo de Ghai (1982), apesar de simples, tinha a desvantagem de não considerar o desequilíbrio de ligação entre locos e fazer com que a variância genética aditiva e variância de dominância variassem com a taxa de autofecundação (Cockerham \& Weir, 1984). Por sua vez, o modelo de Cockerham \& Weir (1984) é baseado no modelo de equilíbrio de endogamia de Wright, e assume que as progênies de polinização aberta foram originadas por misturas de cruzamentos aleatórios e autofecundações, de forma que são constituem misturas de meios-irmãos e irmãos de autofecundação. Com base no modelo de 
Cockerham \& Weir (1984) a variância genética aditiva $\left(\sigma_{A}^{2}\right)$ podia ser estimada diretamente do coeficiente de endogamia $(F)$ por, $\sigma_{A}^{2}=4 \sigma_{p}^{2} /(1+F)$, sendo $\sigma_{p}^{2}$ a variância genética entre progênies. Contudo, o modelo de Cockerham \& Weir (1984) não é o mais apropriado para espécies arbóreas, devido a muitas populações naturais apresentaram estrutura genética espacial e endogamia e reproduzir-se por misturas de cruzamentos aleatórios, biparentais, endogâmicos e autofecundações (Sebbenn, 2002). Ritland (1989) apresentou um novo modelo para a estimativa da variância genética aditiva em caracteres quantitativos de espécies de sistema misto de reprodução, baseado na estimativa do coeficiente de parentesco entre plantas dentro de progênies $\left(r_{x y}\right)$ a partir de parâmetros do sistema de reprodução como, taxa de cruzamento $(t)$, taxa de autofecundação $(s)$, coeficiente de endogamia na geração parental $(F)$, correlação de autofecundação $\left(r_{s}\right)$ e correlação de paternidade $\left(r_{p}\right)$, que pode ser descrido como, $\sigma_{A}^{2}=\sigma_{p}^{2} / 0,25(1+F)\left[4 s+\left(t^{2}+s t r_{s}\right)\left(1+r_{p}\right)\right]$.

Esse é o modelo mais completo atualmente, embora ele não acomode a presença de cruzamentos entre parentes e foi utilizado por Sebbenn et al. (2002a) para estimar parâmetros genéticos em caracteres quantitativos de Cariniana legalis (Mart.) O. Ktze.

O objetivo desse capítulo é estimar e comparar parâmetros genéticos para o caráter altura de plantas em populações de M. scabrella, calculados usando os modelos aleatório e misto de reprodução. Os parâmetros do sistema de reprodução para cada população foram previamente estimados de dados de sete locos isoenzimáticos. Os parâmetros genéticos estimados foram: a variância genética aditiva, os coeficientes de herdabilidade em nível de plantas individuais e entre plantas dentro de progênies e os ganhos esperados na seleção. 


\subsection{Material e Métodos}

\subsubsection{Coleta das amostras}

Esse trabalho foi desenvolvido com material genético proveniente de oito procedências naturais e uma comercial, ao longo da distribuição geográfica de $M$. scabrella. Para a escolha das localidades foram consideradas as seguintes observações: existência de procedências conhecidas e bem conservadas; e que as procedências apresentassem um número de matrizes suficiente (aproximadamente, 20 matrizes). Também foi observada a recomendação de Kemp (1976), respeitando uma distância máxima de 1 grau de latitude entre as procedências. Em cada município foi localizada uma procedência, exceto Ituporanga com uma procedência natural e uma comercial. A identificação das procedências e a coleta das sementes foram realizadas por técnicos da EMBRAPA/CNPF entre os anos de 1997 e 1999. A localização dos municípios está descrita na Tabela 1 e demonstrada na Figura 1 (capítulo 3). O número de progênies amostradas por procedência para estimar os parâmetros genéticos $(m)$, e utilizadas na análise isoenzimática podem ser observada na Tabela 17.

Tabela 17. Número de progênies amostradas por procedência para utilização no teste de procedências e progênies $(m)$, e na análise isoenzimática $(n i)$.

\begin{tabular}{lll}
\hline \multicolumn{1}{c}{ Município - Estado } & $m$ & $n i$ \\
\hline Itararé - SP & 20 & 10 \\
Piraí do Sul - PR & 19 & 07 \\
Mandirituba - PR & 20 & 12 \\
Lapa - PR & 20 & 09 \\
Honório Serpa - PR & 20 & 11 \\
Turvo - PR & 20 & 12 \\
Caçador - SC & 20 & 09 \\
Ituporanga - SC - pop. nativa & 10 & 10 \\
Ituporanga - SC - pop. comercial & 19 & 09 \\
\hline
\end{tabular}


Em cada local (procedência) foram coletadas sementes de 10 a 20 árvores matrizes. De cada árvore foram coletadas sementes suficientes para produção de 50 mudas por progênies. As sementes foram germinadas separadas por progênie no viveiro do Departamento de Ciências Florestais da ESALQ/USP. O teste de procedências e progênies foi instalado em Maio de 2003 na Estação Experimental de Itatinga ESALQ/USP, município de Itatinga-SP (latitudes $23^{\circ} 02^{\prime} 01^{\prime}$ ' S e $23^{\circ} 02^{\prime} 30^{\prime}$ ' S; longitudes $48^{\circ} 38^{\prime} 34^{\prime}$ ' W e $48^{\circ} 37^{\prime} 30^{\prime}$ ' W; altitude média de $830 \mathrm{~m}$; temperatura média anual de $19,4{ }^{\circ} \mathrm{C}$ e mínima de $12,8{ }^{\circ} \mathrm{C}$; precipitação média de $1.635 \mathrm{~mm}$ e nos mês mais secos (julho) de 30 a 60 mm) (Scardua, 1994). O delineamento experimental usado foi o de "Blocos de Famílias Compactas" (Wright, 1978), com nove procedências representando o efeito de parcela, 10 a 20 progênies por procedência, representando o efeito de subparcela, seis plantas por subparcela, em cinco repetições. O espaçamento adotado foi o 3,0 x 1,5 m. O experimento foi rodeado por uma bordadura externa de três linhas.

\subsubsection{Dados}

O caráter quantitativo avaliado foi a altura total de plantas, aos seis meses após o plantio. Adicionalmente, para estimar os parâmetros do sistema de reprodução de $M$. scabrella e calcular o coeficiente de parentesco entre plantas dentro de progênies, uma amostra parcial de progênies e plantas por progênie foi tomada do ensaio (Tabela 17). Com o intuito de avaliar os efeitos do crescimento das árvores nos níveis de diversidade genética isoenzimática e índice de fixação, foram coletadas amostras, em cada procedência, das 10 plantas com maior altura, das 10 com menor altura e de 30 plantas aleatórias no restante da procedência (entre as 10 menores e as 10 maiores). Aproximadamente 50 indivíduos foram amostrados por procedência, totalizando 450 plantas no total do ensaio. As folhas foram coletadas, embaladas em sacos plásticos devidamente identificados com o número da árvore de origem e transportadas para o Laboratório de Reprodução e Genética de Espécies Arbóreas (LARGEA/ESALQ/USP) e submetidas imediatamente as análises de eletroforese de isoenzimas. 


\subsubsection{Eletroforese de isoenzimas}

O protocolo de extração e revelação das isoenzimas foi desenvolvido com base em Alfenas (1998). Para a extração das isoenzimas de tecidos foliares utilizou-se o tampão de extração número um, citado em Alfenas (1998, pág. 96). Para definição dos sistemas isoenzimáticos, foram testados três sistemas de tampão gel-eletrodo (Citrato Morfolina, Lítio Borato, e Tris Citrato), e 17 sistemas isoenzimáticos. As enzimas que apresentaram melhor atividade de resolução e permitiram a interpretação foram: Fosfogluco Isomerase (PGI-EC 5.3.1.9), Glucose-6-Fosfato Desidrogenase (G6PDHHEC 1.1.1.49), Leucina Aminopeptidase (LAP-EC 3.4.11.1), Malato Desedrogenase (MDH-EC 1.1.1.37), Isocitrato Desidrogenase (IDH-EC 1.1.1.42), Menadiona Redutase (MR-EC 1.6.99.2), e a 6-Fosfogluconato Desidrogenase (6PGDH-EC 1.1.1.44). As reações isoenzimáticas foram baseadas em Alfenas (1998). Porém, com a finalidade de melhorar a resolução da enzima Fosfogluco Isomerase (PGI), optou-se pela alteração na quantidade da enzima Glucose-6-Fosfato Desidrogenase de 6,5 $\mu 1$ para 7,5 $\mu$ l (Figuras 2 e 3, do capítulo 3).

\subsubsection{Análise estatística}

\section{a) Parâmetros do sistema de reprodução}

O sistema de reprodução de $M$. scabrella foi caracterizado para cada procedência e para o conjunto das procedências, utilizando o modelo misto de reprodução (Ritland \& Jain (1981) e modelo de cruzamentos correlacionados (Ritland, 1989), usando o programa "Multilocos MLTR" (Ritland, 1997). O modelo misto assume que as progênies resultam de uma mistura de autofecundação e cruzamento e o modelo de cruzamentos correlacionados assume que a parte originada de cruzamentos foi gerada parte por cruzamentos aleatórios e parte por cruzamentos biparentais. Os parâmetros estimados foram: taxa de cruzamento multilocos $\left(\hat{t}_{m}\right)$, taxa média de cruzamento uniloco $\left(\hat{t}_{s}\right)$, taxa de cruzamento entre parentes $\left(\hat{t}_{m}-\hat{t}_{s}\right)$, correlação de autofecundação $\left(\hat{r}_{s}\right)$, correlação de paternidade $\left(\hat{r}_{p}\right)$ e, coeficiente de endogamia na geração parental $(\hat{F})$. 


\section{b) Coeficiente de Correlação de Parentesco}

Com base nos parâmetros do sistema de reprodução, estimou-se o coeficiente de correlação de parentesco $\left(r_{x y}\right)$ entre plantas dentro de progênies, com base no modelo de Ritland (1989):

$$
r_{x y}=0,25(1+\hat{F})\left(4 \hat{s}+\left(\hat{t}+\hat{s} \hat{t} \hat{r}_{s}\right)\left(1+\hat{r}_{p}\right)\right]
$$

\section{c) Análise de variância}

A análise de variância para o caráter altura foi obtida usando o programa SAS (SAS, 2000) com base no seguinte modelo estatístico,

$$
Y_{i j k l}=m+r_{i}+s_{j}+p s_{k(j)}+p r_{j i}+p s r_{k(j / i)}+e_{(i j k l)}
$$

em que:

$Y_{i j k l}=$ valor do caráter medido na $l$-ésima planta, da $k$-ésima progênie, da $j$ ésima procedência, da $i$-ésima repetição;

$m=$ média geral do caracter;

$r_{i}=$ efeito da repetição $i$;

$s_{j}=$ efeito da procedência $j$;

$p s_{k(j)}=$ efeito da $k$-ésima progênie dentro da $j$-ésima procedência;

$p r_{j i}=$ efeito da interação da $j$-ésima procedência com a $i$-ésima repetição;

$p s r_{k(j / i)}=$ efeito da interação da $k$-ésima progênie, com a $j$-ésima procedência, e com a $i$-ésima repetição;

$e_{(i j k l)}=$ efeito da $l$-ésima planta, dentro da $k$-ésima progênie, da $j$-ésima procedência, na $i$-ésima repetição.

Os componentes de variância foram obtidos da análise de variância usando o procedimento VARCOM em combinação com a rotina RELM, devido ao número desigual de progênies por procedência e a mortalidade diferencial entre subparcelas. A partir dois componentes de variância foram estimados os parâmetros genéticos. 


\section{d) Variância genética aditiva}

A variância genética aditiva para as procedências de $M$. scabrella foi estimada usando dois modelos: o modelo aleatório e o modelo misto de reprodução.

i) Modelo aleatório de reprodução: assume que cada planta de uma progênie foi gerada por um parental paterno diferente, de forma que as progênies são aparentadas como meios-irmãos (MI). A variância genética aditiva é obtida por:

$$
\hat{\sigma}_{A}^{2}=\frac{\hat{\sigma}_{p}^{2}}{\hat{r}_{x y}}
$$

e como em meios-irmãos a correlação de parentesco dentro de progênies $\left(r_{x y}\right)$ é 0,25, tem-se que:

$$
\hat{\sigma}_{A}^{2}=\frac{\hat{\sigma}_{p}^{2}}{0,25}=4 \hat{\sigma}_{p}^{2}
$$

ii) Modelo misto de reprodução: assume que as planta de uma progênie podem ter sido geradas por qualquer forma de reprodução, como autofecundações, cruzamentos aleatórios e cruzamentos biparentais, de forma que as progênies podem conter diferentes graus de parentesco como irmãos de autofecundação (IA), meios-irmãos (MI), irmãos-completos (IC) e irmãos de cruza,mento e autofecundação. A variância genética aditiva é obtida por:

$$
\hat{\sigma}_{A}^{2}=\frac{\hat{\sigma}_{p}^{2}}{\hat{r}_{x y}}
$$


sendo a correlação de parentesco dentro de progênies $\left(r_{x y}\right)$ estimada por, $r_{x y}=0,25(1+\hat{F})\left(4 \hat{s}+\left(\hat{t}+\hat{s} \hat{t} \hat{r}_{s}\right)\left(1+\hat{r}_{p}\right)\right]$, como anteriormente descrito.

\section{e) Parâmetros genéticos}

Os coeficientes de herdabilidade no sentido restrito em nível de plantas individuais $\left(\hat{h}_{i}^{2}\right)$, médio entre progênies $\left(\hat{h}_{m}^{2}\right)$, dentro de progênies $\left(\hat{h}_{d}^{2}\right)$, foram estimados conforme Vencovsky \& Barriga (1992):

$$
\begin{gathered}
\hat{h}_{i}^{2}=\frac{\hat{\sigma}_{A}^{2}}{\hat{\sigma}_{p}^{2}+\hat{\sigma}_{e b}^{2}+\hat{\sigma}_{d}^{2}} \\
\hat{h}_{m}^{2}=\frac{\hat{\sigma}_{p}^{2}}{\hat{\sigma}_{p}^{2}+\frac{\hat{\sigma}_{e b}^{2}}{J}+\frac{\hat{\sigma}_{d}^{2}}{\bar{n} J}} \\
\hat{h}_{d}^{2}=\frac{\left(1-r_{x y}\right) \hat{\sigma}_{A}^{2}}{\hat{\sigma}_{d}^{2}}
\end{gathered}
$$

Os índices $J, K, I, \bar{n}$ e as variâncias já foram previamente definidos.

Os ganhos esperados pela seleção foram preditos conforme Falconer (1987):

i) Ganho esperado na seleção entre progênies:

$$
\begin{array}{ll}
\text { i) Ganho esperado na seleção entre progênies: } & G s_{e}=i_{e} \hat{\sigma}_{p} \hat{h}_{m}^{2} \\
\text { ii) Ganho na seleção dentro de progênies: } & G s_{d}=i_{d} \hat{\sigma}_{d} \hat{h}_{d}^{2}
\end{array}
$$$$
\text { iii) Ganho na seleção entre e dentro de progênies: } G s_{e+d}=i_{e} \hat{\sigma}_{p} \hat{h}_{m}^{2}+i_{d} \hat{\sigma}_{d} \hat{h}_{d}^{2}
$$

Os índices de seleção foram estipulados objetivando selecionar $25 \%$ das progênies de melhor performance $\left(i_{e}=1,271\right)$, e os três melhores indivíduos de cada 30 pertencentes a uma progênie $\left(i_{d}=1,673\right)$ (Hallauer \& Miranda Filho, 1988). 


\subsection{Resultados}

\subsubsection{Parâmetros do sistema de reprodução e coeficiente de correlação de parentesco}

As estimativas dos parâmetros do sistema de reprodução para as procedências são apresentadas na Tabela 18. A taxa de cruzamento multilocus $\left(\hat{t}_{m}\right)$ média entre procedências foi de 0,971 , o valor mínimo foi 0,859 e o máximo 1,00. As estimativas da taxa de cruzamento unilocus foram sempre menores do que a multilocus, sugerindo a ocorrência de cruzamento entre parentes. A diferença entre a taxa de cruzamento multilocus e unilocus $\left(\hat{t}_{m}-\hat{t}_{s}\right)$ variou entre procedências de 0,012 a 0,105, com média de 0,076. A correlação de autofecundação $\left(\hat{r}_{s}\right)$ média entre as procedências foi de 0,091 , variando de 0,013 a 0,109 . A estimativa da correlação de paternidade $\left(\hat{r}_{P}\right)$ variou de 0,153 a 0,694, com média entre procedências de 0,513. A estimativa média do coeficiente de parentesco $\left(\hat{r}_{x y}\right)$ entre procedências foi de 0,392 , variando de valores próximos ao esperado em progênies de meios-irmãos $(0,290)$ e próximos ao esperado em irmãos-completos $(0,440)$.

\subsubsection{Análise de variância}

O Teste $F$ da análise de variância revelou diferenças significativas entre procedências para o caráter altura (Tabela 19), mas ausência de diferenças estatísticas entre progênies dentro de populações. 
Tabela 18. Estimativa de parâmetros do sistema de reprodução em nove populações de M. scabrella

\begin{tabular}{cccccccccccc}
\hline Parâmetros & Itararé & $\begin{array}{c}\text { Piraí do } \\
\text { Sul }\end{array}$ & $\begin{array}{c}\text { Mandi- } \\
\text { rituba }\end{array}$ & Lapa & $\begin{array}{c}\text { Procedências } \\
\text { Honório } \\
\text { Serpa }\end{array}$ & $\begin{array}{c}\text { Turvo } \\
\text { Caça- } \\
\text { dor }\end{array}$ & $\begin{array}{c}\text { Itupor. } \\
\text { nativa }\end{array}$ & $\begin{array}{c}\text { Itupor. } \\
\text { Comer. }\end{array}$ & Espécie \\
\hline$\hat{F}$ & 0 & 0 & 0 & 0,004 & 0,004 & 0 & 0 & 0,004 & 0 & 0,012 \\
$\hat{t}_{m}$ & 0,949 & 1,000 & 1,000 & 1,000 & 0,979 & 0,859 & 0,945 & 1,000 & 0,958 & $0,971^{*}$ \\
$\hat{t}_{s}$ & 0,877 & 0,985 & 0,923 & 0,913 & 0,917 & 0,801 & 0,933 & 0,926 & 0,853 & 0,895 \\
$\hat{t}_{m}-\hat{t}_{s}$ & 0,072 & 0,015 & 0,077 & 0,087 & 0,062 & 0,058 & 0,012 & 0,074 & 0,105 & 0,076 \\
$\hat{r}_{s}$ & 0,026 & 0,109 & 0,109 & 0,113 & 0,095 & 0,013 & 0,310 & 0,107 & 0,052 & 0,091 \\
$\hat{r}_{P}$ & 0,521 & 0,449 & 0,477 & 0,153 & 0,244 & 0,476 & 0,694 & 0,495 & 0,529 & 0,513 \\
$\hat{r}_{x y}$ & 0,396 & 0,362 & 0,370 & 0,290 & 0,320 & 0,414 & 0,440 & 0,376 & 0,394 & 0,392 \\
\hline
\end{tabular}

Tabela 19. Significância do teste $F$ para o caráter altura aos seis meses, para as nove populações de M. scabrella

\begin{tabular}{lclc}
\hline \multicolumn{1}{c}{ Fonte de variação } & GL & QM & $F$ \\
\hline Bloco & 4 & 0,9359 & $5,92^{*}$ \\
Procedência & 8 & 0,7726 & $4,75^{*}$ \\
Progênie/Procedência & 130 & 0,1633 & 1,03 \\
Erro b & 482 & 0,1591 & \\
Erro Dentro & 3,22 & 0,0453 & \\
\hline tal & 3,46 & & \\
$* P>0,05$. & & &
\end{tabular}

\subsubsection{Componentes da variância}

Os componentes da variância para a análise desdobrada dos efeitos de progênies dentro de procedências são apresentados na Tabela 20. O componente que mais contribuiu para a variância fenotípica total $\left(\hat{\sigma}_{F}^{2}\right)$, em todas as procedências, foi à variância fenotípica dentro de progênies $\left(\hat{\sigma}_{d}^{2}\right)$, seguido pela variância ambiental $\left(\hat{\sigma}_{e}^{2}\right)$ e variância genética entre progênies $\left(\hat{\sigma}_{p}^{2}\right)$. Portanto, os fenótipos das árvores foram 
influenciados principalmente por efeitos ambientais e, em menor escala, pela variação genética entre progênies.

Comparando as procedências, a Caçador foi a que apresentou maior variação genética entre progênies $\left(\hat{\sigma}_{p}^{2}\right)$ e a Piraí do Sul a menor variação genética. Esse resultado leva a crer que maiores ganhos genéticos poderão ser capitalizados na seleção dentro da procedência de Caçador.

Tabela 20. Componentes da variância fenotípica dentro de progênies $\left(\hat{\sigma}_{d}^{2}\right)$, ambiental entre parcelas $\left(\hat{\sigma}_{e}^{2}\right)$, genética entre progênies $\left(\hat{\sigma}_{p}^{2}\right)$ e fenotípico total $\left(\hat{\sigma}_{F}^{2}\right)$ em M. scabrella

\begin{tabular}{lcccc}
\hline \multicolumn{1}{c}{ Procedência } & $\hat{\sigma}_{d}^{2}$ & $\hat{\sigma}_{e}^{2}$ & $\hat{\sigma}_{p}^{2}$ & $\hat{\sigma}_{F}^{2}$ \\
\hline Itararé - SP & 0,0341 & 0,0195 & 0,0012 & 0,0548 \\
Piraí do Sul - PR & 0,0542 & 0,0195 & 0,0007 & 0,0744 \\
Mandirituba - PR & 0,0431 & 0,0195 & 0,0025 & 0,0651 \\
Lapa - PR & 0.0498 & 0,0195 & 0,0023 & 0,0716 \\
Honório Serpa - PR & 0,0419 & 0,0195 & 0,0023 & 0,0637 \\
Turvo - PR & 0,0427 & 0,0195 & 0,0004 & 0,0626 \\
Caçador - SC & 0,0494 & 0,0195 & 0,0043 & 0,0732 \\
Ituporanga - SC (nativa) & 0,0400 & 0,0195 & 0,0012 & 0,0607 \\
Ituporanga - SC (comercial) & 0,0547 & 0,0195 & 0,0039 & 0,0781 \\
\hline
\end{tabular}

\subsubsection{Parâmetros genéticos}

As estimativas dos coeficientes de variação genética, variância fenotípica dentro de progênies, da variância genética aditiva e dos coeficientes de herdabilidade encontram-se na Tabela 21. O coeficiente de variação genética variou entre procedências de 2,35\% (Turvo) a 8,30\% (Caçador), com média de 2,38\%. O coeficiente de variação fenotípica dentro detectado para a média das procedências de $M$. scabrella, variou de $20,83 \%$ a $29,47 \%$, com média de $25,57 \%$. 
A variância genética aditiva, as herdabilidades em nível de plantas individuais e fenotípica dentro de progênies e os ganho na seleção dentro de progênies e entre e dentro de progênies foram estimadas para dois modelos, assumindo progênies de polinização aberta como sendo meios irmãos, MI (modelo aleatório de reprodução) e como sendo misturas de diferentes graus de parentesco, MS (modelo misto de reprodução) (Tabelas 21 e 22). Todos estes parâmetros apresentaram resultados superestimados quando o modelo aleatório de reprodução foi assumido, com exceção da herdabilidade em nível de média de progênies $\left(\hat{h}_{m}^{2}\right)$ e ganhos esperados na seleção entre progênies $\left(G s_{e}\right)$. A superestimativa na variância genética $\left(\hat{\sigma}_{A}^{2}\right)$ aditiva e na herdabilidade em nível de plantas individuais $\left(\hat{h}_{i}^{2}\right)$ foi a mesma, variando de $13,97 \%$ (Lapa) a 54,55\% (Caçador), com média entre procedências de $36,22 \%$. A superestimativa na herdabilidade entre plantas dentro de progênies $\left(\hat{h}_{d}^{2}\right)$ foi maior que a detectada na herdabilidade em nível de plantas individuais e foi a mesma que a observada no ganho esperado na seleção entre plantas dentro de progênies, variando de 18,39\% (Lapa) a 72,73\% (Caçador), com média de $48,30 \%$. A superestimativa no ganho esperado na seleção entre e dentro de progênies $\left(G s_{e+d}\right)$ variou entre procedências de $13,73 \%$ (Lapa) a 53,07\% (Caçador), com média entre procedências de 40,86\% (Tabela 22).

A variância genética aditiva $\left(\hat{\sigma}_{A}^{2}\right)$ estimada para o modelo misto de reprodução variou entre procedências de 0,0010 (Turvo) a 0,0099 (Ituporanga comercial) com média de 0,0016. A herdabilidade em nível de média de progênies $\left(\hat{h}_{m}^{2}\right)$ foi superior as demais estimativas de herdabilidade, variando entre procedências de valores baixos 0,0775 (Turvo) a médios 0,4561 (Caçador), com média entre procedências de 0,068. O coeficiente de herdabilidade em nível de plantas $\left(\hat{h}_{i}^{2}\right)$ e dentro de progênies $\left(\hat{h}_{d}^{2}\right)$ apresentaram valores similares entre as mesmas procedências e variaram de baixos (0,0255, população Turvo-PR) a moderados (0,2250, população Caçador, SC).

A estimativa dos ganhos esperados na seleção entre progênies $\left(G s_{e}\right)$ foram baixas, variando de 0,23\% (Lapa) a 4,81\% (Caçador), com média de 0,20\% e inferiores 
aos observados nas estimativas dos ganhos esperados na seleção dentro de progênies $\left(G s_{d}\right)$ para o modelo misto de reprodução, que variou entre procedências de 0,54\% (Turvo) a 5,21\% (Lapa). Os ganhos esperados na seleção entre e dentro de progênies $\left(G s_{e+d}\right)$ foram em geral baixos, variando de $0,74 \%$ (Turvo) a 8,89\% (Ituporanga comercial), com média de $0,71 \%$. 


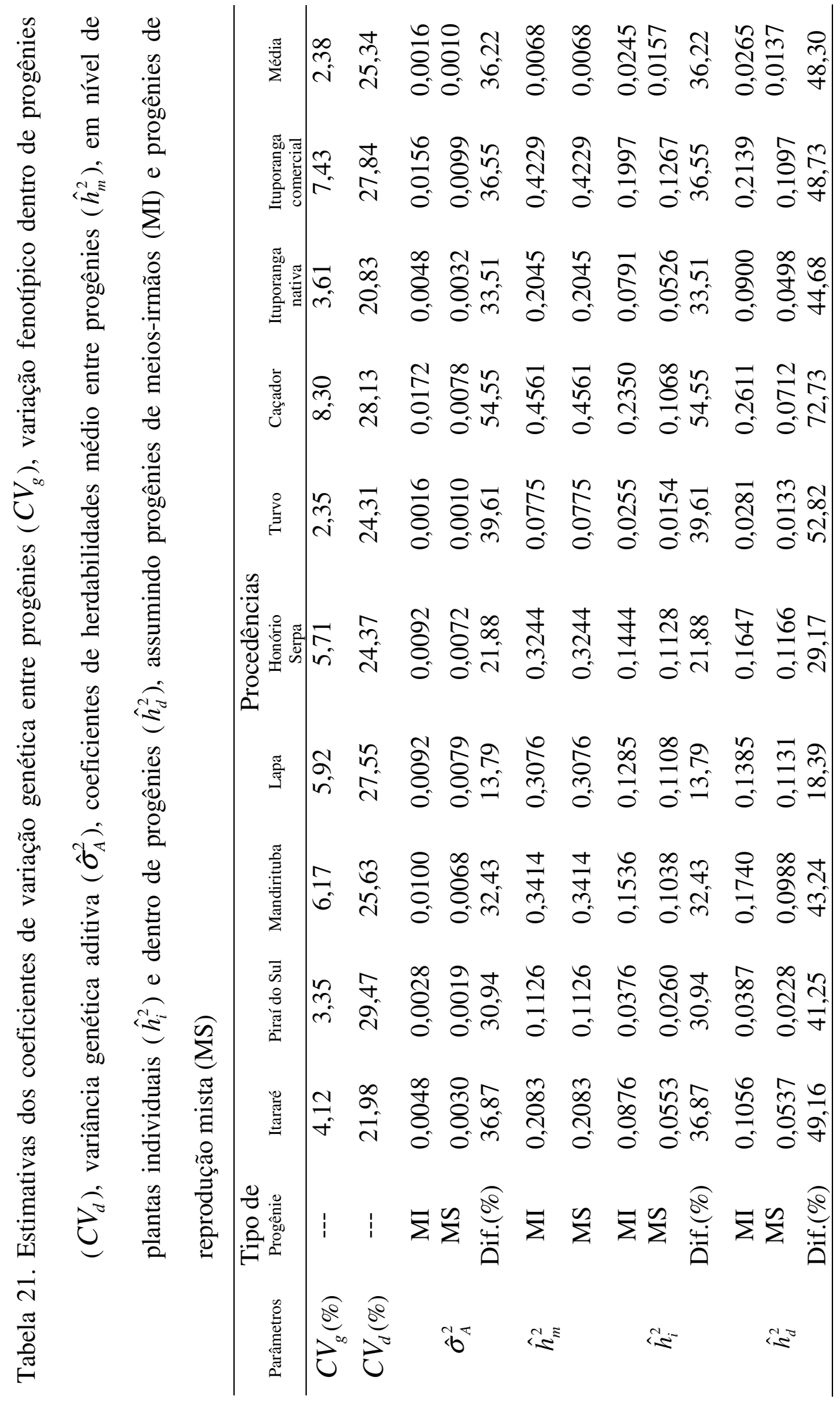




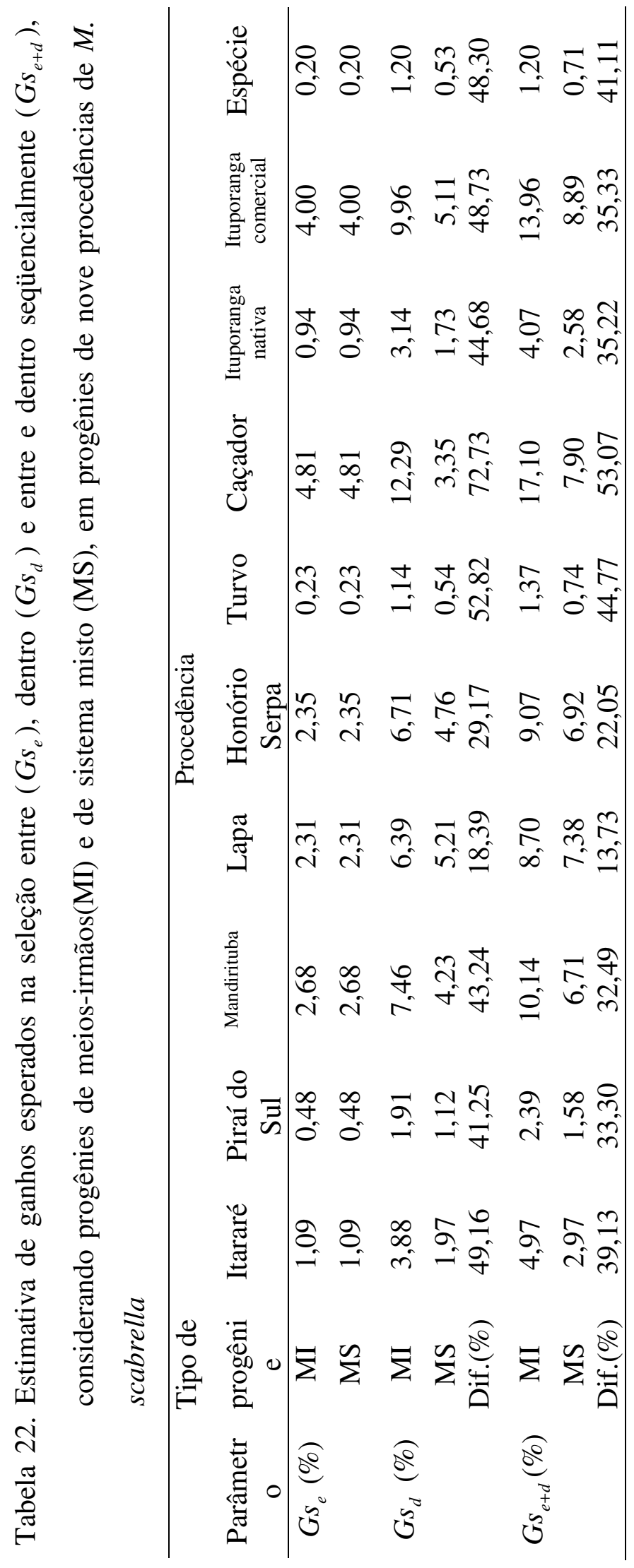




\subsection{Discussões}

\subsubsection{Parâmetros do sistema de reprodução e coeficiente de correlação de parentesco}

A análise do sistema de reprodução das procedências de $M$. scabrella indicou que a espécie apresenta sistema misto de reprodução $\left(\hat{t}_{m}\right.$ variando de 0,859 a 1,00$)$ com predomínio de cruzamentos (Tabela 18). A diferença entre a taxa de cruzamento multilocus e unilocus $\left(\hat{t}_{m}-\hat{t}_{s}\right.$, variando de 0,012 a 0,105$)$ detectou que parte dos cruzamentos ocorreram entre indivíduos parentes. Por sua vez, a estimativa da correlação de paternidade $\left(\hat{r}_{P}\right)$ sugere que parte das progênies de cruzamento são parentes no grau de irmãos-completos (variando de 15,3\% a 69,4\% das progênies). Em concordância, a estimativa do coeficiente de parentesco $\left(\hat{r}_{x y}\right)$ entre plantas dentro de progênies (variando de 0,290 a 440) foi muito superior ao esperado em progênies de meios-irmãos $(0,25)$. A estimativa média entre procedências para o coeficiente $\hat{r}_{x y}$ $(0,392)$ foi $36,2 \%$ superior ao esperado em progênies de meios-irmãos $(0,125)$. Assim, evidentemente, assumir que progênies de polinização aberta de M. scabrella são meiosirmãos, causará forte superestimativa na variância genética aditiva e parâmetros dependentes dessa, como herdabilidade em nível de plantas individuais, herdabilidade média dentro de progênies, ganhos esperados na seleção dentro de progênies e ganho esperado na seleção entre e dentro de progênies.

\subsubsection{Análise de variância}

O Teste $F$ da análise de variância revelou diferenças significativas em altura de plantas entre procedências (Tabela 19), demonstrando a possibilidade de obter-se ganhos pela seleção entre procedências. Contudo, entre progênies dentro de procedências não foram detectadas diferenças significativas. A ausência de diferenças entre progênies dentro de procedências pode estar associada à precocidade das plantas. A avaliação aos seis meses é preliminar e o ensaio deverá ser novamente mensurado em fases mais avançadas de desenvolvimento. Comparando a estimativa da variância genética $\left(\hat{\sigma}_{p}^{2}\right)$ entre as procedências, a Caçador foi a que apresentou maior variação genética e a Piraí 
do Sul a menor, levando a crer que maiores ganhos genéticos poderão ser capitalizados na seleção dentro da procedência Caçador.

\subsubsection{Coeficientes de variação}

O coeficiente de variação genética entre progênies $\left(C V_{g}\right)$ variou entre procedências de 2,35\% (Turvo) a 8,30\% (Caçador) com média de 2,38\%. Comparado com o coeficiente de variação genética obtida por Dias (1988) para altura de árvores de M. scabrella, aos quatro anos de idade, para três procedências da espécie (variando de $0,6 \%$ a 3,4\%), pode-se afirmar que a variação genética expressão no presente ensaio, até a presente data, é superior. Comparando o $C V_{g}$ obtido para a procedência Itararé $(4,12 \%)$ com o obtido em por Dias (1988) para a mesma procedência $(0,6 \%)$ fica novamente evidente a maior expressão de variação genética do material, aos seis meses de idade nas condições de Itatinga, relativamente as condições ambientais do experimento de Dias (1988) em Itararé. Por outro lado, o valor médio do coeficiente $C V_{g}$ é inferior ao relatado por Sebbenn (2001) para a média de 15 espécies arbóreas nativas $\left(C V_{g}=7,49 \%\right)$, sugerindo que, em termos médios, as procedências de $M$. scabrella apresentam baixa variação genética, comparada a outras espécies nativas.

O coeficiente de variação fenotípica dentro de progênies detectado para a média das procedências de $M$. scabrella $(25,57 \%)$ foi superior ao encontrado para a média do crescimento em altura de 15 espécies arbóreas Sebbenn (2001; 25,36\%). Tal informação é importante porque, em espécies de cruzamento como as arbóreas, grande parte da variância genética aditiva encontra-se dentro de progênies (até $75 \%$ ) e ganhos genéticos podem ser capitalizados pela seleção seqüencial das melhores plantas das melhores progênies. Em termos gerais, a magnitude de ambos os coeficientes de variação genética entre progênies e fenotípico dentro de progênies, indica que maiores ganhos na seleção podem ser esperados na procedência de Caçador. 


\subsubsection{Variância genética aditiva}

A estimativa da variância genética aditiva $\left(\hat{\sigma}_{A}^{2}\right)$ e dos parâmetros genéticos para os modelos aleatório (MI) e misto de reprodução (MS) detectou forte superestimativas quando o modelo aleatório foi usado ao invés do modelo misto de reprodução (Tabelas 21 e 22). A procedência Lapa (PR) foi a que apresentou a menor superestimativa em todos os parâmetros e a Caçador (SC) a maior. A causa é o sistema de reprodução. A procedência de Lapa teve a maior taxa de cruzamento estimada (1,00), a menor correlação de paternidade $(0,153)$ e, conseqüentemente, o coeficiente de parentesco $(0,290)$ mais próximo ao esperado em progênies de meios-irmãos $(0,25)$. Por outro lado, a procedência de Caçador apresentou taxa de cruzamento $(0,945)$ menor do que a unidade e a maior estimativa da correlação de paternidade $(0,694)$, indicando que aproximadamente $70 \%$ das progênies geradas por cruzamentos eram parentes no grau de irmãos-completos. Em conseqüência disso, o coeficiente de parentesco entre plantas dentro de progênies assumiu valor $(0,440)$ próximo ao esperado em progênies de irmãoscompletos $(0,5)$. O erro na suposição da forma de reprodução na procedência de Caçador e, conseqüentemente, no grau médio de parentesco entre plantas dentro das progênies resultou na superestimativa da variância genética aditiva em 54,55\%.

Os outros parâmetros genéticos dependentes da variância genética aditiva como herdabilidade entre plantas dentro de progênies e ganhos esperados na seleção dentro de progênies e entre e dentro de progênies seguiram o comportamento da variância genética aditiva, com valores fortemente superestimados quando o modelo aleatório de reprodução foi empregado ao invés do modelo misto de reprodução. Superestimativas em parâmetros genéticos em espécies arbóreas quando o modelo aleatório é usado ao invés do modelo misto de reprodução, são relatados em diversos outros estudos. Surles et al. (1990) detectaram em Robinia pseudoacacia, superestimativas no ganhos esperados na seleção de até $38 \%$ quando o modelo aleatório foi usado ao invés do modelo misto. Askew \& El-kassaby (1994) corrigiram a estimativa do coeficiente de herdabilidade em nível de plantas individuais, em cedro vermelho do oeste, usando o 
modelo de Cockerham \& Weir (1984), baseado na estimativa do coeficiente de parentesco entre plantas dentro de progênies a partir do coeficiente de endogamia estimado da taxa de autofecundação assumindo o equilíbrio de endogamia. Observou-se superestimativas na herdabilidade de $29 \%$ quando as progênies foram assumidas como meios-irmãos (Askew \& El-kassaby, 1994). Usando o modelo de Cockerham \& Weir (1984) para estimar o coeficiente de parentesco entre plantas dentro de progênies, Costa et al. (2000) estudando progênies de polinização aberta de Hevea brasiliensis detectaram superestimativas nos ganhos esperados na seleção de até 30,5\%, quando o modelo aleatório foi usado ao invés do modelo misto de reprodução. Sebbenn \& Ettori (2001) compararam as estimativas de parâmetros genéticos em teste de progênies combinado de Esenbeckia leiocarpa, Myracrodruon urundeuva e Peltophorum dubium e detectaram superestimativas na variância genética aditiva variando de $40 \%$ a $50 \%$. Sebbenn et al. (2002a), por sua vez, comparando a estimativa de parâmetros genéticos em Cariniana legalis obtidas com base no modelo aleatório e no modelo misto de reprodução de Ritland (1989) detectaram superestimativas nos ganhos esperados na seleção de até 33\%. Fato interessante nos resultados dessa espécie é que, mesmo a taxa de cruzamento sendo praticamente 1,0 , houve interferência na estimativa da variância genética aditiva. Isso porque o modelo utilizado pelos autores além de ponderar a autofecundação, também admite os cruzamentos biparentais nas suas análises (Sebbenn et al., 2002a).

As superestimativas da variância genética aditiva, herdabilidades e ganhos esperados na seleção ocorrem porque se presume que as progênies de polinização aberta retém 1/4 da variância genética aditiva e o coeficiente de correlação de parentesco de 0,25. Essa pressuposição é valida somente quando não existe endogamia e parentesco na geração parental, a espécie é perfeitamente alógama, não ocorram cruzamentos biparentais e um grande número de polinizadores participam da reprodução. Se um dos fatores, ou ambos, acima citados não for(em) cumprido(s), haverá uma redistribuição da variância genética aditiva entre e dentro de progênies e a incorporação de parte da variância genética de dominância, levando a uma superestimação da variância aditiva (Sebbenn et al., 2002a). 
Em suma, o modelo aleatório de reprodução, que assume que progênies de polinização aberta são aparentadas no grau de meios-irmãos, não é adequando para descrever a herança de caracteres quantitativos em de M.scabrella, devido a seu sistema misto de reprodução.

\subsubsection{Coeficientes de herdabilidade}

Os coeficientes de herdabilidades em nível de plantas $\left(\hat{h}_{i}^{2}\right)$ e dentro de progênies

$\left(\hat{h}_{d}^{2}\right)$ estimados para o modelo misto de reprodução foram similares entre mesmas procedências e variaram de baixos (0,0154, procedência Turvo-PR) a moderados $(0,1267$, procedência Ituporanga comercial). Por sua vez, o coeficiente de herdabilidade em nível de media de progênies $\left(\hat{h}_{m}^{2}\right)$ variou de baixo $(0,0775$, procedência Turvo-PR), a alto $(0,4561$, procedência Caçador, SC). Esses resultados, primeiro indicam que as procedências apresentam diferentes potenciais para a seleção, ou seja, algumas apresentam maior controle genético sobre o fenótipo, portanto, maiores chances de progressos genéticos pela seleção. Segundo, os resultados indicam que maiores ganhos poderão ser obtidos pela seleção entre progênies, relativamente a entre plantas no experimento (seleção massal) e entre plantas dentro de progênies (seleção massal dentro de progênies). O uso da seleção seqüencial entre e dentro de progênies é sem duvida mais adequado, ou ainda, o uso da seleção com base em valores genéticos a partir de índices de seleção, como o índice multi-efeitos (Resende \& Higa, 1994).

\subsubsection{Ganhos na seleção}

As procedências que apresentaram maiores coeficientes de variação genética e herdabilidades (Caçador, Ituporanga - comercial, e Mandirituba), também obtiveram as melhores perspectivas de ganhos na seleção. Os ganhos esperados, mesmo com a correção a partir do modelo misto de reprodução, foram altos, atingindo até 8,89\%. Contudo, essas estimativas são preliminares e o ideal para a capitalização de ganhos 
genéticos é a seleção na metade do ciclo de rotação da espécie (Zobel \& Talbert, 1984), algo em torno de quatro a cinco anos para M.scabrella. 


\section{CONCLUSÕES}

1. M. scabrella reproduz-se por sistema misto de reprodução, com predomínio de cruzamentos;

2. Parte dos cruzamentos nas populações de $M$. scabrella ocorre entre parentes;

3. Progênies de polinização aberta de $M$. scabrella podem ser compostas por misturas de irmãos de autofecundação, meios-irmãos, irmãos-completos e irmãos de cruzamento e autofecundação;

4. Aparentemente, existe forte seleção contra indivíduos endogâmicos entre a fase de plântulas e a fase adulta;

5. M. scabrella tem altos níveis de diversidade genética quando comparada a outras espécies arbóreas tropicas;

6. Existe baixa divergência genética entre as procedências de $M$. scabrella para locos isoenzimáticos, provavelmente, devido ao intenso fluxo gênico ocorrido no passado;

7. A divergência genética entre procedências, aparentemente, não pode ser explicada pelo modelo de isolamento por distância;

8. Existem diferenças genéticas entre procedências para o caráter altura;

9. A maior parte da variação quantitativa total e isoenzimática encontra-se dentro de procedências;

10. A variação entre procedências aos seis anos de idade é maior para o caráter altura relativamente as isoenzimas, portanto, a divergência genética quantitativa entre procedências pode ser explicada principalmente pelos efeitos da seleção natural; 
11. A variação genética quantitativa entre progênies dentro de procedências é menor do que a observada pelas isoenzimas, de forma que a diferença quantitativa entre as progênies pode ser atribuída aos efeitos da deriva genética;

12. A avaliação da herança de caracteres quantitativos em testes de progênies de M. scabrella baseados em progênies de polinização aberta deve ser realizadas utilizando modelos que acomodem desvios da pressuposição de cruzamentos aleatórios. 


\section{REFERÊNCIAS BIBLIOGRÁFICAS}

ALFENAS, S.A. Eletroforese de isoenzimas e proteínas afins: Fundamentos e aplicações em plantas e microorganismos. Viçosa: Universidade Federal de Viçosa, 1998. 574p.

ALLARD, R.W. Princípios do melhoramento genético das plantas. São Paulo: Edgard Blucher, 1971. 381p.

ALVES, R.M.; SEBBENN, A.M. FIGUEIRA, A. Mating system in natural population of Theobroma grandiflorum (Willd ex Spreng) Shumm genetics and molecular. Biology, v.79, n. 2, p.20-31. 2003.

ASKEW, G.R.; EL-KASSABY, Y.A. Estimation of relationship coefficients among progeny derived from wind-pollinated orchard seeds. Theoretical and Applied Genetics, v.88, p.267-272, 1994.

AULER, N.M.F.; REIS, M.S. dos; GUERRA, M.P.; NODARI, R.O. The genetics and conservation of Araucaria angustifolia: Genetic structure and diversity of natural populations by means of non-adaptative variation in the state of Santa Catarina, Brazil. Genetics and Molecular Biology, v.25, n.3, p.239-338, 2002.

BALERONI, C.R.S.; ALVES, P.F.; SANTOS, E.B.R.; CAMBUIM, J.; ANDRADE, J.A.C.; MORAES, M.L.T. Variação genética em populações naturais de aroeira em dois sistemas de plantio. Revista do Instituto Florestal, v.15, n.2, p.125-136, 2003.

BARROSO, G.M.; MORIM, M.P.; PEIXOTO, A.L.; ICHASO, C.L.F. Frutos e Sementes: morfologia aplicada à sistemática de dicotiledôneas. Viçosa: Universidade Federal de Viçosa, 1999. 443p. 
BAWA, K.S. Breeding systems of tree species for a lowland tropical community. Evolution, v.28, p.85-92, 1974.

BRIDGWATER, F.Mating desing. In: FINS, L.; FRIEDMAN, S.T.; BROTSCHOL.

Handbook of quantitative forest genetics. Dordrecht: Kluwer Academic Publishers, 1992. p. 69-89,.

BROWN, A.H.D. Isozymes, plant populations genetics structure and genetic conservation. Theoretical and Applied Genetics, v. 52, p. 145-157, 1978.

BUTCHER, P.A.; WILLIAMS, E.R. Variation in outcrossing rates and grown in Eucalyptus camaldulensis from the Petford Region, Queensland; Evidence of outbreeding depression. Silvae Genetica, v.51, p.65-72, 2002.

CARDOSO, J. Bracatinga. Curitiba: Brasil Madeira, v.3, n.33, p.10-11, 1979.

CARPANEZZI, A.A. Banco de sementes e deposição de folhedo e seus nutrientes em povoamentos de bracatinga (Mimosa scabrella Bentham) na região metropolitana de Curitiba - PR. Rio Claro, 1997. 177p. Tese (Doutorado) - Universidade Estadual Paulista "Julio de Mesquita Filho".

CARPANEZZI, A.A.; COSTA, L.G.S.; KAGEYAMA, P.Y.; CASTRO, C.F.A. Funções múltiplas das florestas: conservação e recuperação do meio ambiente. CONGRESSO FLORESTAL BRASILEIRO, 6.,Campos do Jordão, 1990. Anais. Campos do Jordão: s. ed., 1990. v3. p. 216-21.

CARPANEZZI, O.T.B. Produtividade florestal e agrícola em sistemas de cultivo da bracatinga (Mimosa scabrella Bentham) em Bocaiúva do Sul, região metropolitana de Curitiba - PR. Piracicaba, 1994. 77p. Dissertação (Mestrado) - Escola Superior de Agricultura "Luiz de Queiróz" - Universidade de São Paulo.

CARVALHO, P.E.R. Comportamento da bracatinga (Mimosa scabrella Bentham) em plantios experimentais. In.: SEMINÁRIO SOBRE ATUALIDADES E PERSPECTIVAS FLORESTAIS. "BRACATINGA: UMA ALTERNATIVA PARA O REFlORESTAMENTO”, 4., Curitiba, 1981. Anais. Curitiba: s. ed., 1981a. p.53-65. 
CARVALHO, P.E.R. Composição e crescimento de um povoamento natural de bracatinga (Mimosa scabrella Bentham). SEMINÁRIO SOBRE ATUALIDADES E PERSPECTIVAS FLORESTAIS. "BRACATINGA: UMA ALTERNATIVA PARA O REFLORESTAMENTO”, 4., Curitiba, 1981. Anais. Curitiba: s. ed., 1981b. p.67-75.

CARVALHO, P.E.R. Espécies florestais brasileiras: recomendações silviculturais, potencialidades e uso da madeira. Colombo: EMBRAPA-CNPF; Brasília: EMBRAPA-SPI, 1994. 640p.

CATHARINO, E.L.M.; CRESTANA, C.S.M.; KAGEYAMA, P.Y. Biologia floral da bracatinga (Mimosa scabrella). Silvicultura em São Paulo, v.16, p.525-31, 1982.

CHESE, M.R.; BOSHIER, D.H.; BAWA, K.S. Population genetics of Cordia alliodora (Boraginaceae), a neotropical tree. 1. Genetic variation in natural populations. American Journal of Botany, v.82, n.4, p.468-475, 1995.

CLEGG, M.T. Measuring plant mating systems. Bioscience, v.30, n.12, p.814-818, 1980.

CLEMENT, C.R. Melhoramento de espécies nativas. In.: NASS, L.L.; VALOIS, A.C.C.; MELO, I.S.; VALADARES-INGLIS, M.C. (Ed.) Recursos genéticos e melhoramento: plantas. Rondonópolis: Fundação MT, 2001. p.423-478.

COCKERHAM, C.C. Variance of gene frequencies. Evolution, v.23, p.72-84, 1969.

COCKERHAM, C.C.; WEIR, B.S. Covariances of relatives stemming a population undegoing mixed self and random mating. Biometrics, v.40, p.157-164, 1984.

COCKERHAM, C.C.; WEIR, B.S. Estimation of gene flow from $F$-statistics. Evolution, v.47, n.3, p.855-863, 1993.

COELHO, A.S.G.; VALVA, F.D. O processo evolutivo e o melhoramento de plantas. In.: NASS, L.L.; VALOIS, A.C.C.; MELO, I.S.; VALADARES-INGLIS, M.C. (Ed.) Recursos genéticos e melhoramento: plantas. Rondonópolis: Fundação MT, 2001. p.57-78. 
COLLEVATTI, R.G.; GRATTAPPAGLIA, D.; HAY, J.D. High resolution microsatellite based analysis of the mating system allows the detection of significant biparental inbreeding in Caryocar brasiliensis, and endangered tropical tree species. Heredity, v.86, p.60-67, 2001.

COSTA, R.B da; RESENDE, M.D.V.; ARAUJO, A.J.; GONÇALVES, P.S.; HIGA, A.R. Selection and genetic gain in rubber tree (Hevea brasiliensis) populations using a mixed mating system. Genetics and Molecular Biology, v.23, n.3, p.671679, 2000.

CROW, J. F.; AOKI, K. Groupselection for a polygenic behavioral trait: estimating the degree of population subdivision. Proceedings of the National Academy of Sciences, v.81, p.6073-6077, 1984.

DIAS, S.D. Variabilidade genética de diferentes tipos de populações naturais de bracatinga Mimosa scabrella Bentham. Piracicaba, 1988. 62p. Dissertação (Mestrado) - Escola Superior de Agricultura "Luiz de Queiróz” - Universidade de São Paulo.

ETTORI, L.C.; SEBBENN, A.M.; SATO, A.; MORAES, E. Teste de procedências de Pinus oocarpa Schiede em três locais do Estado de São Paulo. Revista do Instituto Florestal, v.14, n.1, p.39-51, 2002.

FERREIRA, M.E.; GRATTAPAGLIA, D. Introdução ao uso de marcadores moleculares em análise genética. Brasília: EMBRAPA-CENARGEN, 1998. 220p. (EMBRAPA-CENARGEN Documento, 20).

FONSECA, S.M. Variações fenotípicas e genéticas em bracaatinga (Mimosa scabrella Benthan). Piracicaba, 1982. 86p. Dissertação (Mestrado) - Escola Superior de Agricultura "Luiz de Queiróz" - Universidade de São Paulo.

FUCHS, E.J.; LOBO, J.A.; QUESADA, M. Effects of forest fragmentation and flowering phenology on the reproductive success and mating patterns of the tropical dry forest tree Pachira quinata. Conservation Biology, v.17, n.1, p.149-157, 2003. FUTUYMA, D.J. Biologia evolutiva. 2. ed. Ribeirão Preto: Sociedade Brasileira de Genética/CNPq, 1992. 646p. 
GARRAY-ARROYO, A.; ALVAREZ-BUYLLA, E.R. Isozyme variation in a tropical pioneer tree species (Cecropia obtusifolia, Moraceae) with high contents of secondary compounds. Biotropica, v.29, n.3, p.280-290, 1997.

GHAI, G.L. Covariances among relatives in populations under mixed self-fetilization and random mating. Biometrics, v.38, p.87-92, 1982.

GONZÁLEZ-MARTÍNES, S.C.; ALÍA, R.; GIL, L. Population genetic structure in a Mediterranean pine (Pinus pinaster Ait.): a comparison of allozyme markers and quantitative traits. Heredity, v.89, p.199-206, 2002.

GRAÇA, L.R.; MENDES, J.B. Análise econômica de sistemas de reflorestamento com bracatinga. Boletim de Pesquisas Florestais, v.14, p.55-63, 1987.

GUSSON, E.; SEBBENN, A.M.; KAGEYAMA, P.Y. Sistema de reprodução em populações de Eschweilera ovata (Cambess) Miers. Revista Árvore. (No prelo).

HALLAUER, A.R.; MIRANDA FILHO. ,J.B. Quantitative genetics in maize breeding. Ames: State University Press, 1988. 468 p.

HAMRICK, J.L. Isozymes and analysis of genetic structure in plant populations. In: SOLTIS, D.E.; SOLTIS, P. (Ed.) Isozymes and the analysis of genetic structure in plant populations. New York: Chapman and Hall, 1989. p.87-105.

HAMRICK, J.L.; LINHART, Y.B.; MITTON, J.B. Relationships between life history characteristc and eletrophoretically detectable genetic variation in plants. Annual Review of Ecology and Systematics, v.10, p.173-200, 1979.

HAMRICK, J.L. The distribution of genetic variation within and among natural plant population. In: SCHONE-WALD-COX, C.M.; CHAMBERS, S.H.; MacBYDE, B.; THOMAS, L. Genetics and Conservation. Menlo Park: Benjamin Cummings, 1983. p.35-348.

HAMRICK, J.L.; LOVELESS, M.D. The genetic structure of tropical tree population: associations with reproductive biology. In.: BOOCK, J.H.; LINHEART, Y.B. (Ed.) The Evolucionary Ecology of Plants. Bolder:Westview press, 1989. p.129-146.

HAMRICK, J.L.; GODT, M.J.W. Allozyme diversity in plant species. In: BROWN, A.H.D.; ClEGG, M.T.; KAHLER, A.L.; WEIR, B.S. (Ed.) Plant population genetics, breeding and genetic resources. Sunderland: Sinauer, 1990. p.43-63. 
HARTL, D.L.; CLARK, A.G. Principles of population genetics. 3. ed. Sunderland: Sinauer Associates, 1997. 542p.

HOWE, G.T.; AITKEN, S.N.; NEALE, D.B.; JERMSTAD, K.D.; WHEELER, N.C.; CHEN, T.H.H. From genotype to phenotype: unraveling the complexities of cold adaptation in forest trees. Canadian Journal of Botany, v.81, p.1247-1266, 2003.

IEDE, E.T. Alguns aspectos sobre espécies de insetos que ocorrem na bracatinga (Mimosa scabrella Bentham). In.: SEMINÁRIO SOBRE ATUALIDADES E PERSPECTIVAS FLORESTAIS. "BRACATINGA: UMA ALTERNATIVA PARA O REFlORESTAMENTO”, 4., Curitiba, 1981. Anais. Curitiba: s. ed., 1981. p.91-102.

JARAMILLO-CORREA, J.P.; BEAULIEU, J.; BOUSQUET, J. Contrasting evolutionary forces driving population structure at expressed sequence tag polymorphisms, allozymes and quantitative traids in white spruce. Molecular Ecology, v.10, p.2729-2740, 2001.

KAGEYAMA, P.Y. Conservação in situ dos recursos genéticos de plantas. IPEF, v.35, p.7-48, 1987.

KAGEYAMA, P.Y.; GANDARA, F.B.; VENCOVSKY, R. Conservação in situ de espécies arbóreas tropicais. In.: NASS, L.L.; VALOIS, A.C.C.; MELO, I.S.; VALADARES-INGLIS, M.C. (Ed.) Recursos genéticos e melhoramento: plantas. Rondonópolis: Fundação MT, 2001. p.149-158.

KAGEYAMA, P.Y., SEBBENN, A.M.; RIBAS, L.A.; GANDARA, F.B.; CASTELLEN, M.; CALHEIROS, B.P.; VENCOVSKY, R. Diversidade genética em espécies arbóreas modelo da floresta tropicais atlântica por diferentes marcadores genéticos. Scientia Forestalis, n.64, p.93-107, 2003.

KEMP, R.H. Seed procurement for species and provenance research. In.: BURLEY, J.; WOOD, P.J. A manual on species and provenance research particular reference to the tropics. Oxford: Commonwealth Forestry Institute, 1976. p.3248.

LANDE, R. Neutral theory of quantitative genetic variance in as island model with local extinction and colonization. Evolution, v.46, p.381-389, 1992. 
LEE, S.W. Mating system perameters of Dryobalanops aromatica Gaertn. f. (Dipterocarpaceae) in three different forest types and a seed orchard. Heredity, v.32, p.338-345, 2000.

LEE, S.W.; WICKNESWARI, R.; MAHANI, M.C.; ZAKRI, A.H. Mating system parameters in a tropical tree species Shorea leprosula Miq. (Dipterocarpaceae), from Malaysian lowland dipterocarp forest. Biotropica, v.32, p.693-702, 2000.

LEWIS, P.O,; ZAYKIN, D. GDA - Genetic date analysis: Version 1.0(d12) for Windows. The University of New Mexico, Albuquerque, NM, 87131-1051, 1999.

LIENGSIRI, C.; YEH, F.C.; BOYLE, T.J.B. Isozyme analysis of a tropical forest tree, Pterocarpus Macrocarpus Kurz. in Thailand. Forest Ecology and Management, v.74, p.13-22, 1995.

LINDGREN, D.; LUIGI, D. G.; JEFFERSON, P. A. Status number for measuring genetic diversity. Forest Genetics, v.4, p.69-76, 1997.

LINHART, Y.B.; MITTON, J.B.; STURGEON, K.B.; DAVIS, M.L. Genetic variation in space and time in a population of ponderosa pine. Heredity, v.46, p.407-426, 1981.

LISBÃO JÚNIOR, J. Bracatinga como fonte energética. In.: SEMINÁRIO SOBRE ATUALIDADES E PERSPECTIVAS FLORESTAIS. "BRACATINGA: UMA ALTERnATIVA PARA O REFlORESTAMENTO”, 4., Curitiba, 1981. Anais. Curitiba: s. ed., 1981. p.133-43.

MILlAR, M.A.; BYRNE, M.; COATES, D.J.; STUKELY, M.J.C.; McCOM, J.A. Mating system studies in jarrah, Eucalyptus marginata (Myrtaceae). Australian Journal of Botany, v.48, p.475-479, 2000.

MILLER, M. Tools For Populations genetic analyses (TFPGA) 1.3: A windows program for analyses of allozyme and molecular population genetic data. (14 jan. 2004).

MINISTÉRIO DO MEIO AMBIENTE Biodiversidade brasileira. Brasília: MMA/SBF, 2002. 404p. 
MORAES, M.L.T. Variabilidade genética por isoenzimas e caracteres quantitativos em duas populações naturais de aroeira Myracrodruon urundeuva F.F. \& M.F. Allemão Anacardiaceae (Syn: Astronium urundeuva (Fr. Allemão) Engler. Piracicaba, 1992. 139 p. Tese (Doutorado) - Escola Superior de Agricultura "Luiz de Queiroz" Universidade de São Paulo.

MORAES, P.L.R.; MONTEIRO, R.; VENCOVSKY, R. Conservação genética de populações de Cryptocarya moschata Nees (Lauraceae) na Mata Atlântica do Estado de São Paulo. Revista Brasileira de Botânica, v.22, n.2, p.237-248, 1999.

MORAN, G.F.; MUONA, O.; BELL, J.C. Acacia mangium: a tropical Forest tree of the coastal lowlands with low genetic diversity. Evolution, v.43, n.1, p.231-235, 1989.

NAMKOONG, G. Inbreed effects on estimation of genetic additive variance. Forest Science, v.12, p.8-13, 1966.

NEI, M. Estimation of average heterozigosity and genetic distance from a small number of individuals. Genetics, v.89, p.583-590, 1978.

NIANG, A.; STYGER, E.; GAHAMANYI, A.; UGEZIWE, J. Mimosa scabrella: a tree for high places. Agroforestry Today, v.6, n.2, p.7, 1994.

PEGORADO, A.; CARPANEZZI, A.A. Avaliação do potencial melífero da bracatinga. Agrárias, v.14, n.1, p.167-172, 1995.

PEREIRA, J.C.D.; LAVORANTI, O.J. Comparação da qualidade da madeira de três procedências de Mimosa scabrella Benth. para fins energéticos. Boletim de Pesquisa Florestal, v.12, p.30-34, 1986.

PIRANI, J.R. (Coord.) Flores e abelhas em São Paulo. 2. ed. São Paulo: EDUSP, 1994. 192p.

POGGIANI, F.; CHIARANDA, R.; LAPA, R.P. Efeito do reflorestamento com Mimosa scabrella na recuperação do solo degradado pela exploração de xisto betuminoso. Silvicultura em São Paulo, v.16, p.1962-1970, 1982.

RAMALHO, M.A.P.; ABREU, A.F.B.; SANTOS, J.B. Melhoramento de espécies autógamas. In.: NASS, L.L.; VALOIS, A.C.C.; MELO, I.S.; VALADARESINGLIS, M.C. (Ed.) Recursos genéticos e melhoramento: plantas. Rondonópolis: Fundação MT, 2001. p.201-230. 
REITZ, R.; KLEIN, R.M.; REIS, A. Projeto madeira de Santa Catarina. Sellowia, n.28/30, p.3-320, 1978.

RESENDE, M.D.V.; HIGA, A.R. Maximização da eficiência de seleção em testes de progênies de Eucalyptus através da utilização de todos os efeitos do modelo matemático. Boletim de Pesquisa Florestal, v.28, n.29, p.37-55, 1994.

RESENDE, M.D.V.; STURION, J.A.; MENDES, S. Genética e melhoramento da erva-mate (Ilex paraguariensis St. Hil.). Colombo: Embrapa-CNPF, 1995. (Documentos, 25).

RITLAND, K.; JAIN, S. A model for the estimation of outcrossing rate and gene frequencies using independent loci. Heredity, v.47, p.35-52, 1981.

RITLAND, K. Correlated matings in the partial selfer Mimulus guttatus. Evolution, v.43, n.4, p.848-859, 1989.

RITLAND, K. Multilocus mating system program MLTR. Version 1.1. University of Toronto, Canada. 1997. (23 Mar. 2004).

ROCHA, O.J.R.; AGUILAR, G. Variation in the breeding behavior of the dry forest tree Enterolobium cyclocarpum (Guanacaste) in Costa Rica. Americam Journal of Botany, v.89, p.1600-1606, 2001.

ROTTA, E.; OLIVEIRA, Y.M.M. Área de distribuição natural da bracatinga (Mimosa scabrella Bentham). In.: SEMINÁRIO SOBRE ATUALIDADES E PERSPECTIVAS FLORESTAIS. "BRACATINGA: UMA ALTERNATIVA PARA O REFlORESTAMENTO”, 4., Curitiba, 1981. Anais. Curitiba: s. ed., 1981. p.1-23.

SAMPSON, J.F.; HOPPER, S.D.; JAMES, S.H. The mating system and population genetic structure in a bird-pollinated malle, Eucalyptus rhodantha. Heredity, v.63, p.383-393, 1989.

S.A.S. Institute Inc. SAS Procedures Guide. Version 8 (TSMO). SAS Institute Inc. Cary, N.C., 27513, USA, 2000. 
SCARDUA, F.P. Caracterização hidrológica de uma microbacia hodrográfica da Estação Experimental de Ciências Florestais de Itatinga, ESALQ/USP. Piracicaba, 1994. 94p. Dissertação (Mestrado) - Escola Superior de Agricultura "Luiz de Queiroz" - Universidade de São Paulo.

SCHIMIDT-ADAM, G.; YOUNG, A.G.; MURRAY, B.G. Low outcrossing rates and shift in pollinators in New Zealand Pohutukawa (Matrosideros excelsa; Myrtaceae). Americam Journal of Botany, v.87, n.9, p.1265-1267, 2000.

SEAONE, E; KAGEYAMA, P.Y.; SEBBENN, A.M. Efeitos da fragmentação florestal sobre a estrutura genética de populações de Esenbeckia leiocarpa. Scientia Forestalis, v.57, p.123-139, 2000.

SEOANE, C.E.C; SEBBENN, A.M.; KAGEYAMA, P.Y Sistema reprodutivo em populações de Esenbeckia leiocarpa. Revista do Instituto Florestal, v.13, n.1, p19-26, 2001.

SEBBENN, A.M. Estrutura genética de populações de jequitibá-rosa (Cariniana legalis (Mart.) O. Ktze.) por caracteres quantitativos e isoenzimáticos. Piracicaba, 2001. 210p. Tese (Doutorado) - Escola Superior de Agricultura "Luiz de Queiroz" Universidade de São Paulo.

SEBBENN, A.M. Número de árvores matrizes e conceitos genéticos na coleta de sementes para reflorestamentos com espécies nativas. Revista do Instituto Florestal, v.14, n.2, p.115-132, 2002.

SEBBENN, A.M. Número de populações para conservação genética in situ de espécies arbóreas. Revista do Instituto Florestal, v.15, n.1, p.45-51, 2003a.

SEBBENN, A.M. Tamanho amostral para conservação ex situ de espécies arbóreas com sistema misto de reprodução. Revista do Instituto Florestal, v.15, n.2, p.109-124, $2003 b$.

SEBBENN, A.M.; ETTORI, L.C. Conservação genética ex situ de Esenbeckia leiocarpa, Myracrodruon urundeuva e Peltophorum dubium em teste de progênies combinado. Revista do Instituto Florestal, v.13, n.2, p.201-211, 2001. 
SEBBENN, A.M.; KAGEYAMA, P.Y.; VENCOVSKY, R. Estrutura genética de subpopulações de Genipa americana L. (RUBIACEAE) em mata ciliar a partir de isoenzimas. Revista do Instituto Florestal, v.10, n.1, p.95-108, 1998a.

SEBBENN, A. M.; KAGEYAMA, P. Y.; VENCOSVKY, R. Variabilidade genética, sistema reprodutivo e estrutura genética espacial em Genipa americana L. através de marcadores isoenzimáticos. Scientia Forestalis, v.53, p.15-30, 1998b.

SEBBENN, A.M.; SIQUEIRA, A.C.M.F.; GURGEL GARRIDO, L.M.A. Interação progênies x locais e variabilidade genética em Jequitibá-Rosa - Cariniana legalis (Mart.) O. Ktze. Revista do Instituto Florestal, v.12, n.1, p.13-23, 2000 b.

SEBBENN, A.M.; KAGEYAMA, P.Y.; ZANATTO, A.C.S. Estrutura genética de populações de jequitibá-rosa (Cariniana legalis (Mart.) O. Ktze.) por caracteres quantitativos e isoenzimáticos. Revista do Instituto Florestal, v.13, n.2, p.121134, 2001a.

SEBBENN, A.M.; KAGEYAMA, P.Y.; ZANATTO, A.C.S. Estimativas de ganhos genéticos na seleção em populações de Cariniana legalis (Mart.) O. Ktze, incorporando informações do sistema misto de reprodução. Revista do Instituto Florestal, v.14, n.1, p.65-77, 2002a.

SEBBENN, A.M.; ZANATTO, A.C.S.; MORAES, E. Conservação dos recursos genéticos de Gallesia gorarema no Estado de São Paulo. Revista do Instituto Florestal, v.14, n. 2, p. 95-104, 2002b.

SEBBENN, A.M.; AOKI, H.; MORAES, M.L.T. Variação genética e seleção em teste de procedências de Grevillea robusta A.Cunn. Revista do Instituto Florestal, v.15, n.1, p.1-8, 2003c.

SEBBENN, A.M.; KAGEYAMA, P.Y.; SIQUEIRA, A.C.M.F.; ZANATTO, A.C. Taxa de cruzamento em populações de C. legalis (Mart.) O. Ktze. Scientia Forestalis, v.58, p.25-40, 2000a

SEBBENN, A.M.; SEOANE, C.E.S.; KAGEYAMA, P.Y.; LACERDA, C.M.B. Estrutura genética em populações de Tabebuia cassinoides: Implicações para o Manejo Florestal e a Conservaçao Genética. Revista do Instituto Florestal, v.13, n.2, p.93-113, $2001 b$. 
SEBBENN, A.M.; PONTINHA, A.A.; GIANOTTI, E.; KAGEYAMA, P.Y. Variação genética entre e dentro de procedências de Araucaria angustifolia no sul do Estado de São Paulo. Revista do Instituto Florestal, v.15, n.2, p.109-124, 2003a.

SEBBENN, A.M.; PONTINHA, A.A.; GIANOTTI, E.; KAGEYAMA, P.Y. Genetic variation in provenance-progeny test of Araucaria angustifolia in São Paulo state, Brazil. Silvae Genetica, v. 52, p. 181-184, 2003b.

SHAW, D.V. \& ALLARD, R.W. Estimation of outcrossing rates in Douglas-Fir using isozymes markers. Theoretical and Applied Genetics, v.62, p.113-120, 1982.

SHIMIZU, J.Y. Escolha de fontes de sementes de bracatinga para reflorestamento na região de Colombo. Boletim de Pesquisa Florestal, v.15, p.49-53, Dezembro, 1987.

SIQUEIRA, A.C.M.F.; SEBBENN, A.M.; KAGEYAMA, P.Y. \& ETTORI, L.C. Distribuição da variação genética entre e dentro de populações de Balfourodendron riedelianum (Engler) Engler para a conservação ex situ. Revista do Instituto Florestal, v.12, n.2, p.89-103, 2000.

SOUZA, A. P. Biologia molecular aplicada ao melhoramento. In.: NASS, L.L.; VALOIS, A.C.C.; MELO, I.S.; VALADARES-INGLIS, M.C. (Ed.) Recursos genéticos e melhoramento: plantas. Rondonópolis: Fundação MT, 2001. p.939966.

SOUZA, L.M.I.; SEBBENN, A.M.; KAGEYAMA, P.Y. Sistema de reprodução em Chorisia speciosa. Revista Brasileira de Botânica, v.26, n.113-121, 2003.

SOUZA JÚNIOR, C.L. Melhoramento de espécies alógamas. In.: NASS, L.L.; VALOIS, A.C.C.; MELO, I.S.; VALADARES-INGLIS, M.C. (Ed.) Recursos genéticos e melhoramento: plantas. Rondonópolis: Fundação MT, 2001. p.159200.

SQUILLACE, A.E. Average genetic correlations among offspring from open-pollinated forest trees. Silvae Genetica, v.23, p.149-156, 1974.

SURLES, S.E.; ARNOLD, J.; SCHNABEL, A.; HAMRICK, J.L.; BONGARTEN, B.C. Genetic relatedness in open-pollinated families of two leguminous tree species, 
Robinia pseudoacacia L. and Gleditsia triacanthos L. Theorical and Applied Genetics, v.80, p.49-56, 1990.

SWOFFORD, D.L.; SELANDER, R.B. Biosys-1. A FORTRAN computer program for the analysis of allelic variation in population genetics and biochemical systematics. Journal of Heredity, v.72, p.282-283, 1989.

TELLES, M.P.C.; VALVA, F.D.; BANDEIRA, L.F.; COELHO, A.S.G. Caracterização genética de populações naturais de araticunzeiro (Annona crassiflora Mart. Annonaceae) no Estado de Goiás. Revista Brasileira de Botânica, v.26, n.1, p.123-129, 2003.

TELLES, M.P.C.; SILVA, R.S.M.; CHAVES, L.J.; COELHO, A.G.; DINIZ FILHO, J.A.F. Divergência entre subpopulações de cagaiteira (Eugenia dysenterica) em resposta a padrões edáficos e distribuição espacial. Pesquisa Agropecuária Brasileira, v.36, n.11, p.1387-1394, 2001.

TORGGLER, M.G.F.; CONTEL, E.P.B.; TORGGLER, S.P. Isoenzimas: variabilidade genética em plantas. Ribeirão Preto: Sociedade Brasileira de Genética, 1995. 186p.

VALOIS, A. C.; SALOMÃO, A. N.; ALLEM, A. C. (Org.) Glossário de recursos genéticos vegetais. Brasília: Embraoa - SPI, $1996 . \quad 62 p$. (EMBRAPA/CENARGEN).

VENCOVSKY, R.; BARRIGA, P. Genética biométrica no fitomelhoramento. Ribeirão Preto: Revista Brasileira de Genética, 1992. 496p.

VENCOVSKY, R.; PEREIRA, M.B.; CRISÓSTOMO, J.R.; FERREIRA, M.A.J.F. Genética e melhoramento de populações mistas. In.: NASS, L.L.; VALOIS, A.C.C.; MELO, I.S.; VALADARES-INGLIS, M.C. (Ed.) Recursos genéticos e melhoramento: plantas. Rondonópolis: Fundação MT, 2001. p.231-282.

WEIR, B.S.; COCKERHAM, C.C. Estimating F-statistics for the analysis of population structure. Evolution, v.38, p.1358-1370, 1984.

WEIR, B.S. Genetic data analysis II. Methods for discrete population genetic data. North Caroline State University, Sinauer Ass. Inc. Pub., Massachusets, 1996. 445p. WRIGHT, S. Systems of mating. Genetics, v.6, p.111-178, 1921. 
WRIGHT, S. Evolution and genetics populations. Annual Eugenic, v.15, p.323-354, 1951.

WRIGHT, J.W. A simplified design for combined prevenance and progeny testing. Silvae Genetica, v.27, n.2, p.68-70, 1978.

YANG, R.C.; YEH, F.C.; YANCHUK, A.D. A comparison of Isozymes and quantitative genetic variation in Pinus contorta spp. latifolia by $F_{S T}$. Genetics, v.142, p.1045-1052, 1996.

ZHENG, Y.O.; ENNOS, R.; WANG, H.R. Provenance variation and genetic parameters in a trial of Pinus caribaea Morrelet var. bahamensis and Golf. Forest Genetics, v.3, n.1, p.165-174, 1994.

ZOBEL, B.; TALBERT, J. Applied forest tree improvement. USA:North Carolina State University, 1984. 496 p.

ZUCCHI, M.I.; BRONDANI, R.P.V.; PINHEIRO, J.B.; CHAVES, L.J.; COELHO, A.S.G.; VENCOVSKI, R. Genetic structure and gene flow in Eugenia dysenterica DC in the Brazilian Cerrado utilizing SSR markers. Genetic and Molecular Biology, v.26, n.4., p.449-457, 2003. 